University of Louisville

ThinkIR: The University of Louisville's Institutional Repository

Electronic Theses and Dissertations

$5-2014$

\title{
The role of pesticides in non-alcoholic fatty liver disease (NAFLD).
}

Laila Al-Eryani 1986-

University of Louisville

Follow this and additional works at: https://ir.library.louisville.edu/etd

Part of the Pharmacy and Pharmaceutical Sciences Commons

\section{Recommended Citation}

Al-Eryani, Laila 1986-, "The role of pesticides in non-alcoholic fatty liver disease (NAFLD)." (2014).

Electronic Theses and Dissertations. Paper 27.

https://doi.org/10.18297/etd/27

This Master's Thesis is brought to you for free and open access by ThinkIR: The University of Louisville's Institutional Repository. It has been accepted for inclusion in Electronic Theses and Dissertations by an authorized administrator of ThinkIR: The University of Louisville's Institutional Repository. This title appears here courtesy of the author, who has retained all other copyrights. For more information, please contact thinkir@louisville.edu. 


\title{
THE ROLE OF PESTICIDES IN NON-ALCOHOLIC FATTY LIVER DISEASE (NAFLD)
}

\author{
By \\ Laila Al-Eryani \\ A Thesis Submitted \\ To The Faculty of the School \\ Of Medicine of the University Of Louisville \\ In Partial Fulfillment of the Requirements \\ For The Degree Of \\ Master of Science \\ Department Of Pharmacology and Toxicology \\ University Of Louisville \\ Louisville, Kentucky
}

May 2014 



\title{
THE ROLE OF PESTICIDES IN NON-ALCOHOLIC FATTY LIVER DISEASE (NAFLD)
}

\author{
By \\ Laila AI-Eryani \\ Thesis approved on \\ April 03, 2014 \\ By the following Thesis Committee:
}

Matthew C. Cave, M.D.

Russell A. Prough, Ph.D.

J. Christopher States, Ph.D. 


\section{ACKNOWLEDGMENTS}

I sincerely thank my mentor Dr. Matt Cave and I would like also to express my deepest gratitude to Dr. Cam Falkner and my lab-mates Banrida Wahlang and Heather Clair for their guidance, motivation, patience and persistent help through my master's research work and thesis writing. Special thanks to my committee members for their guidance and the Fulbright program for giving me this chance to pursue my graduate studies. Last but not least I am very thankful to my family and friends for their continuous support. 


\title{
ABSTRACT \\ THE ROLE OF PESTICIDES IN NON-ALCOHOLIC FATTY LIVER DISEASE (NAFLD)
}

\author{
Laila Al-Eryani
}

\section{April 03, 2014}

NAFLD, the most common form of liver disease worldwide, is caused by various factors including industrial chemicals and pesticides exposure. Annually, 5.2 billion pounds of pesticides are used worldwide and can contribute to liver disease, but their role is modestly studied. We hypothesize that pesticides contaminating food supply can worsen diet-induced steatosis via xenobiotic receptor activation. Two human and two rodent databases were utilized and $85 \%$ of the 330 chemicals identified associated with NAFLD were pesticides. Eight were selected for evaluating hepatic receptor activation in vitro. The majority including DDT activated $\mathrm{hPXR} / \mathrm{CAR}$ and $\mathrm{mPXR}$. DDT (100 mg/kg) was studied in vivo in a diet-induced obesity (DIO) model. DDT upregulated Cyp2b10 (CAR target) in control diet-fed mice. DDT decreased adiposity, but it did not affect weight gain, food consumption or insulin resistance. In conclusion, DDT improved steatosis, but it did not affect NAFLD, obesity, liver damage or diabetes caused by DIO. 


\section{TABLE OF CONTENTS}

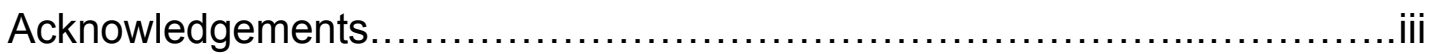

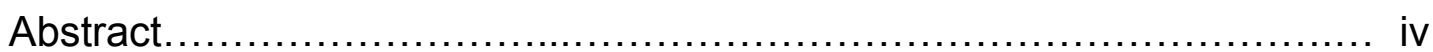

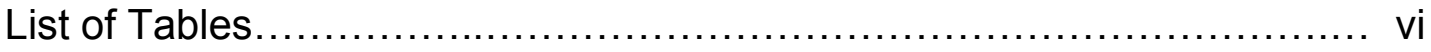

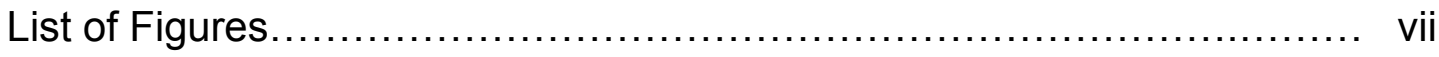

Chapter 1: Introduction.................................................. 1

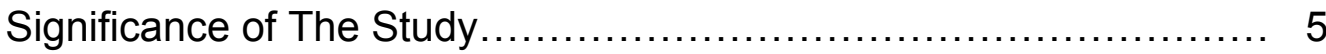

Chapter 2: Identification of Chemicals Associated With NAFLD ........... 7 Introduction......................................................... 7

Materials and Methods ............................................. 9

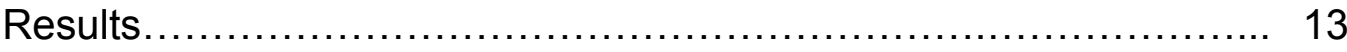

Discussion............................................................. 16

Chapter 3: Activation of Hepatic Xenobiotic Receptors by Pesticides........ 18

Introduction......................................................... 18

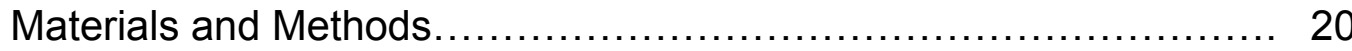

Results.................................................................. 25

Discussion............................................................. 35

Chapter 4: DDT Did Not Worsen NAFLD In Diet Induced Obesity Model... 37

Introduction........................................................ 37

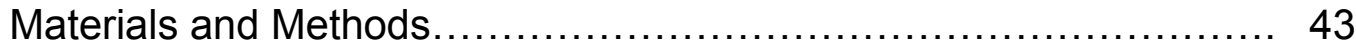

Results............................................................ 46

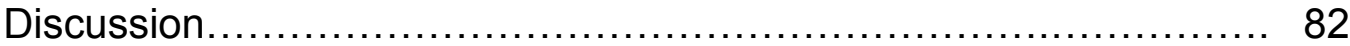

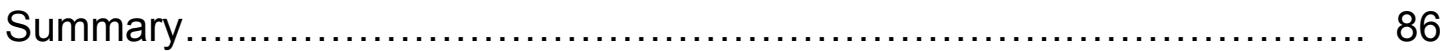

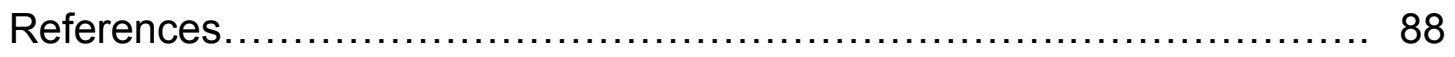

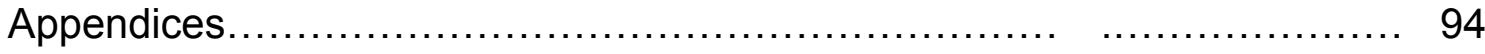

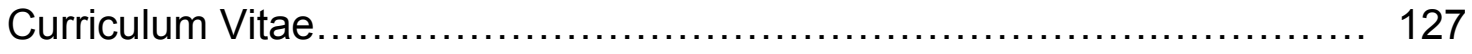




\section{LIST OF TABLES}

Table 1. Mutual chemicals between NHANES, ToxCastDB, ToxRefDB and CEBS database ............................................ 26

Table 2. Summary of results of the transient transfection assays.......... 34 


\section{LIST OF FIGURES}

Figure 1: Activation of $\mathrm{hPXR}$ by pesticides.............................. 28

Figure 2: Activation of mPXR by pesticides............................. 29

Figure 3: Activation of hCAR2 by pesticides............................. 30

Figure 4: Activation of mCAR by pesticides................................ 31

Figure 5: Concentration response curve of $\mathrm{hPXR}$ activation by DDT........ 32

Figure 6: Concentration response curve of $\mathrm{hPXR}$ activation by DDE........ 33

Figure 7: Lipid-adjusted serum levels of organochlorine compounds........ 38

Figure 8: DDT did not affect body weight in either CD- or HFD-fed mice.... 47

Figure 9: DDT did not affect food consumption in either CD- or HFD-fed 48 m: DDT decreased fat tissue weight in both CD- and HFD-fed

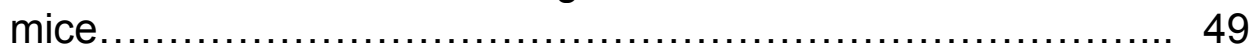

Figure 11: Neither DDT nor HFD affected the lean tissue weight............ 50

Figure 12: DDT did not affect the epididymal weight per body weight ratio in CD- and HFD-fed mice.........................................

Figure 13: DDT decreased the liver weight per body weight ratio in HFDfed mice. ....................................................... 52

Figure 14: DDT decreased ALT levels in CD and HFD animals............. 54

Figure 15: Neither DDT nor HFD affected AST plasma levels............... 55

Figure 16: H\&E staining of liver tissues.................................. 56

Figure 17: DDT did not affect GTT in either CD- or HFD-fed mice........... 58

Figure 18: DDT did not affect fasting blood glucose levels................. 59 
Figure 19: Neither DDT nor HFD affected plasma resistin levels.............60 60

Figure 20: DDT did not affect plasma levels of leptin...................... 61

Figure 21: DDT exposure increased plasma levels of adiponectin in CDand HFD- fed mice................................................. 62

Figure 22: DDT did not affect total cholesterol plasma levels................ 64

Figure 23: DDT did not affect the plasma levels of HDL................... 65

Figure 24: DDT did not affect triglycerides plasma levels................... 66

Figure 25: DDT did not affect IL-6 plasma levels........................... 67

Figure 26: DDT did not affect hepatic IL-6 expression.................... 68

Figure 27: DDT decreased plasma levels of tPAl-1 ...................... 69

Figure 28: Neither HFD nor DDT affected the TNFa hepatic expression.... 70

Figure 29: Neither HFD nor DDT affected TNFa plasma levels............. 71

Figure 30: Neither HFD nor DDT affected MCP-1 plasma levels............ 72

Figure 31: Neither HFD nor DDT affected hepatic MCP-2 expression........ 73

Figure 32: DDT decreased the hepatic expression of CPT1a in both CDand HFD- fed groups......................................... 75

Figure 33: DDT decreased the hepatic expression of Cyp4a10 in both CD- and HFD- fed groups.................................... 76

Figure 34: HFD decreased the hepatic expression of FAS ................. 77

Figure 35: DDT and HFD increased the hepatic expression of CD36 ........ 78

Figure 36: DDT and HFD increased the hepatic expression of Cyp2b10... 80

Figure 37: HFD increased the hepatic expression of Cyp3a11 .............. 


\section{CHAPTER 1}

\section{INTRODUCTION}

\section{Pesticides:}

In our daily lives, we are exposed to a variety of chemicals, many of which are pesticides, through food consumption or contact with skin and air. According to the United States Environmental Protection Agency (US EPA), a pesticide is defined as "any substance or mixture of substances intended for preventing, destroying, repelling, or mitigating any pest". Although pesticides are often restricted to insecticides, the term 'pesticide' also applies to herbicides, fungicides, and various other substances used for controlling pests (1). Pesticide usage is a double-edged sword; they are valuable for controlling pests, but they are also poisonous compounds to humans and animals. Many of these compounds are lipophilic and tend to accumulate in the adipose tissue. However, the body defense mechanism, particularly the liver, is responsible for the detoxification of these xenobiotic compounds through metabolism by cytochrome P450 enzymes, including CYP3A and CYP2B families $(2,3)$. In contrast, if the pesticides' bioaccumulated concentration reaches lethal levels due to high dose or chronic exposure, they can overwhelm the liver detoxification capacity and cause toxicity. In fact, the WHO reported that at least 3 million cases of pesticide poisoning occur worldwide annually. Furthermore, many pesticides have been 
associated with liver disease and elevated levels of liver enzymes (aminotransferases) (4).

Chemical pesticides are classified into four main classes: organophosphate, carbamate, organochlorine and pyrethroid pesticides (5). Our laboratory works with persistent organic pollutants (POPs) including polychlorinated biphenyls (PCBs) and organochlorine pesticides (OCPs) and their association with liver disease. Epidemiological studies have demonstrated associations between pesticides such as OCPs and toxicant associated steatohepatitis (TASH)/nonalcoholic fatty liver disease (NAFLD) as well as serum alanine aminotransferase (ALT) elevation (6). However, the mechanisms by which these compounds potentiate liver disease and damage are poorly studied.

Nonalcoholic fatty liver disease (NAFLD) is the most prevalent form of liver disease worldwide (7-9). It is often associated with obesity, insulin resistance, diabetes and other metabolic disorders primarily through adipocytokine dysregulation and hence, NAFLD is considered a hepatic indicator of the metabolic syndrome $(10,11)$. Histopathologically, NAFLD involves a wide spectrum of liver damage, initiating from steatosis, which is characterized by fatty liver, and transforming to steatohepatitis $(12,13)$. Our laboratory focuses specifically on nonalcoholic steatohepatitis (NASH), which progresses in a "two hit" model (8). The first hit results in steatosis, an accumulation of macrovesicular or microvesicular triglyceride in at least $5 \%$ of hepatic cells, and this can be brought about by excessive consumption of hyper-caloric diets such as highfructose diet $(9,14,15)$. The "second hit" results in hepatic and systemic 
inflammation which is accompanied by increased levels of inflammatory cytokines/adipokines, mitochondrial dysfunction and oxidative stress and causes steatohepatitis and fibrosis $(13,16)$. Steatohepatitis may then progress to fibrosis and cirrhosis (4). The "second hit" can include factors such as industrial chemicals and toxic pollutants leading to the term "toxicant associated steatohepatitis" (TASH) $(17,18)$. We focus on the role of environmental pollutants as a 'second hit' in NAFLD and the mechanisms of their action in the potentiation and progression of steatohepatitis.

TASH was first described in vinyl chloride (VC) workers who reported increased levels of proinflammatory cytokines, insulin resistance, and antioxidant depletion $(17,18)$. The necrotic hepatocyte death biomarker, cytokeratin 18 , was also elevated in these workers $(11,19)$. Mild to moderate ALT and aspartate aminotransferase (AST) elevation are the only laboratory manifestations reported in most cases of steatohepatitis $(14,18,20,21)$. However, the VC workers with TASH had normal serum ALT and AST levels. On the other hand, abnormalities in ALT and AST levels have been reported in humans and animals exposed to other chemicals such as carbon tetrachloride, dimethylformamide, some minerals and pesticides (22).

Xenobiotic compounds are metabolized by P450 enzymes, which are under the control of xenobiotic receptors, and this metabolic link can add a layer of complexity to both the disease and treatment state. Hepatic xenobiotic receptors, particularly the pregnane xenobiotic receptor (PXR) and the constitutive androstane receptor (CAR), play an important role in xenobiotic 
metabolism. Apart from regulating detoxification, PXR has been reported to promote lipogenesis and repress fatty acid- $\beta$-oxidation leading to hepatic lipid accumulation $(23,24)$. On the other hand, CAR reportedly suppresses gluconeogenesis and lipid metabolism and decreases serum triglyceride levels (24). Hence both PXR and CAR appear to play a pivotal role in regulating energy metabolism and their activation/inhibition can lead to NAFLD, obesity and the metabolic syndrome (24). In addition to CAR and PXR, other nuclear receptors such as the peroxisome proliferator-activated receptors (PPARs) regulate genes associated with glucose and lipid metabolism, adipogenesis, insulin sensitivity, cell growth, and differentiation $(25,26)$. Their activation also affects immune responses and energy homeostasis. In fact, PPARs are important therapeutic targets in treating metabolic disorders such as diabetes (25). The thiazolidinedione drugs, which are PPARY agonists are used for treating type 2 diabetes, whereas another type 2 drug, metformin, works via PPARa-dependent or independent mechanisms $(26,27)$. Similar to the PPARs, the farnesoid $X$ receptor (FXR), plays an important role in regulating metabolism of bile acids, fat, cholesterol, glucose and xenobiotics (28). In fact, clinical trials on FXR-targeting drugs for treating cholestasis, type 2 diabetes mellitus, NASH or NAFLD and primary bile acid diarrhea are now in Phase I and II trials (28). 


\section{Significance of The Study:}

Non-alcoholic fatty liver disease (NAFLD) is prevalent in $30 \%$ of the US adult population and it is the leading cause of chronic liver disease worldwide (7, 8, 29). According to a community-based study, NAFLD increases the mortality risk among the US population (7). NAFLD was associated with obesity, insulin resistance, diabetes and other metabolic disorders $(10,11)$. In one study, $100 \%$ of obese diabetic patients had steatosis, $50 \%$ of those had steatohepatitis and $19 \%$ had cirrhosis (30). Furthermore, many industrial chemicals including pesticides have been associated with fatty liver disease.

Elevated serum ALT and AST are traditional biomarkers of NAFLD (4). Abnormalities in ALT and AST were found in humans and animals exposed to OCPs and other chemicals such as carbon tetrachloride, dimethylformamide, minerals and pesticides $(4,22)$. Because traditional NAFLD biomarkers are not effective in diagnosing TASH, liver biopsies serve as a good diagnostic tool. However, obtaining human liver biopsies can be challenging, therefore, animal models can be a valuable tool in identifying TASH-causing chemicals. Furthermore, the concentration(s) needed and mechanism(s) exhibited by pesticides in their contribution to NAFLD are modestly studied due to the lack of disease manifestations and chemical indicators. Additionally, a comprehensive list of these chemicals is not currently available in literature.

Pesticide exposure and their biological effects are relevant because annual pesticide consumption worldwide was 5.2 billion pounds, out of which 1.1 billion pounds was consumed in the US alone (31). While a large number of 
pesticides have been banned in many countries including the US, some still exist in the environment due to their thermodynamic stability and lipophilicity.

The hepatic xenobiotic receptors such as CAR and PXR play an important role in both xenobiotic detoxification and endobiotic metabolism either through direct activation or interaction with other receptors (24). Therefore, elucidating the mode(s) of action of pesticides through CAR and PXR regulation is crucial in terms of NAFLD due to their role in maintaining energy homeostasis $(23,24)$.

Based on the evidence provided, we hypothesize that pesticides, which contaminate the food supply, may worsen diet-induced steatohepatitis via xenobiotic receptor activation, PXR and CAR. Therefore, to test our hypothesis, 1) we identified pesticides associated with steatohepatitis and NAFLD in a) rodent studies (ToxRefDB and CEBS) and b) human studies (NHANES). 2) We identified pesticides activating PXR and CAR in humans a) via data-screening of ToxCastDB database and b) screening assays using HepG2 cells. 3) After screening a list of pesticides, which were associated with NAFLD and activated PXR and CAR, we selected DDT, a relevant POPs, to be studied in vivo in a dietinduced obesity (DIO) model. 


\section{CHAPTER 2 \\ IDENTIFICATION OF CHEMICALS ASSOCIATED WITH NAFLD INTRODUCTION}

The liver is the first-line of defense against potentially harmful xenobiotics, and it is therefore not surprising that it is also the target organ that is most commonly affected by industrial chemicals (4). Indeed, 33\% of the 677 most common workplace chemicals reported in the National Institute of Occupational Safety and Health Pocket Guide are associated with hepatotoxicity (32). The pathologic liver lesions associated with chemical exposures are myriad and range from hepatitis to fibrosis and cirrhosis with liver cancer (22). However, following the description of TASH, it now appears that fatty liver may be the most common pathologic response to chemicals $(4,20,22,33,34)$.

Recent terms describing fatty liver disease such as "steatosis" and "steatohepatitis" were not well-known before recognizing fatty liver disease as a clinical disease. Consequently, one of the tools used to identify compounds relevant to liver disease, is to search former chemical studies by looking at fatty liver clinical and histopathological biomarkers. With NAFLD, the only clinical biomarker for fatty liver disease is serum ALT elevation. However, diagnosing TASH in humans is challenging for several reasons, namely, the entity is 
clinically under-recognized and routine clinical biomarkers are insensitive. Also, out of the 83 million substances and 65 million sequences registered by the chemical abstracts service by 2014 , there is no comprehensive list of chemicals that cause TASH (35). As such, TASH is a clinicopathologic diagnosis that relies solely on histologic examination.

The transition from steatosis to steatohepatitis is characterized by centrilobular (zone 3) centered injury and lobular inflammation (lymphocytes with neutrophils and activated Kupffer cells), hepatocyte ballooning and Mallory-Denk bodies and fibrosis (36). While these findings are typically present in hemotoxylin and eosin (H\&E) stained slides, other stains such as Oil-Red-O that stains microvesicular lipid droplets are used to quantify steatosis. Similar pathologic lesions have been observed in human NAFLD/TASH and in rodent models of steatohepatitis (4).

The purpose of this part of the study is to identify chemicals associated with the development of hepatic steatosis in previously published human and rodent studies. Searchable archive of Human studies from the 2003-2004 NHANES (National Center for Health Statistics) and rodent studies provided in the websites of US Environmental Protection agency (EPA) and the National Institute of Environmental Health Sciences (NIEHS) presented a unique opportunity to accomplish this objective. The identification of environmental chemicals associated with the development of hepatic steatosis/TASH will enable subsequent mechanistic animal studies and clinical translation in exposed humans. 


\section{MATERIALS AND METHODS}

\section{Data-screening:}

The first database screened was the 2003-2004 National Health and Nutrition Examination Survey of the United States population (NHANES 20032004). The NHANES was evaluated in a cross-sectional cohort study done previously by our group. The National Center for Health Statistics (NCHS) conducts the NHANES as a complex multistage probability sample, and interprets the health and nutrition findings as representative of the noninstitutionalized U.S. civilian population (37). Approval for the analysis of the NHANES data was granted by the University of Louisville Institutional Review Board. The following exclusion criteria were used in the study: age $<18$ years, positive serum hepatitis $B$ surface antigen, positive serum hepatitis $C$ antibody, elevated transferrin saturation ( $>60 \%$ for men and $>50 \%$ for women), and alcohol consumption $\geq 20 \mathrm{~g} /$ day for men and $\geq 10 \mathrm{~g} /$ day for women. As classified by the NCHS, the downloaded pollutants data posted prior to December 2008 showed 196 pollutants from 17 subclasses (38). All alanine aminotransferase (ALT) and pollutant levels were measured for each participant and 111 of 196 pollutants were evaluated (38). Elevated ALT was defined as proposed by Prati et al. (>30 IU/L for men and $>19 \mathrm{IU} / \mathrm{L}$ for women) $(38,39)$. Subjects were classified into different quartiles for each class of pollutants, with the first quartile composed of subjects with the lowest serum levels of each pollutant. Pollutants within the same subclass were then summed by their ranks depending on the 
magnitude of their detectable levels, because of the likelihood of an individual's exposure to more than one pollutant in the same subclass (38). Multivariateadjusted odds ratios for ALT elevation were measured though the increasing quartiles of chemical exposure and the $1^{\text {st }}$ quartile was used as the reference group (38).

Two more sets of rodent databases compiled by the federal government for environmental chemicals were used in this study. The former was the Environmental Protection Agency (EPA) database known as ToxRefDB or the Toxicological Reference Database, which was designed by the National Center for Computational Toxicology (NCCT) and Environmental Protection Agency's (EPA) office of Pesticide programs (OPP). This database includes pesticide registration toxicity data for the past 30 years and $\$ 2$ billion of animal studies results $(40,41)$. Using standardized vocabulary, ToxRefDB warehouses detailed study design, dosing, and observed treatment-related effects (41). The ToxRefDB stores also chemical toxicity data in detail in free accessible and searchable databases (41). ToxRefDB also connects with the ACToR (Aggregated Computational Toxicology Resource) in order to link it with public hazard, exposure and risk resources (41). Furthermore, ToxRefDB is connected to the ToxCast, another EPA chemical screening tool used to understand biological processes affected by chemicals (41). The available ToxRefDB database allows aggregation and grouping of chemicals depending on the toxicological outcomes that are specific to the type of the study and target organ/effect categories (e.g., tumorigenicity) (42). ToxRefDB classifies chemicals 
by their relative potency depending on specific endpoints and also assigns groups based on the mechanism of action (42). Future improvements of the ToxRefDB are planned, which will connect the relational environment of ToxRefDB with associated chemical structure information (43). Furthermore, searching will develop predictive high-through-put screening bioactivity profiles and genomic signatures (16). Currently, ToxRefDB warehouses searchable pathologic information on 474 studies of pesticides and intermediates. In our study, the $474 \mathrm{rat} /$ mouse studies were queried for histological NAFLD and TASH descriptors including "fatty change", "Oil red O positive", "steatosis", and "lipid deposition". The data were accessed in Fall 2013 at http://actor.epa.gov/toxrefdb/faces/Home.jsp. The following study types were queried: sub-chronic (SUB), chronic ( $\mathrm{CHR}$ ) and multigeneration reproductive (MGR) in both rat and mouse species. The effect type selected was "pathology (non-neoplastic)". The effect target was always the "liver" in the search and the effect descriptions were: "fatty change", "lipid deposition", "steatosis" and "Oil red O" positivity in increased effect direction. Compound selection was based on the altered NAFLD and TASH descriptors at the Lowest Effect Level (LEL). Compounds and their LELs were arranged and listed in tables (Appx. 1).

The latter rodent database was the Chemical Effects in Biological Systems (CEBS) data repository developed by the National Toxicology Program (NTP) and it warehouses about 9000 rodent toxicology studies (44). CEBS combines public toxicogenomics databases such as the study design and timeline, clinical chemistry and histopathology, microarray and proteomics data 
(45). CEBS warehouses data from academic, industrial and governmental laboratories and it was mainly developed to allow public and free search though the results of these studies $(45,46)$. CEBS stores rats, mice and human subjects studies and it contains more than 4000 microarray hybridizations, and $752 \mathrm{D}$ gel images with details protein identification (45). Furthermore, CEBS contains the clinical chemistry and histopathology data from more than 1500 animals (45). CEBS was accessed at: http://cebs.niehs.nih.gov. The queried assay domain was "histopathology" and the diagnoses selected were "fatty change" and "toxic hepatopathy" as the latter two terms appear to have been used to describe fatty liver in several National Toxicology Program (NTP) reports on polychlorinated biphenyls (47). "Liver and all its parts" was always the target organ selected and all degrees of severity were included. The search initially returned 329 studies, but medications and natural products were subsequently manually excluded. Remaining compounds and their LELs were then arranged and listed in tables in the CEBS databases (Appx. 1-7). 


\section{RESULTS}

\section{NHANES 2003-2004:}

Eight organochlorine pesticides were detected in the serum of the participants of the survey and three of them, trans-nonachlor, heptachlor epoxide and dieldrin, showed increased odds ratios for ALT elevation across quartiles ( $p$ trend-adj 50.05). The other five pesticides, namely, oxychlordane, hexachlorobenzene, hexachlorocyclohexane, dichlorodiphenyldichloroethylene (DDE) and dichlorodiphenyltrichloroethane (DDT) showed a trend towards significance when we compared the 4 th quartile vs. unexposed $(95 \% \mathrm{Cl})$. In the 4th quartile, DDE had the highest median lipid-adjusted serum concentration (1535 ng/g) of the eight analyzed pesticides (Appx. 1). 


\section{ToxRefDB}

At the Lowest Effect Level (LEL), 42 unique pesticides from 474 pesticides

were associated with steatosis/TASH pathologic descriptors including "fatty change", "Oil red O positive", "steatosis", and "lipid deposition". The 42 compounds included 22 fungicides, 13 herbicides, 6 insecticides, and 1 miticide which are given in Appendix 2, along with study design, species, and LEL values. These positive results came from both species (rat $=40$ and, mouse $=20$ ) from all queried study designs including sub-chronic $(n=16)$, chronic $(n=34)$ and multigeneration reproductive $(n=10)$. Thus, nearly $10 \%$ of ToxRefDB pesticide studies were associated with the development of steatosis based on the use of TASH descriptors. It is possible that, due to the high LEL values associated with some reported liver disease descriptors, only a subset of these pesticides are consequential to human disease at relevant environmental exposures. However, 6 pesticides had LELs less than $10 \mathrm{mg} / \mathrm{kg} / \mathrm{day}$, and that increases the likelihood that they could be significant mediators of TASH depending on their crop application patterns. These pesticides were: cyproconazole, dazomet, fluazinam, hexaconazole, pyrasulfotole metabolite (SXX 0665) and acequinocyl. Cyproconazole, dazomet, fluazinam, flusilazole, hexaconazole, paclobutrazol, triadimefon, vinclozolin and fluthiacet-methyl pesticides were associated with the development of steatosis in more than one study in the ToxRefDB database. This reproducibility increases the likelihood that exposures to these chemicals do indeed result in TASH. Two fungicides, dazomet and hexaconazole, were linked to steatosis in 3 studies and had LELs less than 10 in at least 2 studies. 


\section{CEBS:}

Three hundred twenty nine studies of 81 chemicals reported positive steatosis/TASH descriptors ("toxic hepatopathy" and "fatty change"). These chemicals included 31 solvents, plasticizers, monomers, and chemical intermediates (Appx. 3), 14 miscellaneous chemicals (Appx. 4), 12 pesticides and pesticide intermediates (Appx. 5), 9 fragrances, cosmetics and essential oils (Appx. 6), 9 paints, polishes, dyes and food additives (Appx. 7), and 6 PCBs and dioxin-like compounds (Appx.8). Chemical name, study design, species and LEL values, when known, are provided. Several chemicals from each class produced steatosis with LELs $\leq 10 \mathrm{mg} / \mathrm{kg}$ (7/14 pesticides; 6/6 PCBs and dioxin-like compounds; 4/31 solvents, plasticizers, monomers, and chemical intermediates; 3/9 paints, polishes, and dyes; $3 / 14$ miscellaneous chemicals; and 1/9 fragrances; cosmetics, and essential oils). In CEBS, steatosis was reported in 29, mice studies and 57 rat studies, short term $(n=9)$ and chronic $(n=72)$. 


\section{DISCUSSION}

In the 2003-2004 NHANES population, an unexpected increase in the adjusted odds ratios for ALT elevation was observed in many of the participants. ALT levels were the highest in participants with very high serum levels of some metals and eight OCPs. Interestingly, among the quartile with the highest ALT elevation, the DDE median lipid-adjusted serum concentration was also the highest (1535 ng/g) supporting our decision to use DDT and DDE in further studies. Along with other compounds in the survey, DDT and OCPs are still persistent in the environment. For example, the Blackleaf Chemical site in

Louisville, Kentucky was reported by the US EPA and the Kentucky Department of Environmental Protection to be contaminated with dieldrin, other OCPs and metals such as lead and arsenic $(48,49)$.

Between CEBS and ToxRefDB, 371 studies linked 123 unique environmental chemicals to fatty liver disease in rodents. Pesticides comprised almost $44 \%(54 / 123)$ of these chemicals and $14 / 55$ pesticides led to steatosis with LELs less than 10. While it is not surprising that insecticides were on the list; fungicides and herbicides may be under-recognized mediators of TASH. Fungicides and herbicides are widely used at farms, houses and industry (50). According to the EPA, annual fungicide consumption worldwide is almost 500 million pounds (50). Some fungicides such as the conazoles have been associated with hepatotoxicity and hepatomegaly in rats (51). Furthermore, triadimefon and propiconazole are conazole fungicides that emerged from the 
ToxRefDB analysis and they have been reported to induce hepatotoxicity and hepatomegaly (51). Cyproconazole is another fungicide in the ToxRefDB list which is found to cause hepatomegaly, single-cell necrosis and fat vacuolation leading to liver damage (52). Moreover, herbicides are widely used in the United States. Herbicides are mainly classified into: chlorophenoxy, bipyridil, triazine and chloroacetanilide which are also associated in causing or worsening liver disease (22). Many of the herbicides from our study do not belong to the previously mentioned classes providing researchers new targets for studying liver disease. Interestingly, of all pesticides dazomet and hexaconazole were linked with fatty liver disease by relatively low LELs in multiple studies. Dazomet is a fungicide, herbicide and nematicide that causes hepatomegaly combined with large fat droplets due to intermediary- and centro-acinary fatty degeneration in mice and it is also associated with liver damage in long term exposure $(53,54)$. Hexaconazole is a systemic triazole fungicide mainly used for control of black and yellow sigatoka diseases in bananas (55). Hexaconazole was found to be associated with hepatic enzyme elevation, hepatocellular hypertrophy, hepatic fatty infiltration and fatty changes in rodent and dog studies (55). While it is not surprising that subacute/chronic pesticide exposures resulted in steatosis, it was surprising that 10 multigenerational reproductive studies reported a positive effect. Additionally, this may be the first evidence linking developmental pesticide exposures to fatty liver disease. 


\section{CHAPTER 3}

\section{ACTIVATION OF HEPATIC XENOBIOTIC RECEPTORS BY PESTICIDES INTRODUCTION}

PXR and CAR were traditionally thought to be xenobiotic detoxification receptors but recent studies have demonstrated their roles in glucose and lipid metabolism $(24,56)$. PXR and CAR also share common ligands and have overlapping target gene battery (24). Identifying pesticides that can activate CAR and/or PXR is crucial because this can be one of the mechanism(s) by which pesticide can exposure cause hepatic fatty infiltration and damage as seen in studies in CEBS/ToxRefDB databases. Previous work by our laboratory group demonstrated that PCB 153, a known CAR activator, worsened DIO and therefore supported the hypothesis that these compounds can also worsen NAFLD and DIO through nuclear receptor interaction.

The ToxCastDB database contains results of high throughput assays that test the effect of pesticides on human and rodent receptor activation and target gene induction at different doses. Therefore, this database was used to identify pesticides that activate CAR and PXR. Furthermore, after identifying pesticides associated with NAFLD from the database-screening mentioned in the first part of the study, we selected eight pesticides to test for CAR and PXR activation in 
vitro. The results from this study, supported by information obtained from the ToxCastDB, will allow us to predict the effect of these chemicals in humans. 


\section{MATERIALS AND METHODS:}

\section{ToxCastDB screening:}

The ToxCastDB was established to predict potential toxicity and is a costeffective approach for prioritizing thousands of chemicals that need toxicity testing (40). The data were collected by the US EPA Office of Pesticide Programs (OPP) and the National Center for Computational Toxicology (NCCT) and they were released in three different phases (57). As mentioned earlier, ToxRefDB was developed from the animal toxicity studies carried out prior to pesticide licensure, compiled as freely accessible and searchable databases $(41,57)$. ToxRefDB was critical in the development of ToxCastDB because it contains chemicals of known toxicity profiles from the ToxRefDB database (57). ToxCastDB Phase I database contains almost 300 chemicals and phase II includes 300 additional compounds, most of which are pesticides (57). The pesticides selected to be tested in high throughput assays were compiled from previously reported multiple animal toxicity studies. The objective of this process was to generate abundant data to form the basis computational predictive models of toxicity (57). Importantly, all the ToxCastDB pesticides previously met the safety standard for registration (57). Furthermore, the ToxCastDB was used to identify compounds associated with PXR activation, utilizing the NGCG, Attagene, CellzDirect and Novascreen assays which evaluated chemicals that can activate PXR or PXR target gene, CYP3A4. NGCG, Attagene, CellzDirect and Novascreen are the sources of the data in the website. The data were accessed in 2013 at http://actor.epa.gov/actor/faces/ToxCastDB/Home.jsp. The 
query was constructed by selecting first ToxCastDB and then "Gene Associated with Assays", leading to a list of genes. For our search purposes, we selected the human PXR ATG, NCGC and NVS under the "nuclear receptor subfamily 1, group I, member 2" and also the CLZD and NVS under the "cytochrome P450, family 3 , subfamily A, polypeptide 4". The hyperlinks in all cases led to tables of chemicals that activated the receptor and the gene along with the doses used in the studies.

\section{Compound selection:}

In the NHANES database, dieldrin, trans-nonachlor, DDE and DDT were associated with ALT elevation. These pesticides were therefore selected for further studies to investigate their interaction with CAR and PXR using transient transfection assays. Another candidate, chlordane, was selected because 3 compounds from the NHANES study namely heptachlor epoxide, trans-nonachlor and oxychlordane, are either components or metabolites of chlordane (58). In addition to these, we selected 3 more pesticides that are still in the market or persistent in the environment. They were selected from the list of compounds identified by ToxCastDB, and include lindane, atrazine and alachlor.

Trans-nonachlor and dichlorodiphenyldichloroethylene (DDE) were purchased from SUPELCO (Bellefonte, PA). Lindane and DDT were purchased from CHEM Service (PA) and chlordane, atrazine and alachlor were purchased from Sigma Aldrich laborchemikal (Tiedel-De Haïn, Seeize). Dieldrin was purchased from Sigma Aldrich (St. Louis, MO). 


\section{Plasmid construction:}

The reporter plasmids for human (h) PXR, were constructed by using two copies of a direct repeat 4 (DR4), an inverted repeat 1 (IR1) and a direct repeat 1(DR1) response element (RE) respectively. The top strand oligonucleotide was

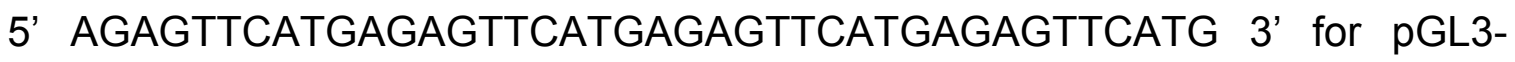
DR4-Luc, 5' AGAGGTCATTGACCTTTAGAGGTCATTGACCTTT 3' for pGL3IR1-Luc and 5' AACTAGGTCAAAGGTCAAACTAGGTCAAAGGTCAAA 3' for pGL3-DR1-Luc. The bottom complementary strands had Kpn1 and Xho1 overhangs at the 5' and 3' positions respectively. The oligonucleotides were annealed and inserted into Xho1 and Kpn1 restriction sites in the polycloning region of a modified version of pGL3 promoter vector (Promega, Madison, WI). Reporter plasmid for AhR (pXRE-SV40-Luc) was synthesized using the oligonucleotide $\quad 5^{\prime} \quad$ TCAGGCATGTTGCGTGCATCCCTGAGGCCAGCC $\quad 3$ ' inserted into the EcoR1 site of a modified version of pGL3 promoter vector. Expression vector pSG5-hPXR was a generous gift from John $\mathrm{Y}$. Chiang (Department of Integrative Medical Sciences, Northeast Ohio Medical University). Expression vector pCMV6-hCAR (CAR2) was purchased from Origene (Rockville, MD). mPXR was a generous gift from Dr. Steven Kliewer (The University of Texas Southwestern Medical Center) and mCAR was a generous gift from Tom Rushmore (Merck Research Laboratories, West Point, PA). Restriction endonucleases and T4 DNA ligase were purchased from New England BioLabs (Ipswich, MA). Dimethyl sulfoxide (DMSO) was purchased from Fisher BioReagents (Thermo Fisher Scientific, Pittsburg, PA) and rifampicin 
(RIF), androstenol and $\quad 6-(4-C h l o r o p h e n y l) i m i d a z o[2,1-b][1,3]$ thiazole-5carbaldehyde-O-(3,4-dichlorobenzyl)oxime (CITCO) were purchased from Sigma Aldrich (St. Louis, MO). Lipofectamine and Opti-MEM were acquired from Life Technologies Inc (Carlsbad, CA). Oligonucleotides were purchased from Integrated DNA Technologies (Coralville, IA).

\section{Cell culture:}

HepG2 Cells: The human hepatoma-derived cell line (HepG2) was obtained from American Type Culture Collection (ATCC, Manassas, MD). Cells were grown in Dulbecco's modified Eagle's medium (DMEM, HyClone Laboratories Inc, Thermofisher, Waltham, MA) supplemented with $10 \%$ fetal bovine serum (FBS) and $1 \%$ antimycotic/antibiotic solution (Mediatech, Manassas, VA). The cells were incubated in a $5 \%$ carbon dioxide atmosphere and $95 \%$ humidity at $37^{\circ} \mathrm{C}$ and sub-cultured every 2 days.

\section{Transfection:}

Cells were plated in Thermo Scientific Nunc 24-well plates and transfected at $40-60 \%$ confluence. The transfection mix per well contained $150 \mathrm{ng} \beta$ galactosidase expression plasmid ( $\mathrm{pCMV}-\beta$, Stratagene, $\mathrm{CA}$ ) as a transfection control, $50 \mathrm{ng}$ receptor expression plasmid and $150 \mathrm{ng}$ reporter plasmid if not otherwise specified. All cells were co-transfected by lipofection using Lipofectamine reagent according to the manufacturer's instructions and OptiMEM (reduced serum medium) as the transfecting medium. After 4 hour of incubation, the medium was changed to DMEM supplemented with $10 \%$ FBS and $1 \%$ antimycotic/antibiotic solution then cells were left overnight to recover. 
Compounds of interest were then added to the cells and cells were incubated for 24 hours. DMSO was used as a vehicle for all compounds (final concentration $<0.5 \%)$ mCAR is constitutively active and therefore its activation was measured by the ability of the compound to reverse the inhibition caused by androstenol.

\section{Reporter assay:}

Cells were washed twice with phosphate buffered saline (1X), harvested using $50 \mu \mathrm{L}$ cell lysis buffer (Promega, Madison, $\mathrm{WI}$ ) and subjected to a single freeze-thaw event. For $\beta$-galactosidase assays, cell extracts $(5 \mu \mathrm{L})$, were incubated with chlorophenol red $\beta$-galactopyranoside (CPRG, Roche Diagnostics, Indianapolis, IN) at $37^{\circ} \mathrm{C}$ for $30-60$ minutes. The enzyme activity was measured spectrophotometrically at $595 \mathrm{~nm}$ using the Bio-Tek Synergy HT multi-mode micro plate reader. Luciferase activity assays were performed on cell extracts $(5 \mu \mathrm{L})$ using the Luciferase Assay System (Promega, Madison, WI). Luminescence was measured using the Orion $\mathrm{L}$ micro plate luminometer (Berthold Detection Systems, Pforzheim, Germany) over a 10 second period. Receptor activation was measured by luciferase activity and results were normalized to the amount of $\beta$-galactosidase expressed.

\section{Statistical analysis:}

All statistical analyses were performed using GraphPad Prism version 5.01 for Windows (GraphPad Software Inc., La Jolla, CA, USA). Data are expressed as mean \pm SEM. Multiple group data were compared using One Way ANOVA followed by Bonferroni's post-hoc test for parametric data for all pairwise comparisons (59). $\mathrm{P}<0.05$ was considered statistically significant. 


\section{RESULTS}

Identification of pesticides that activate hPXR and induce its target gene CYP3A4 (EPA-ToxCast):

Two hundred eighteen different compounds were found to activate hPXR and hPXR target gene CYP3A4 at different doses (Appx. 14). For hPXR activation, 67 compounds including alachlor, were identified by the NGCG assay (Appx. 9), 102 compounds including lindane by the Attagene assay (Appx. 10) and 91 compounds by Novascreen assay (Appx. 11). For CYP3A4 induction, 202 compounds, including alachlor and atrazine were identified by the CellzDirect assay (Appx. 12) and 17 compounds by the Novascreen assay (Appx. 13). 
Identified chemicals that were mutual among the NHANES, ToxCast, ToxRef and CEBS.

After data-screening of NHANES, ToxCast, ToxRef and CEBS, we clustered the results and 30 different compounds were found to be associated with fatty liver disease in all the four databases (Table 1).

Table 1: Mutual chemicals between NHANES, ToxCastDB, ToxRefDB and CEBS databases:

\begin{tabular}{clcl}
\hline$\#$ & Chemical Name & $\#$ & Chemical Name \\
\hline 1. & Bensulide & 2. & Metalaxyl \\
\hline 3. & Buprofezin & 4. & Oxadiazon \\
\hline 5. & Butafenacil & 6. & Paclobutrazol \\
\hline 7. & Chlorpyrifos-methyl & 8. & Propiconazole \\
\hline 9. & Chlorsulfuron & 10. & Rimsulfuron \\
\hline 11. & Cyproconazole & 12. & Sethoxydim \\
\hline 13. & Dimethomorph & 14. & Sulfentrazone \\
\hline 15. & Ethofumesate & 16. & Tetramethrin \\
\hline 17. & Fenarimol & 18. & Thiacloprid \\
\hline 19. & Fipronil & 20. & Thiazopyr \\
\hline 21. & Fluazinam & 22. & Triadimefon \\
\hline 23. & Flusilazole & 24. & Triadimenol \\
\hline 25. & Fluthiacet-methyl & 26. & Trifloxystrobin \\
\hline 27. & Hexaconazole & 28. & Triflumizole \\
\hline 29. & Iprodione & 30. & Vinclozolin \\
\hline & & & \\
\hline
\end{tabular}




\section{DDT activates hepatic xenobiotic receptors $h P X R, \mathrm{mPXR}$ and hCAR.}

Transient transfection assays of HepG2 cells co-transfected with hPXR or mPXR or hCAR were performed for the following pesticides: dieldrin, transnonachlor, lindane, alachlor, chlordane, DDT and DDE, at $10 \mu \mathrm{M}$ and other concentrations to evaluate their interaction with these xenobiotic receptors.

All compounds except atrazine activated hPXR (dieldrin DDT 2 fold; transnonachlor, chlordane, DDE and alachlor $\sim 1.5$ fold; lindane $\sim 2.5$ fold). mPXR was activated by all the compounds except atrazine and dieldrin (Trans-nonachlor and DDT $\sim 2$ fold; chlordane and alachlor $\sim 1.7$ fold and DDE and lindane $\sim 1.5$ fold) (Figs. $1 \& 2$ ).

hCAR variant 2 was activated by all the compounds except atrazine, chlordane and DDE (Alachlor $\sim 1.5$ fold; DDT $\sim 1.4$ fold and Dieldrin, trans-nonachlor and lindane $\sim 1.3$ fold) (Fig. 3). On the other hand, mCAR (human variant 1 anthology) was not activated by any of the compounds tested (Fig. 4)

Concentration response relationship was also determined to identify DDT and DDE half maximal effective concentration (EC50) for further studies. The dose response curve was plotted and the $\mathrm{EC}_{50} \mathrm{~S}$ were calculated using the GraphPad Prism version 5.01. DDT was a more potent hPXR activator than DDE with an $\mathrm{EC}_{50}$ that was $2.813 \mu \mathrm{M}$ while the $\mathrm{EC}_{50}$ of DDE was $13.00 \mu \mathrm{M}$ (Fig. 5\&6). The results from the in vitro study are summarized in Table 2. 


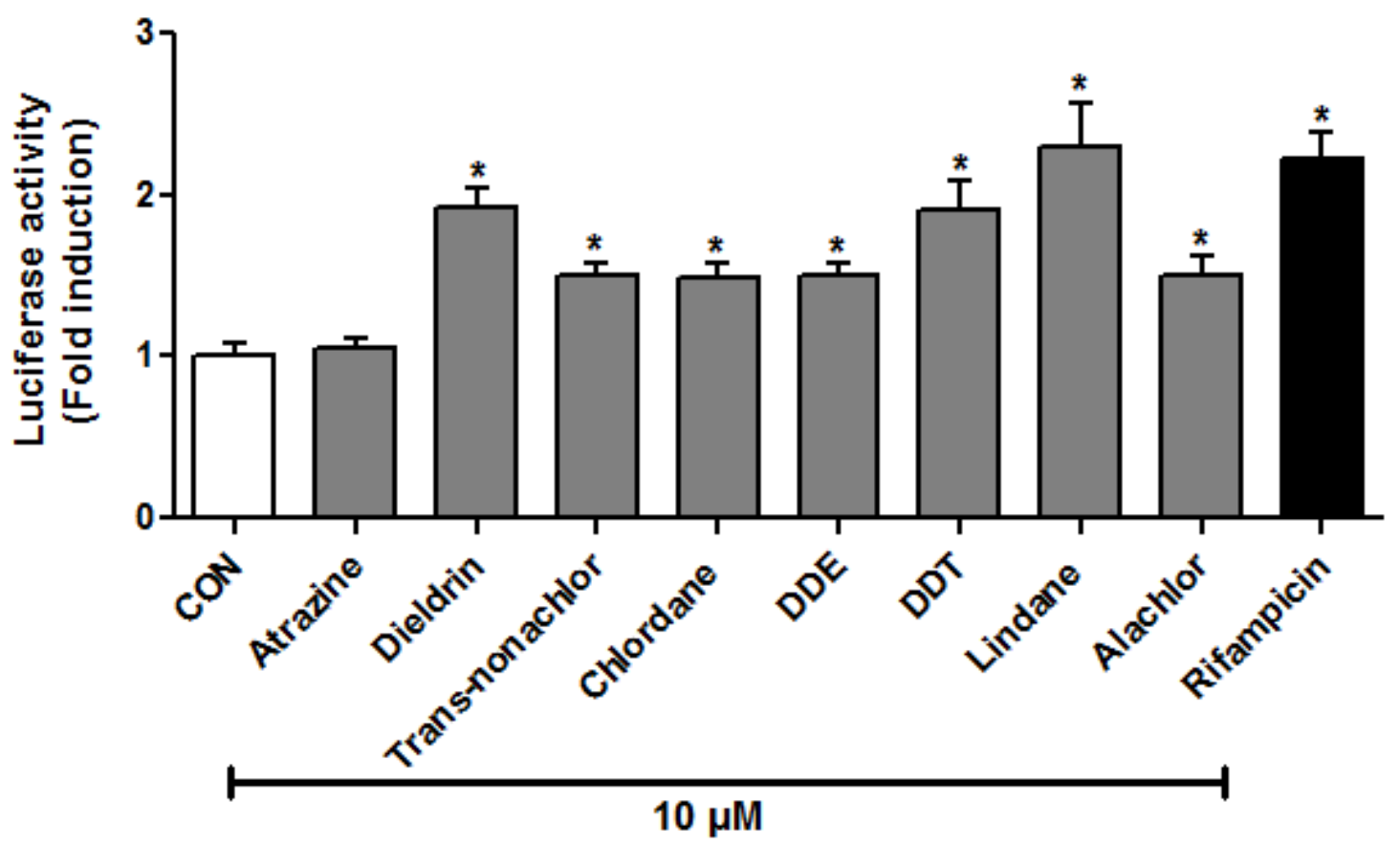

Figure 1. Activation of hPXR by pesticides:

HepG2 cells were co-transfected with $p C M V \beta, h P X R$ and $\mathrm{pGL}_{3}$-DR4-Luc and exposed to each compound at $10 \mu \mathrm{M}$. All compounds except atrazine increased the luciferase expression compared to cells exposed to DMSO (solvent control) and the highest fold induction was with dieldrin and DDT ( 2-fold). Rifampicin (10 $\mu \mathrm{M})$ was used as a positive control. ${ }^{*} \mathrm{P}<0.05$. 


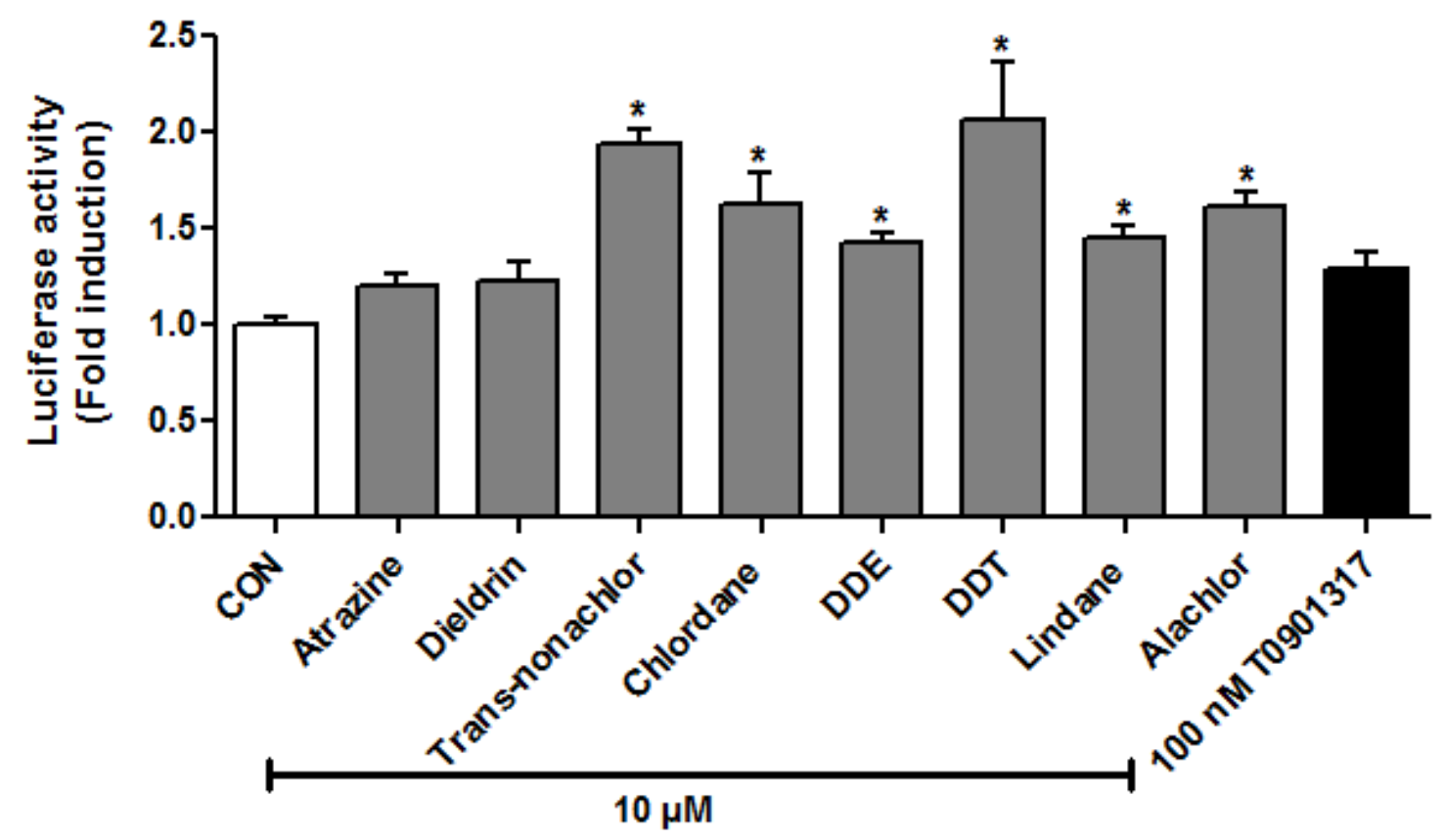

Figure 2. Activation of MPXR by pesticides:

HepG2 cells were co-transfected with $p C M V \beta, \operatorname{mPXR}$ and $\mathrm{pGL}_{3}-\mathrm{DR} 4-\mathrm{Luc}$ and exposed to each compound at $10 \mu \mathrm{M}$. All compounds except atrazine and dieldrin increased the luciferase expression compared to cells exposed to DMSO (solvent control) and the highest fold induction was with Trans-nonachlor and DDT ( 2-fold). T0901317 (100 nM) was used as positive control. * $\mathrm{P}<0.05$. 


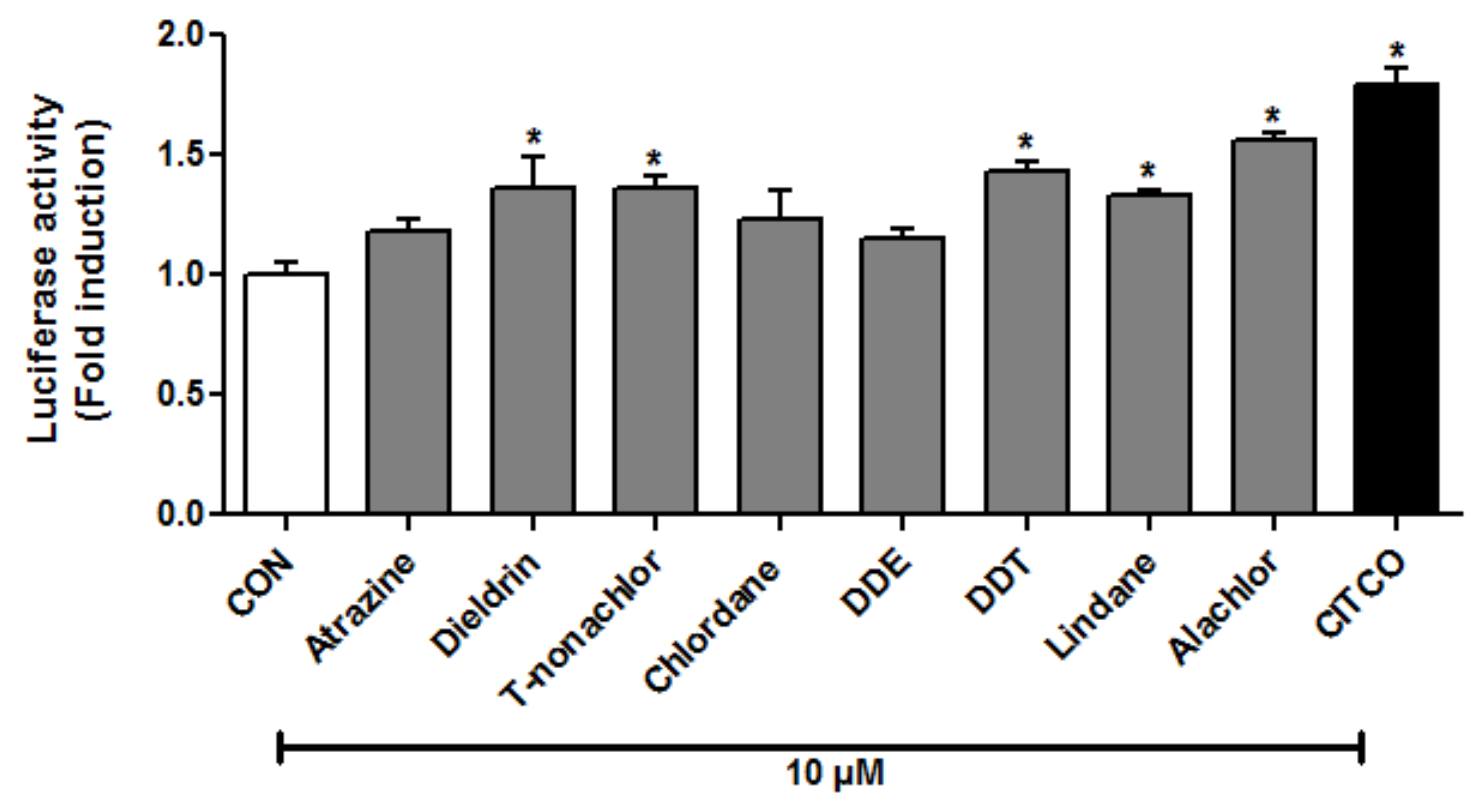

Figure 3. Activation of hCAR2 by pesticides:

HepG2 cells were co-transfected with $p C M V \beta$, hCAR2 and $\mathrm{pGL}_{3}$-DR4-Luc and exposed to each compound at $10 \mu \mathrm{M}$. All compounds except atrazine, chlordane and DDE increased the luciferase induction and the highest fold expression was with Alachlor $\sim 1.5$-fold and DDT 1.4-fold. CITCO $(10 \mu \mathrm{M})$ was used as positive control. ${ }^{*} \mathrm{P}<0.05$. 


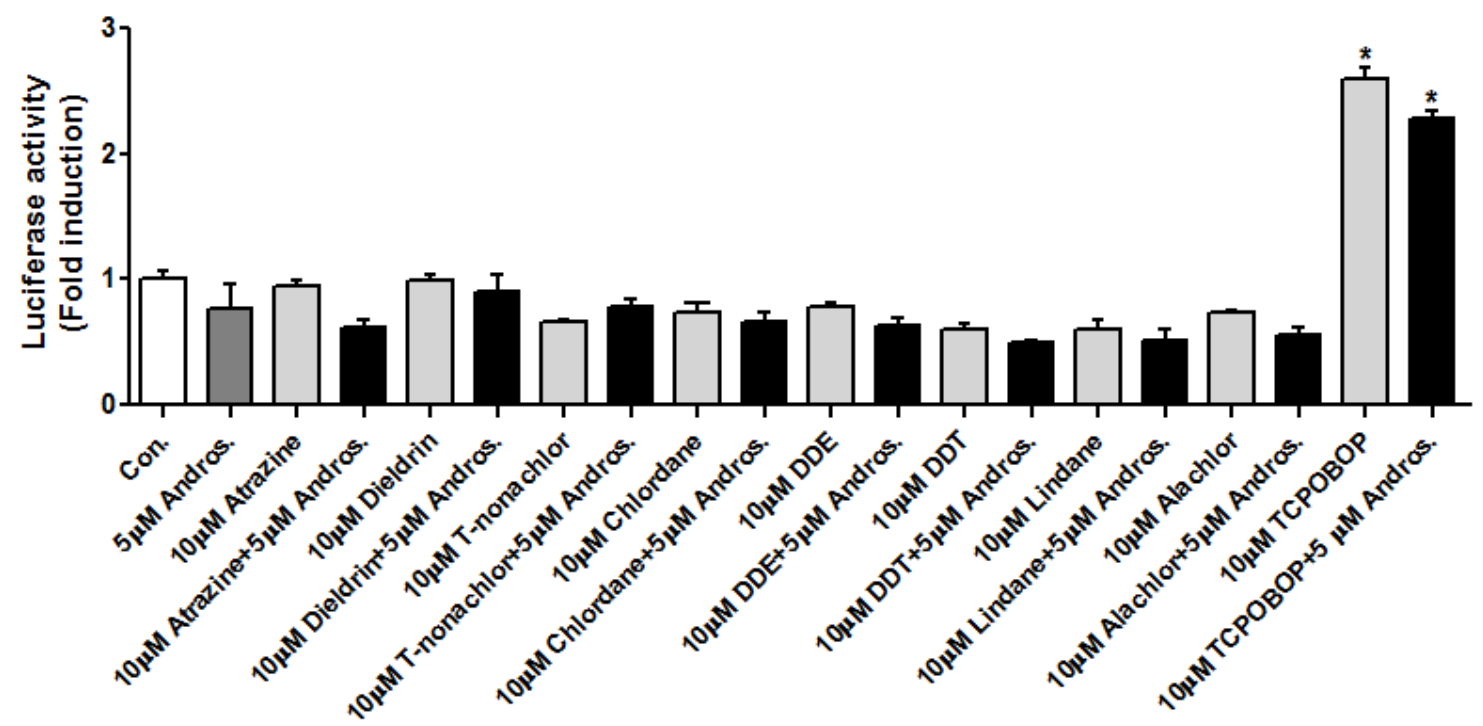

Figure 4. Activation of mCAR by pesticides:

HepG2 cells were co-transfected with $\mathrm{pCMV} \beta, \mathrm{mCAR}$ and $\mathrm{pGL}_{3}$-DR4-Luc and exposed to each compound at $10 \mu \mathrm{M}$ with and without $10 \mu \mathrm{M}$ androstenol. None of the compounds increased luciferase expression significantly. Androstenol (10 $\mu \mathrm{M})$ was used as a mCAR suppressor and as a negative control and TCPOBOP as a positive control. ${ }^{*} \mathrm{P}<0.05$. 


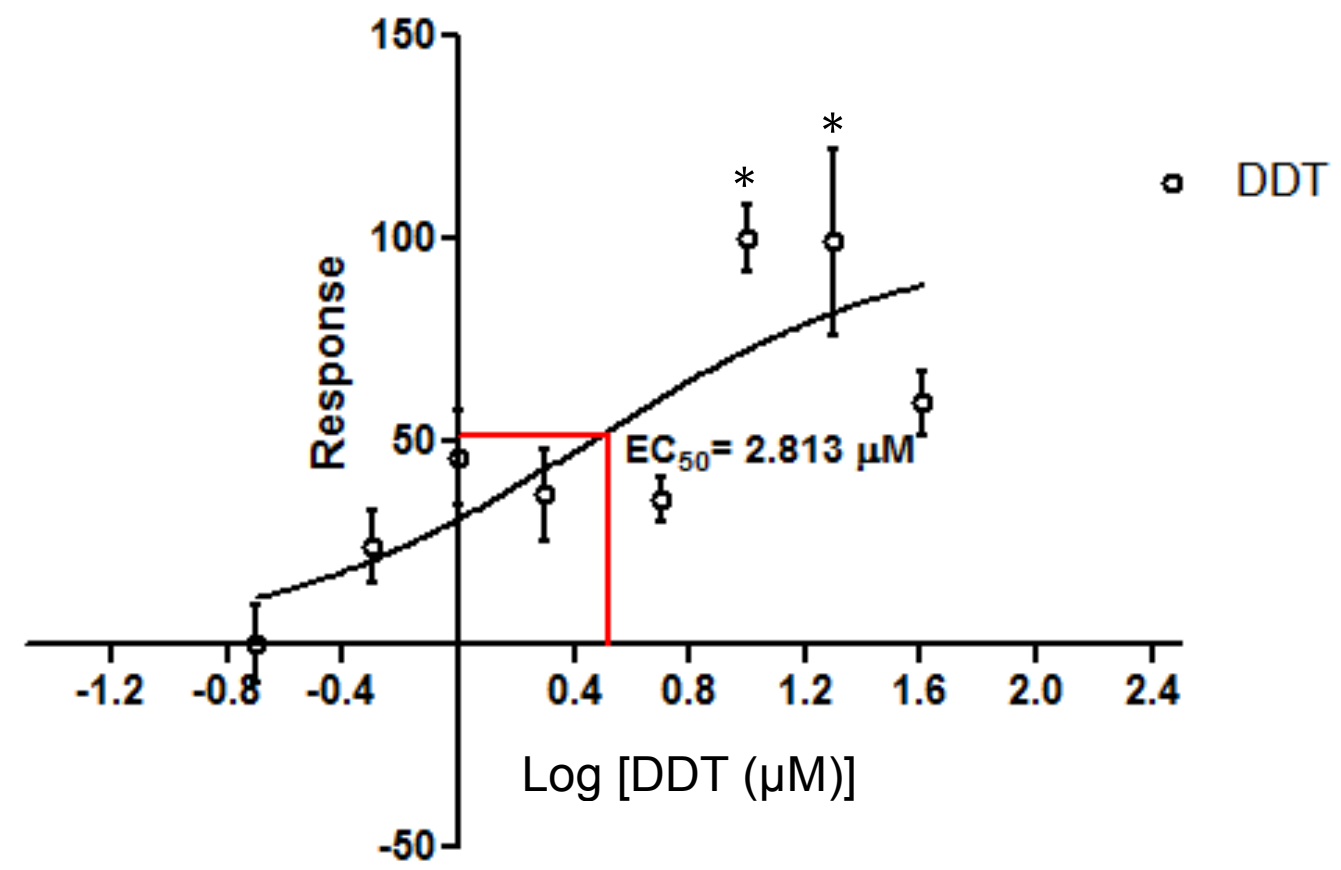

Figure 5. Concentration response curve of hPXR activation by DDT:

HepG2 cells were co-transfected with $p C M V \beta, h P X R$ and $\mathrm{pGL}_{3}$-DR4-Luc and exposed to DDT at concentrations $0.2,0.5,1,2,5,10,20$ and $40 \mu \mathrm{M}$. hPXR was activated at 10 and $20 \mu \mathrm{M}$ concentrations compared to cells exposed to DMSO. Rifampicin $(10 \mu \mathrm{M})$ was a positive control. The $\mathrm{EC}_{50}$ of DDT was calculated by GraphPad Prism $5.01\left(\mathrm{EC}_{50}=2.813 \mu \mathrm{M}\right) .{ }^{*} \mathrm{p}<0.05$. 


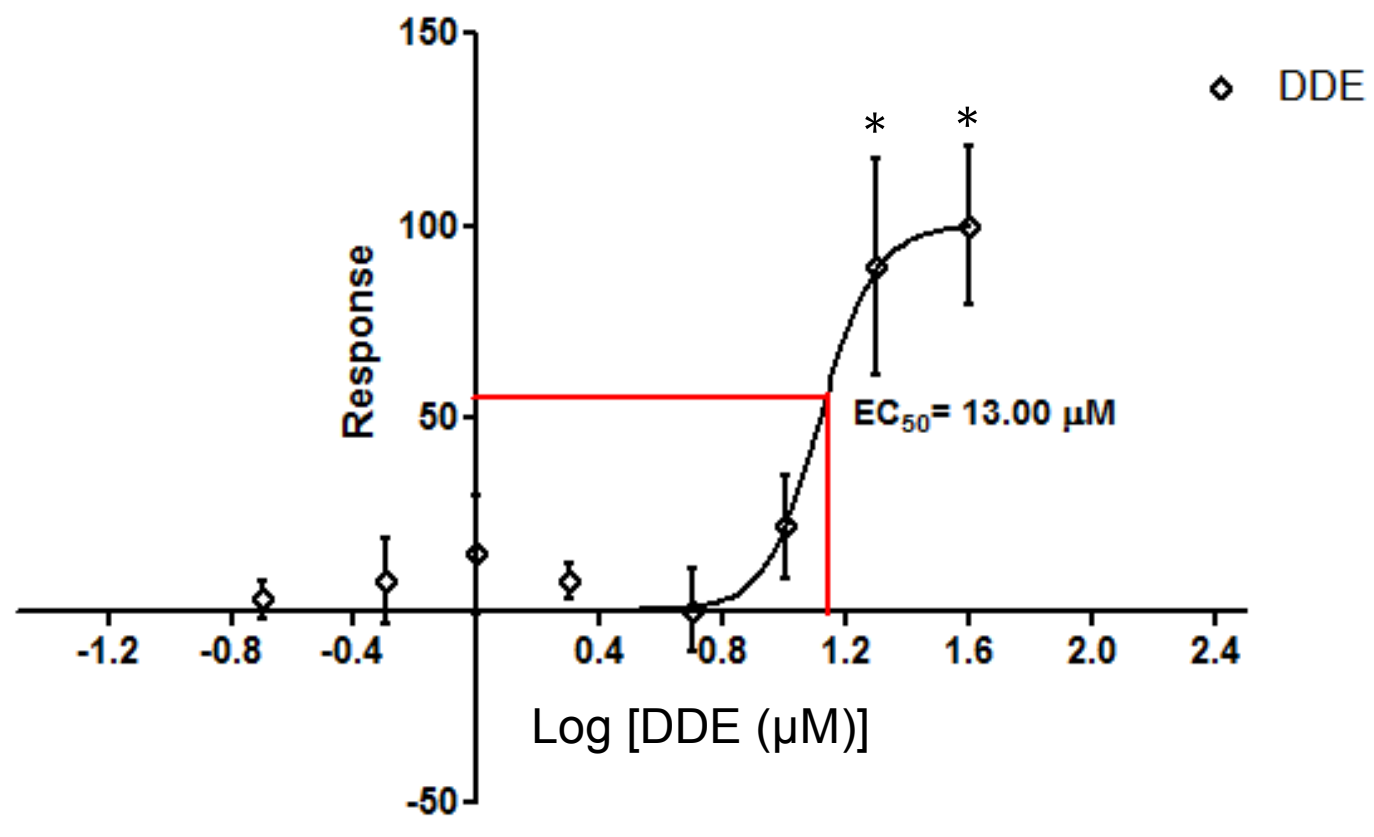

Figure 6. Concentration response curve of hPXR activation by DDE:

HepG2 cells were co-transfected with $p C M V \beta, h P X R$ and $\mathrm{pGL}_{3}$-DR4-Luc and exposed to DDE at concentrations $0.2,0.5,1,2,5,10,20$ and $40 \mu \mathrm{M}$. hPXR was activated at 20 and $40 \mu \mathrm{M}$ concentrations compared to cells exposed to DMSO. Rifampicin $(10 \mu \mathrm{M})$ was a positive control. The $\mathrm{EC}_{50}$ of DDT was calculated by GraphPad Prism $5.01\left(\mathrm{EC}_{50}=13.00 \mu \mathrm{M}\right) .{ }^{*} \mathrm{P}<0.05$. 
Table 2. Summary of results of the transient transfection assays:

\begin{tabular}{clcccc}
\hline$\#$ & Pesticide Name & hPXR & mPXR & hCAR & mCAR \\
\hline 1. & Atrazine & - & - & - & - \\
\hline 2. & Dieldrin & + & - & + & - \\
\hline 3. & Trans-nonachlor & + & + & + & - \\
\hline 4. & Chlordane & + & + & - & - \\
\hline 5. & DDE & + & + & - & - \\
\hline 6. & DDT & + & + & + & - \\
\hline 7. & Lindane & + & + & + & - \\
\hline 8. & Alachlor & + & + & + & - \\
\hline
\end{tabular}




\section{DISCUSSION}

Data screening from the three databases; ToxRefDB, CEBS and NHANES, highlighted the role of pesticides in NAFLD pathogenesis, therefore, inspiring a more detailed investigation into the suggested mechanisms correlated with liver disease. We mined the ToxCastDB database that warehouses highthroughput assays (NGCG, Attagene, CellzDirect and Novascreen), which evaluated chemicals that can activate human PXR or induce its target gene, CYP3A4. Over 200 compounds activated hPXR or induced CYP3A4. Interestingly, some of these compounds are pesticides which are still used in the U.S. or banned but persistent in the environment such as alachlor, an herbicide used in corn fields, lindane, a pesticide in shampoos for lice, and atrazine, a herbicide. Moreover, after screening the databases, 30 chemicals were mutually presented (Table 2).

In the next step of this study, we selected eight pesticides that were relevant to human exposure (NHANES) and human PXR activation (ToxCastDB). Transient transfection assays to study receptor activation demonstrated that almost all the pesticides activated human and/or mouse PXR and human CAR. The compounds selected from the ToxCastDB that were hPXR activators were further validated in our studies and their activation of hPXR was verified. Our results suggest that interaction with PXR might be a crucial molecular mechanism for NAFLD development in humans with compounds such as dieldrin, trans-nonachlor, lindane, alachlor, chlordane, DDT and DDE, but it might 
not be with atrazine at the tested dose. Among the eight compounds studied, DDT appeared to be the strongest activator of $h P X R, M P X R$ and $h C A R$. Likewise, DDE, the major metabolite of DDT, also activated $\mathrm{hPXR}$ and $\mathrm{mPXR}$. Therefore, DDT and DDE were further tested at graded concentrations to measure their half maximal effective concentration (EC50); $2.813 \mu \mathrm{M}$ for DDT and $13.00 \mu \mathrm{M}$ for DDE. 
CHAPTER 4

\section{DDT DID NOT WORSEN NAFLD IN DIET INDUCED OBESITY MODEL INTRODUCTION}

The transient transfection experiments indicated that DDT and its major metabolites DDE are highly associated with the suggested mechanisms of liver disease development, which is consistent with the NHANES report wherein DDE reportedly showed the highest Lipid-adjusted serum levels concentration; 1535 ng/g (Fig. 7). These findings made DDT a good candidate for further evaluation with respect to NAFLD in an animal model of DIO. 


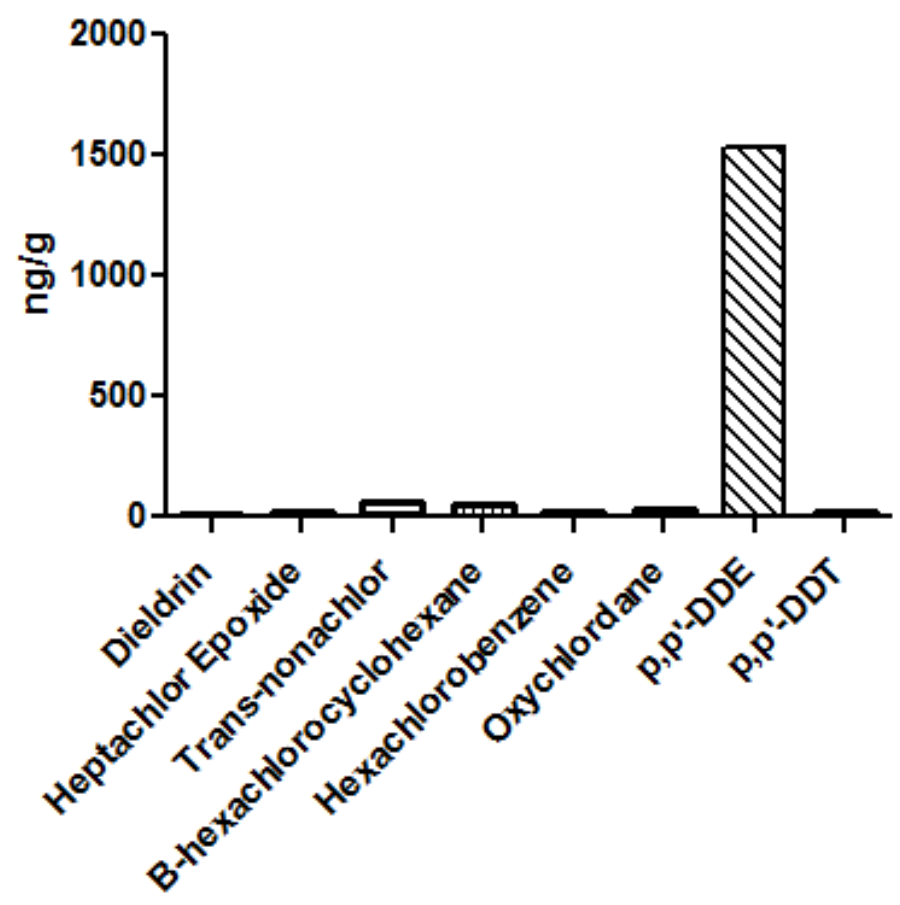

Figure 7. Lipid-adjusted serum levels of organochlorine compounds:

The median lipid adjusted serum levels of organochlorine compounds detected in the $4^{\text {th }}$ quartile of NHANES population showed that DDE had the highest median lipid-adjusted serum concentration (1535 ng/g) compared to the other 7 organochlorine compounds. 
Both human and animal studies have shown induction of CYP450s by DDT, in particular CYP2B and CYP3A (60). DDT induction of P450 is thought to be primarily through CAR activation, suggesting that DDT can also exhibit the phenobarbital-like hepatic tumor promoting activities as seen in rats and mice (60-63).

DDT is an organochlorine pesticide first discovered by the Swiss scientist Paul Hermann Muller in 1939 (64). DDT was used mainly as an insecticide to control malaria and typhus and its usage has saved millions of lives (64). DDT was banned in the U.S. and many other countries in the early 1970 s because it was reported in high concentrations in aquamarine animals and it was also found to cause sever developmental toxicity to birds $(64,65)$. However, DDT is still used in many African countries to control malaria. DDT is a highly lipophilic persistent organic pollutant (65). DDT bio-accumulates in living organisms' fat tissue and hence, it still persists in the environment, and one way of exposure in mammals is through breast milk (60). In fact, it has been stated that there is no living organism on the planet that is free from DDT $(22,66)$.

DDT toxicity is directed mainly to freshwater and marine microorganisms, fishes, amphibians and birds (66). DDT residues were found in almost all the U.S. great lakes. In fact, DDT was banned in the U.S. in 1972 after many investigations, research and reports of the bioaccumulation of DDT and its metabolites in toxic levels in birds and aquamarine organisms, such as fish, invertebrates, and plants, as a food source for humans and animals. The DDT tissue accumulation in the aquamarine organisms was reported in concentrations 
much higher than those in the physical environment. Studies have also shown that DDT use killed aquatic invertebrates in field situations. Therefore, by the 1960s and 1970s, DDT was known to be significantly prevalent in the aquatic ecosystems and in some aquatic animals and plants in the U.S. (65). In addition, in 1958, wild birds death took place after DDT applications and when the DDT residues were measured in these animals, they were similar to those measured in poultry fed DDT containing diet in a study in 1947. DDT levels bioaccumulation in birds can be dangerous when DDT and its residue DDD (dichlorodiphenyldichloroethane) levels reach $30 \mathrm{ppm}$ or more in the brain. Under stress, such as migration, birds mobilize the stored DDT in the fat increasing the risk of reaching toxic serum and brain DDT levels. Furthermore, around the period when DDT was heavily used, it was reported that the number of Osprey birds decreased noticeably in the East Coast nesting colonies. The reported decrease in the number of these birds was reasoned to the death of these animals as well as the failure of their eggs to hatch due to thin eggshells and embryonic death. The phenomenon was also repeatable in laboratory animals. Additionally, the increase in the numbers of birds after the reduction and ban of DDT application was also reported in may studies. DDT and its metabolites were also reported to be accumulated in tissues, such as the brain, liver, adipose, muscles and others in mammals including rodents, rabbits, deer, bears and others. Moreover, it was also reported that DDT decreases the oxygen evolved from the phytoplankton, which are the main source of world's oxygen (65). 
Both DDT and DDE are classified by the International Agency for Research on Cancer (IARC) as probable Group 2B carcinogens (67). In fact, in a clinical trial in Linxian, China, 168 of the trial subjects developed liver cancer, and compared to control subjects, they had higher rate of Hepatitis B surface antigen (HBsAg) positivity (68). Additionally, DDT is associated with hepatic tumorigenesis in mice at higher doses (60). DDT has also been linked to neurotoxicity in animals and neonatal exposure in humans affects neurocognition (60). DDT was also reported to cause abnormalities in sperm characteristics. Furthermore, DDE is antiandrogenic while DDT is estrogenic; however, studies found that DDT displays no teratogenic effect (60).

Technically, DDT is a mixture of 3 main compounds, DDT, DDE (dichlorodiphenyldichloroethylene) and DDD; with DDT representing the highest proportion of the mixture while both DDE and DDD are DDT metabolites. DDT and its major metabolite, DDE, have long half-lives, approximately 7 and 10 years in humans, respectively $(69,70)$. Seventy to eighty percent of DDT is absorbed in the gastrointestinal tract but this is dependent on the vehicle used. DDT metabolism in rodents occurs via two different routes, urinary and hepatic. DDA is the major urinary metabolite of DDT while DDE and DDD are the major hepatic metabolites (60). The $\mathrm{LD}_{50}$ of DDT in mice reported by ATSDR ranges between $152.3-1466 \mathrm{mg} / \mathrm{kg} /$ day. Different $L_{50} \mathrm{~S}$ of DDT in mice were reported in different studies and the wide range is reasoned to the use of mice of different strains, ages and genders in these studied (71). 
The purpose of this study is to determine if DDT exposure results in NAFLD either by itself or in conjunction with high fat diet (HFD). 


\section{MATERIALS AND METHODS}

\section{Animals and diets:}

The protocol of the animal study was approved by the University of Louisville Institutional Animal Care and Use Committee (IACUC). In this 12-week study, 11 week old male C57BI/6J mice from the Jackson Laboratory (Bar Harbor, ME, USA) were divided into 4 study groups $(n=10)$ based on diet and DDT exposure. Mice were fed either a control diet (CD): 10.2\% kCal from fat (TD.06416 Harlan Teklad) or a high fat diet (HFD): $42 \% \mathrm{kCal}$ from fat (TD.88137 Harlan Teklad). DDT (CHEM Service, PA) was administered on Weeks 3, 5, 7 and 9 by i.p. (intraperitoneal) injections in corn oil (vs. corn oil alone) at four individual doses of $25 \mathrm{mg} / \mathrm{kg}$ (100 mg/kg cumulative). Mice were housed in a temperature and light controlled-room (12 hour light/dark) with food and water. Animal weight and food consumption were measured every week in this 12-week study. The animals were euthanized with sodium pentobarbital $(40 \mathrm{mg} / \mathrm{kg}$ body weight, i.p. injections) at the end of Week 12. Prior to euthanasia, the animals were fasted for $6 \mathrm{~h}(5: 00 \mathrm{AM}-11: 00 \mathrm{AM})$ and \% fat composition and lean tissue weight were measured by a dual energy X-ray absorptiometry (DEXA) scanner (Lunar PIXImus densitometer, WI, USA).

\section{Glucose tolerance test (GTT):}

One week before euthanizing the animals, GTT was performed. On the day of the test, mice were fasted for $6 \mathrm{~h}$ (5:00 AM - 11:00 AM). A hand-held glucometer (ACCU-CHECK Aviva, Roche, Basel, Switzerland) was used to measure the fasting blood glucose levels using 1-2 $\mu \mathrm{L}$ blood via tail snip $(59,72)$. Animals 
were then injected with $1 \mathrm{mg}$ glucose/g body weight in sterile saline as i.p. injections and blood glucose levels were measured at 5, 15, 30, 60, 90 and 120 min after the injection.

\section{Liver and white adipose tissue histological studies:}

Liver sections were fixed in $10 \%$ buffered formalin for $48 \mathrm{~h}$ and then embedded in paraffin for histological examinations. The tissues then were sectioned and after drying they were then stained with hematoxylin-eosin (H\&E). After drying, the stained tissues were examined under light microscopy at $10 \mathrm{X}$ and $40 \mathrm{X}$ magnification. Photomicrographs were captured using a Nikon Eclipse E600 Microscope (59).

\section{Cytokine and adipokine measurement:}

Plasma cytokine and adipokine levels were measured with the Milliplex Plasma Cytokine and Adipokine Kits (Millipore Corp, Billerica, MA, USA) on the Luminex IS 100 system (Luminex Corp, Austin, TX, USA), as per manufacturer's instructions. The Piccolo Xpress Chemistry Analyzer using the Lipid Panel Plus reagent discs (Abaxis, Union City, CA, USA) was used to measure plasma aspartate transaminase (AST), alanine transaminase (ALT), low density lipoproteins (LDL), high density lipoproteins (HDL), triglycerides (TG) and total cholesterol levels (59).

\section{Real-time PCR:}

Total RNA was extracted from animal liver tissue samples by homogenizing the tissues using the RNA-STAT 60 protocol (Tel-Test, Austin, TX, USA) (59). The QuantiTect Reverse Transcription Kit (Qiagen, Valencia, CA, USA) was used to 
synthesize cDNA from the total RNA (59). Hepatic gene expression was measured with StepOnePlus (Applied Biosystems) using Taqman Universal PCR Master Mix (Life Technologies, Carlsbad, CA, USA) (59). Primer sequences from Taqman Gene Expression Assays (Applied Biosystems, Foster City, CA) were as follows: tumor necrosis factor alpha (TNFa) (Mm00443258-m1), fatty acid synthase (FAS) (Mm00662319-m1), carnitine palmitoyl transferase 1A (CPT1A) (Mm01231183-m1), cytochrome P450s [Cyp4a10 (Mm02601690-gH), Cyp2b10 (Mm01972453-s1), Cyp3a11 (Mm007731567-m1), CD36 (Mm01135198-m1), interleukin 6 (IL-6) (Mm00446190-m1), monocyte chemo attractant protein-2 (MCP-2) (Mm01297183-m1) and tissue plasminogen activator inhibitor (tPAl-1) (Mm00435860-m1) (59). mRNA levels were normalized relative to the amount of GAPDH mRNA, and expression levels in mice fed control diet and administered vehicle were set at $100 \%$ (59). Gene expression levels were calculated according to the $2^{-\Delta \Delta C t}$ method $(59,73)$.

\section{Statistical Analysis:}

Statistical analyses were performed using GraphPad Prism version 5.01 for Windows (GraphPad Software Inc., La Jolla, CA, USA). Data are expressed as mean \pm SEM. Multiple group data were compared using two Way ANOVA followed by Tukey test for all pairwise comparisons (59). P $<0.05$ was considered statistically significant. 


\section{RESULTS}

\section{DDT did not induce obesity in mice fed either CD or HFD.}

Bodyweights (BW) were measured and the increase in BW with time was calculated. The BW gain with time for CD-fed mice was considered 100\%. CDfed mice did not show an increase in BW with time and this was not affected by

DDT co-exposure. HFD feeding resulted in an increase in BW with time $(163.94 \pm 4.69 \%, p<0.001)$ but this was not affected by DDT co-exposure (145.29 $\pm 5.61 \%$ ) (Fig. 8). Likewise, HFD feeding resulted in an increase in food consumption $(\mathrm{kCal} /$ mouse $)(43.95 \pm 0.99, \mathrm{p}<0.001)$ and this was not affected by DDT co-exposure (47.61士0.99) (Fig. 9).

Fat tissue and lean tissue weight $(\mathrm{g})$ were measured by scanning the animals using the DEXA scanning analyses. DDT exposure in CD-fed mice decreased the fat tissue weight $(6.31 \pm 1.085, p=0.027)$ vs. CD only. HFD feeding increased the fat tissue weight in mice $(15.68 \pm 1.085, p<0.001)$ but DDT co-exposure had no effect (11.56 \pm 12.297$)$ (Fig. 10). Neither HFD feeding nor DDT exposure affected lean tissue weight in any group (Fig. 11). Epididymal weight/body ratio weight (EW/BW) was calculated and HFD feeding increased the EW/BW $(0.068 \pm 0.005, p<0.001)$ but DDT had no effect on it $(0.056 \pm 0.006)$ (Fig. 12). The liver weight to body weight ratio (LW/BW) ratio was also calculated and HFD feeding increased the LW/BW $(0.048 \pm 0.002, p=0.022)$. However, DDT coexposure resulted in a decrease in the LW/BW caused by HFD $(0.040 \pm 0.003$, $p=0.038)$. There was a significant interaction between HFD and DDT (Fig. 13). 


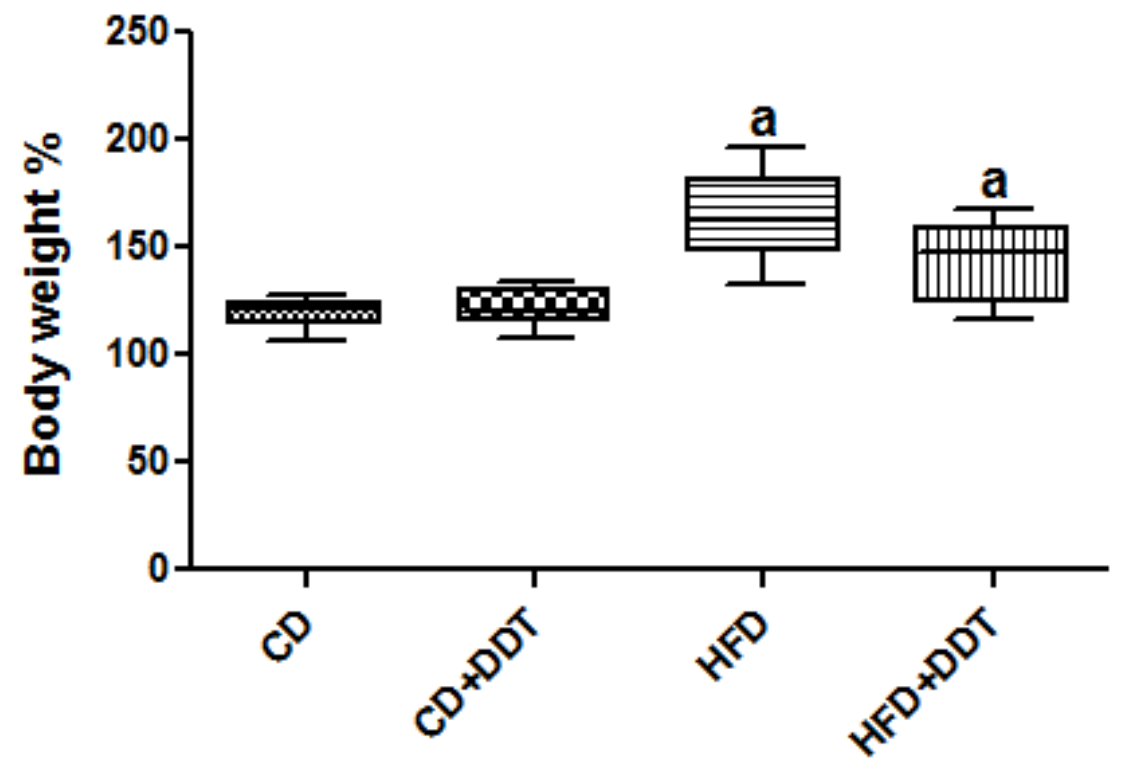

Figure 8. DDT did not affect body weight gain in either CD- or HFD- fed mice:

CD-fed mice did not show an increase in BW with time and this was not affected by DDT co-exposure. HFD feeding resulted in an increase in BW with time ( $p$ $<0.001)$ and DDT co-exposure did not affect that. The mice weights in the 12th week of the study were compared to the initial body weights to calculate the percentage of the body weight gain. Data are expressed as mean \pm SEM and analysis was performed using Two Way ANOVA. ( $P<0.05$, a: due to HFD effect). 


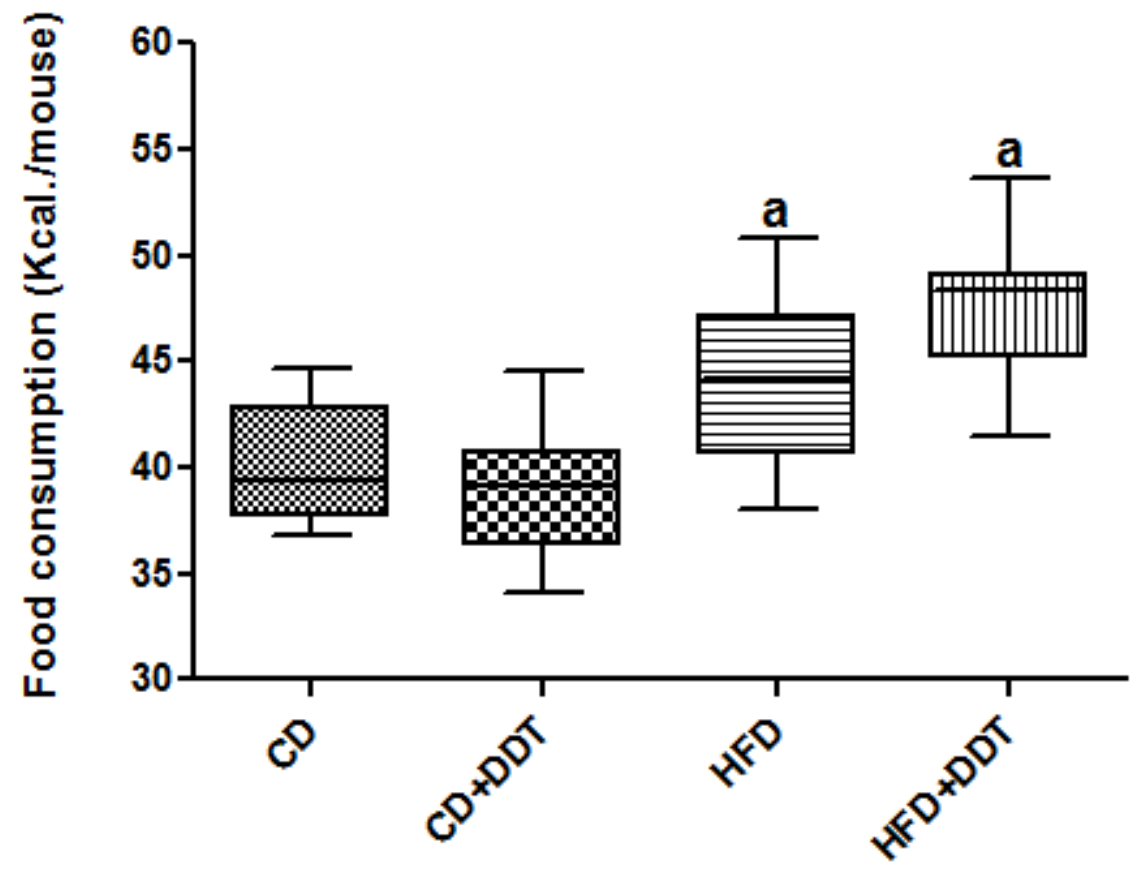

Figure 9. DDT did not affect food consumption in either CD- or HFD- fed mice:

The food consumption ( $\mathrm{kCal} /$ mouse/week) increased significantly with HFD feeding $(p<0.001)$ and it was not affected by DDT co-exposure. The food consumption of animals was measured every week during the 12 week study then the average of food consumption was calculated and converted into $\mathrm{kCal}$ for each mouse. Data are expressed as mean \pm SEM and analysis was performed using Two Way ANOVA. ( $P<0.05$, a: due to HFD effect). 


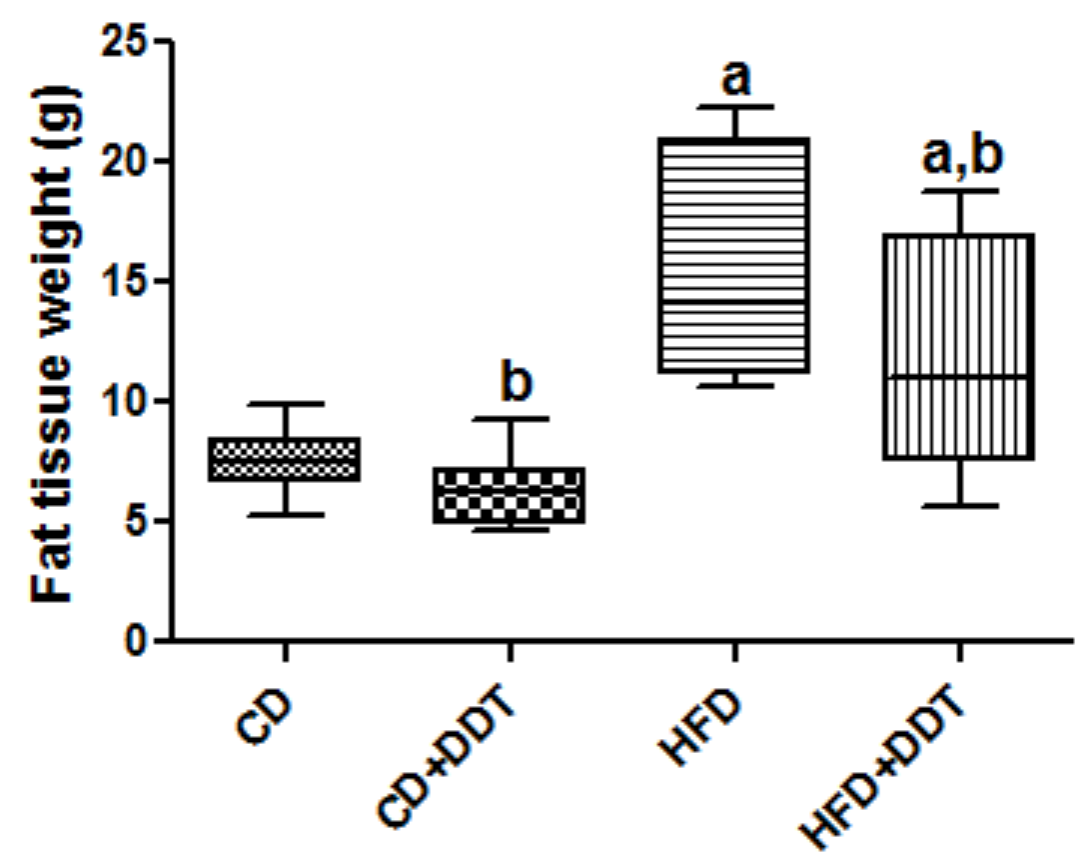

Figure 10. DDT decreased fat tissue weight in both CD- and HFD-fed mice:

After 12 weeks, DDT exposure in CD-fed mice decreased the fat tissue weight $(p=0.027)$ vs. $C D$ only. HFD feeding increased the fat tissue weight in mice $(p<0.001)$ but DDT co-exposure had no effect. The Dual energy $\mathrm{X}$-ray absorptiometry (DEXA) scanning analyses was used for measurements and the data are expressed as mean \pm SEM. Analysis was performed using Two Way ANOVA. ( $P<0.05$, a: due to HFD effect, and $b$ : due to DDT effect). 


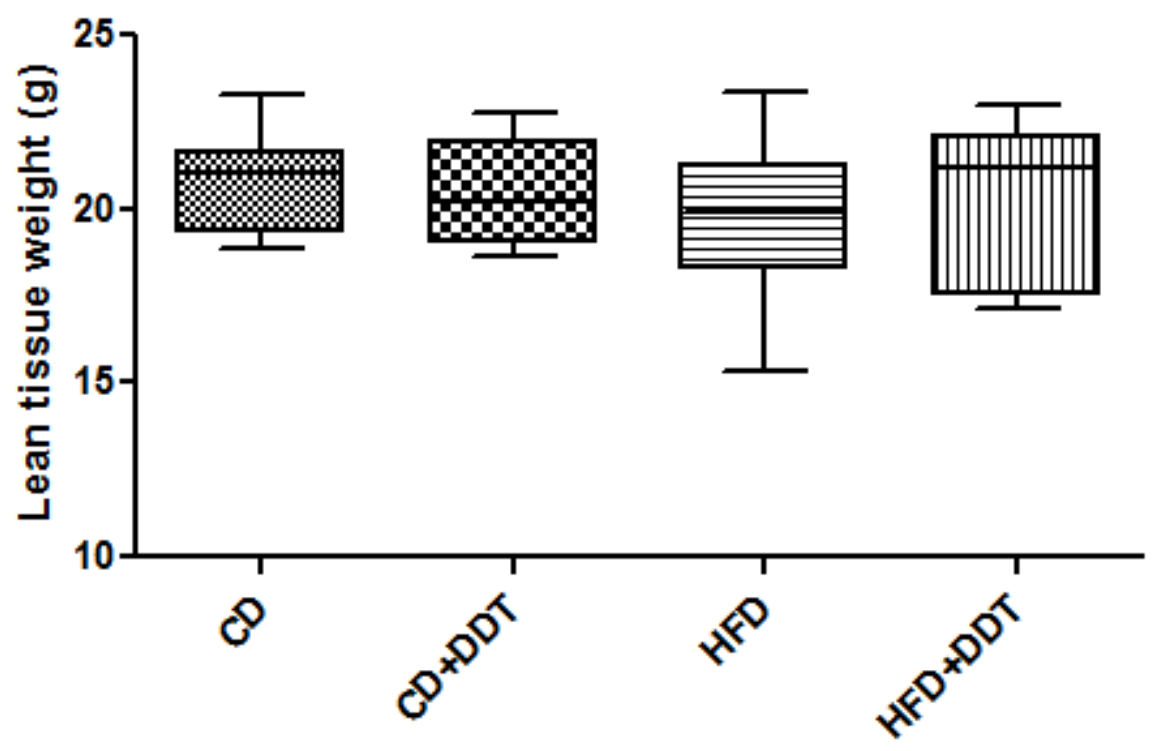

Figure 11. Neither DDT nor HFD affected the lean tissue weight:

After 12 weeks, neither HFD feeding nor DDT exposure affected lean tissue weight in CD or HFD mice. The Dual energy X-ray absorptiometry (DEXA) scanning analyses was used for measurements and the data are expressed as mean \pm SEM. Analysis was performed using Two Way ANOVA and the data showed no significance. 


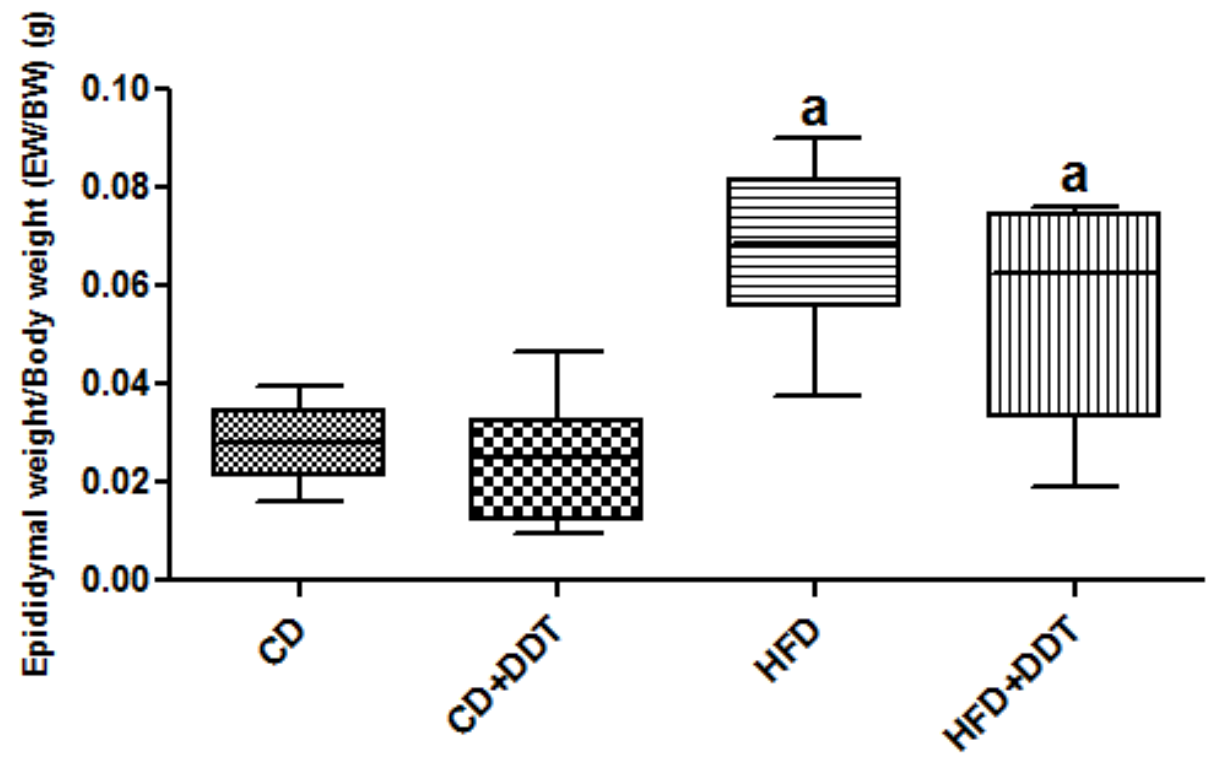

Figure 12. DDT did not affect the epididymal weight per body weight ratio in CD- and HFD-fed mice:

HFD feeding increased the EW/BW $(p<0.001)$ but DDT had no effect on it. Weights of white adipose tissue were measured after euthanization and the data are expressed as mean \pm SEM. Analysis was performed using Two Way ANOVA. $(P<0.05$, a: due to HFD). 


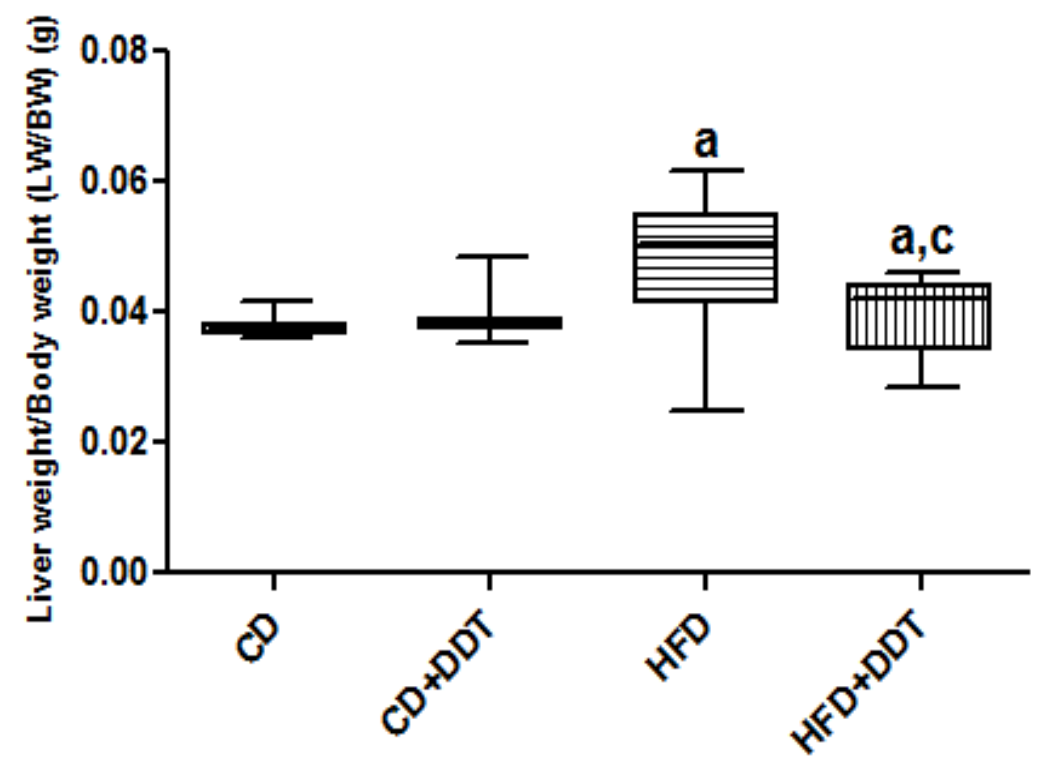

Figure 13. DDT decreased the liver weight per body weight ratio in HFD-fed mice:

HFD feeding increased the LW/BW $(p=0.022)$. DDT co-exposure resulted in a decrease in the LW/BW caused by HFD $(p=0.038)$. Weights of livers were measured after euthanization and data are expressed as mean $\pm S E M$. Analysis was performed using Two Way ANOVA. $(\mathrm{P}<0.05$, a: due to HFD, and c: interaction between HFD and DDT). 


\section{Effect of DDT exposure on liver injury.}

Plasma ALT and AST levels were measured using the Piccolo Xpress Chemistry Analyzer. The data demonstrated that DDT exposure resulted in decreased plasma ALT levels in both the CD- and HFD- fed mice (CD+DDT: 48.80 \pm 25.59 $\mathrm{U} / \mathrm{L}$ and HFD+DDT: $52.57 \pm 30.59 \mathrm{U} / \mathrm{L}, \mathrm{p}=0.048$ ) (Fig. 14). On the other hand, neither DDT nor HFD affected plasma AST levels (Fig. 15).

Steatosis and liver injury were also assessed by H\&E staining of liver sections. CD-fed group with or without DDT exposure showed no evidence of steatosis. However, HFD-fed groups with or without DDT exposure developed steatosis with some liver sections. Interestingly, some of HFD-fed mice co-exposed to DDT showed less or no steatosis. Additionally, there was no sign of inflammation in any of the groups. (Fig. 16). 


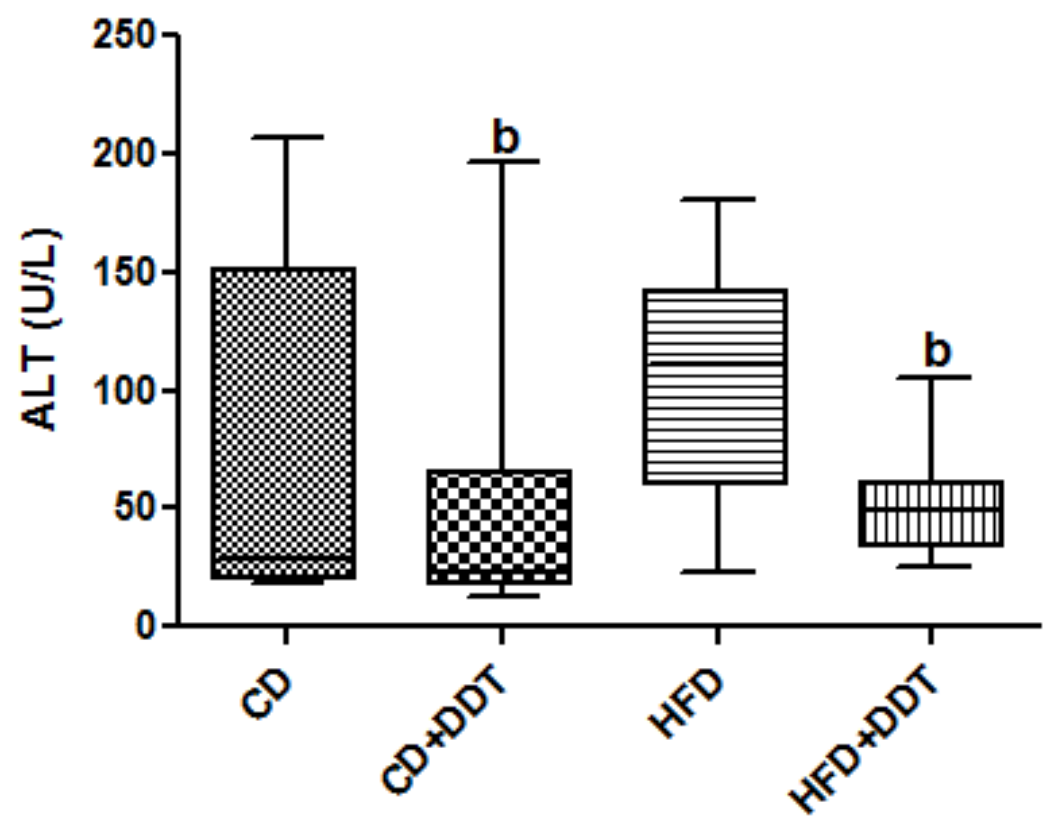

Figure 14. DDT decreased ALT levels in CD and HFD animals:

DDT exposure resulted in decreased plasma ALT levels in both the CD- and HFD- fed mice $(p=0.048)$. The Piccolo Xpress Chemistry Analyzer was used to measure plasma levels of ALT and data are expressed as mean \pm SEM. Analysis was performed using Two Way ANOVA. ( $P<0.05$, b: due to DDT effect). 


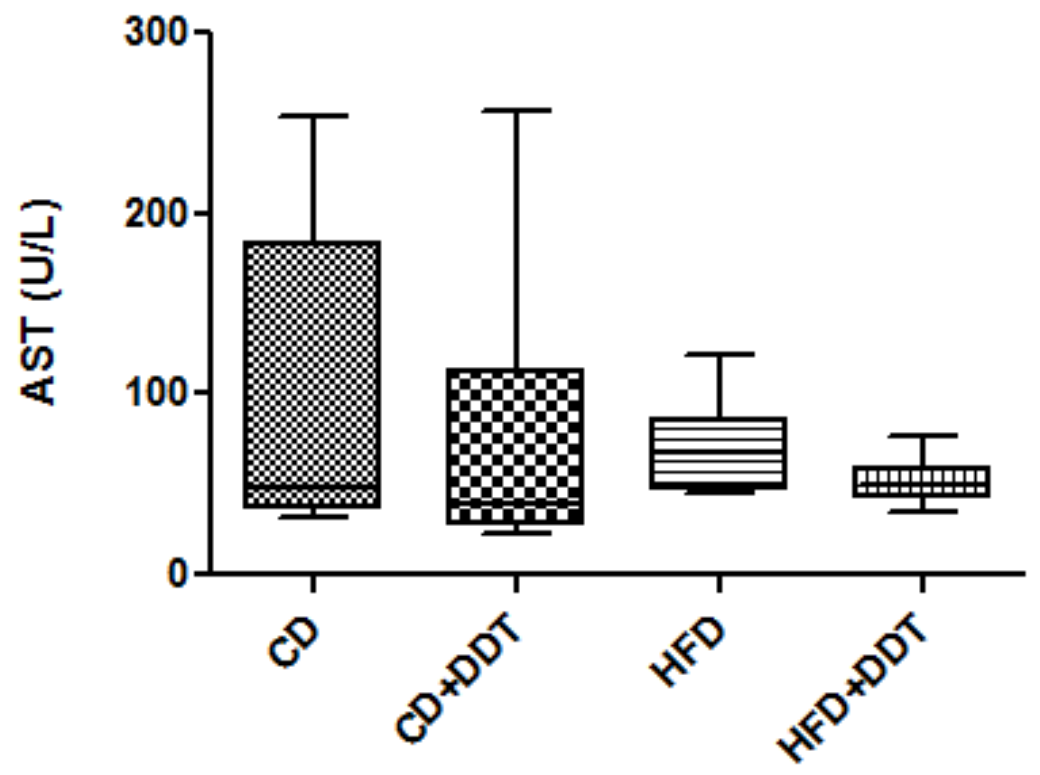

Figure 15. Neither DDT nor HFD affected AST plasma levels:

Neither DDT nor HFD affected plasma AST levels. The Piccolo Xpress Chemistry Analyzer was used to measure plasma levels of ALT and data are expressed as mean \pm SEM. Analysis was performed using Two Way ANOVA and the data showed no significance. 


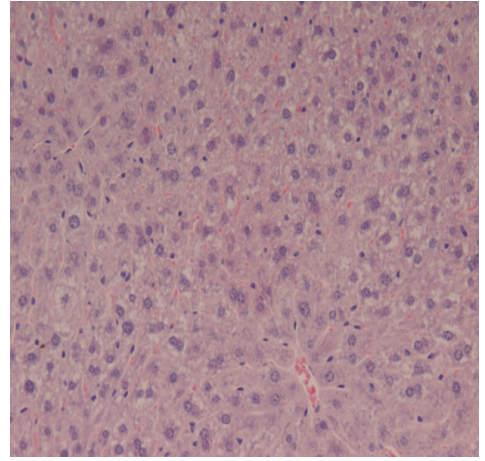

CD

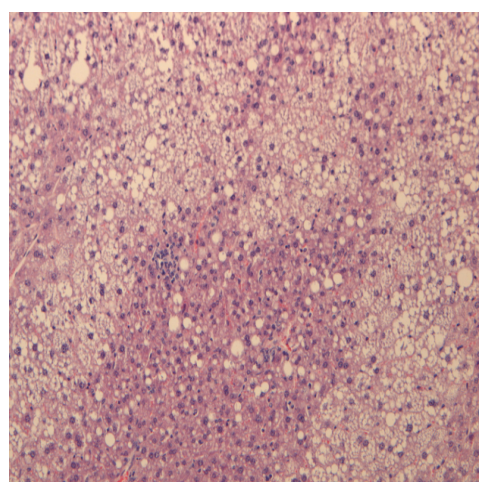

L

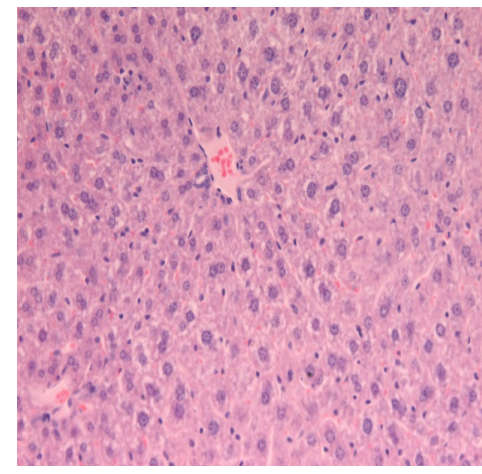

CD+D
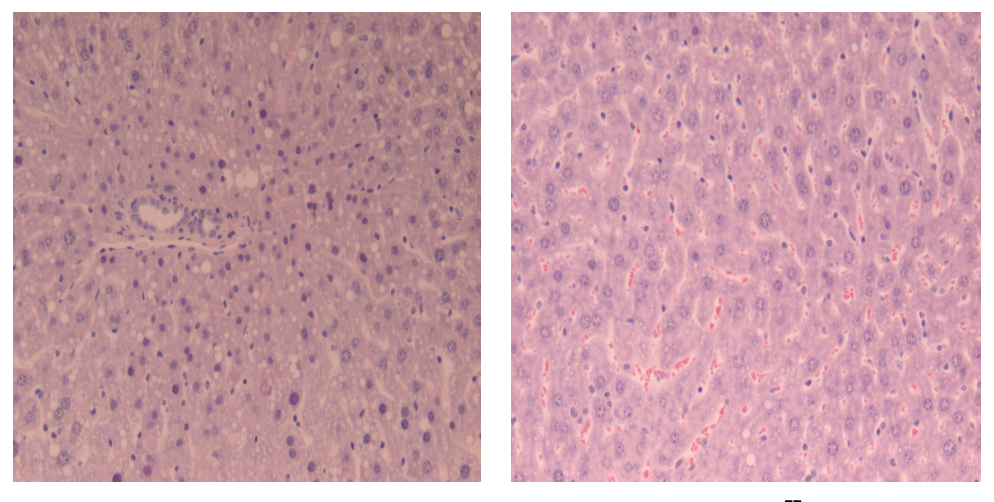

\section{HFD+DDT}

Figure 16. H\&E staining of liver tissues:

The H\&E staining of the liver tissues of CD-fed group with or without DDT exposure showed no evidence of steatosis. HFD-fed groups with or without DDT exposure developed steatosis, but some of HFD-fed mice co-exposed to DDT showed less or no steatosis. There was no sign of inflammation in any of the groups. 


\section{Effects of DDT on glucose tolerance test (GTT).}

Glucose tolerance test (GTT) was performed one week prior to euthanizing the animals. HFD feeding increased blood glucose levels $(\mathrm{mg} / \mathrm{dL})$ but this was not affected by DDT co-exposure (Fig. 17). Likewise, HFD feeding increased fasting blood glucose levels $(211.70 \pm 9.109 \mathrm{mg} / \mathrm{dL}, \mathrm{p}=0.009)$ but this was not affected by DDT co-exposure $(207.57 \pm 10.887 \mathrm{mg} / \mathrm{dL})$ (Fig. 18).

Among the adipokines, plasma resistin levels were not altered in either the CD or HFD groups with or without DDT exposure (Fig. 19) whereas HFD groups showed increased plasma leptin levels (HFD: $13444.78 \pm 1270.850 \mathrm{pg} / \mathrm{mL}$ and HFD+DDT: $9405.10 \pm 1640.660 \mathrm{pg} / \mathrm{mL}, \mathrm{p}<0.001)$ (Fig. 20). DDT exposure in both the CD and HFD mice increased plasma adiponectin levels (CD+DDT: 25.14 \pm 1.862 and HFD+DDT: $24.36 \pm 2.404, p=0.049)$ (Fig. 21). 
a.

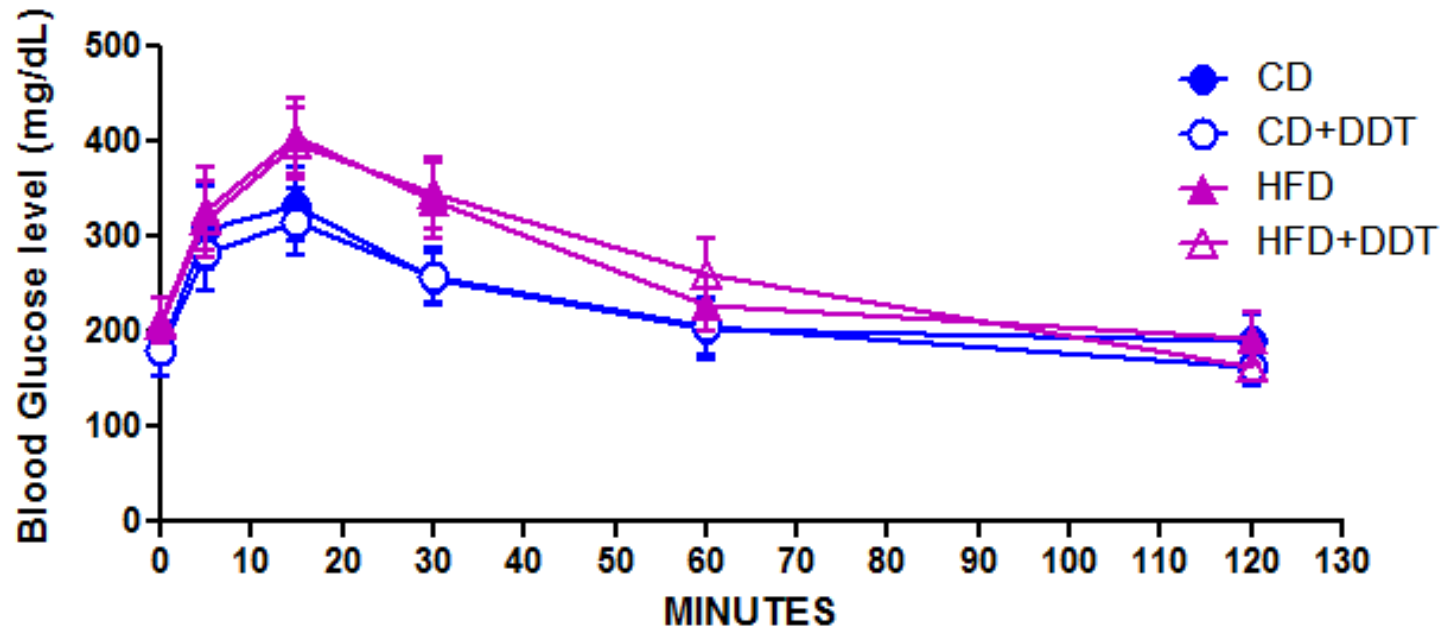

b.

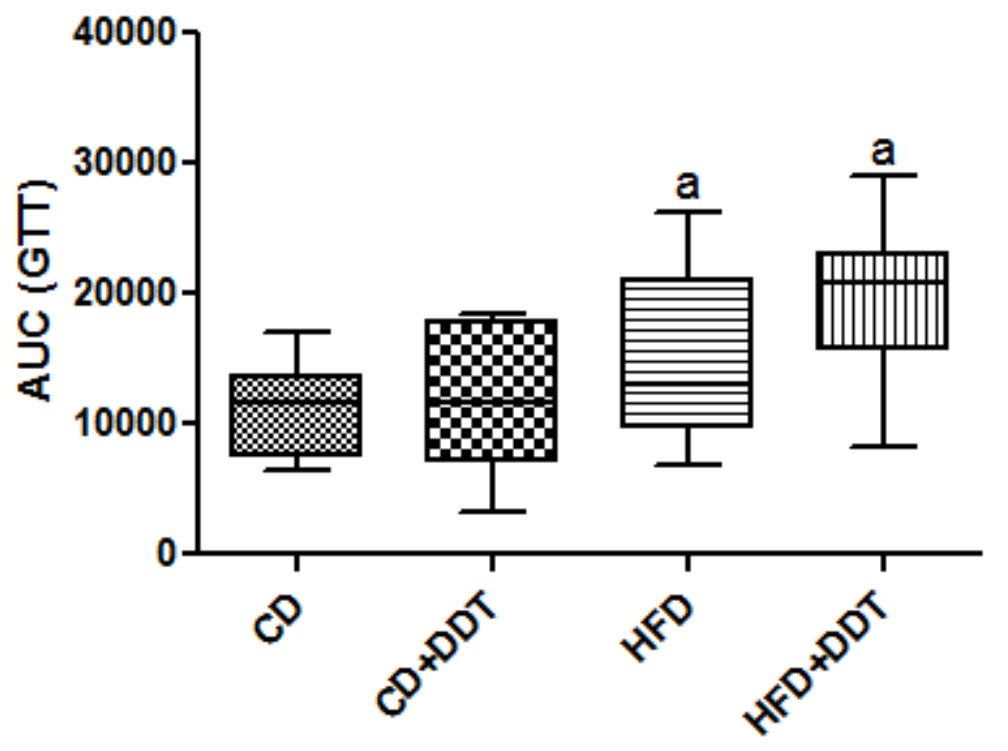

Figure 17. DDT did not affect GTT in either CD- or HFD-fed mice:

a. HFD feeding increased blood glucose levels $(\mathrm{mg} / \mathrm{dL})$ but this was not affected by DDT co-exposure at all the time points starting from time 0 and at $5,15,30$, 60 , and 120 minutes after injecting $1 \mathrm{mg}$ glucose/g body weight. b. The area under the curve (AUC) of the GTT. A hand-held glucometer (ACCU-CHECK Aviva, Roche, Basel, Switzerland) was used to measure the blood glucose levels and data are expressed as mean \pm SEM. Analysis was performed using Two Way ANOVA. (P<0.05, a: due to HFD). 


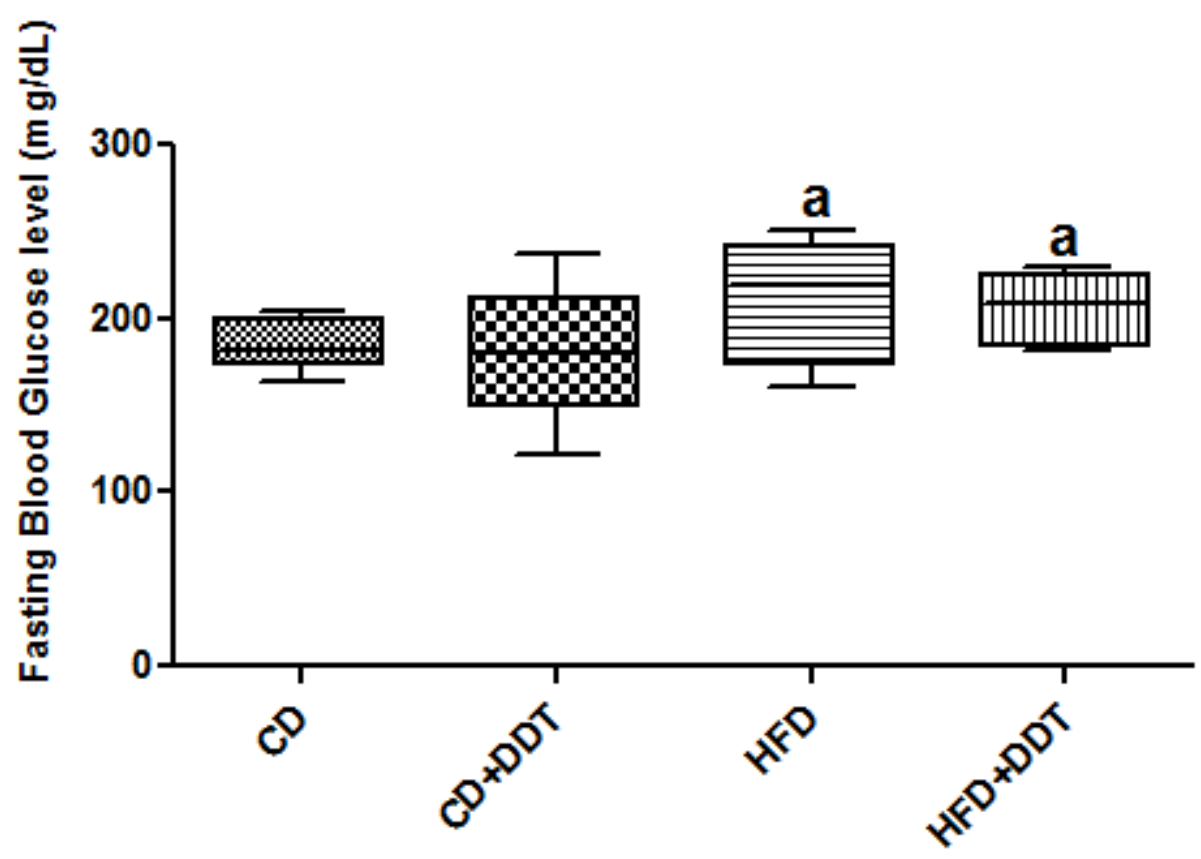

Figure 18. DDT did not affect fasting blood glucose levels:

HFD groups had high fasting blood glucose levels $(p=0.009)$, but DDT had no effect in either CD- or HFD-fed animals. A hand-held glucometer (ACCU-CHECK Aviva, Roche, Basel, Switzerland) was used to measure the fasting blood glucose levels. Data are expressed as mean \pm SEM and Two Way ANOVA was used for statistical analysis. ( $P<0.05$, a: due to HFD). 


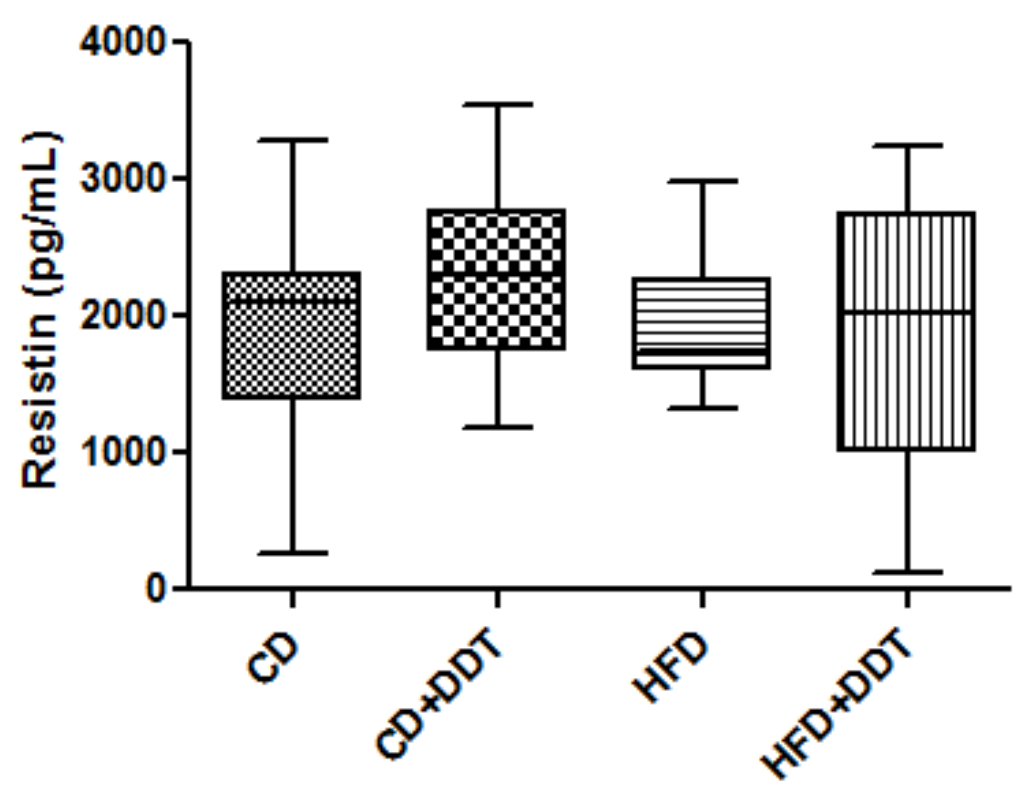

Figure 19. Neither DDT nor HFD affected plasma resistin levels:

Plasma resistin levels were not altered in either the CD or HFD groups with or without DDT exposure. Luminex IS 100 system was used to measure the plasma levels of resistin. Data are expressed as mean \pm SEM and Two Way ANOVA was used for statistical analysis and the data showed no significance. 


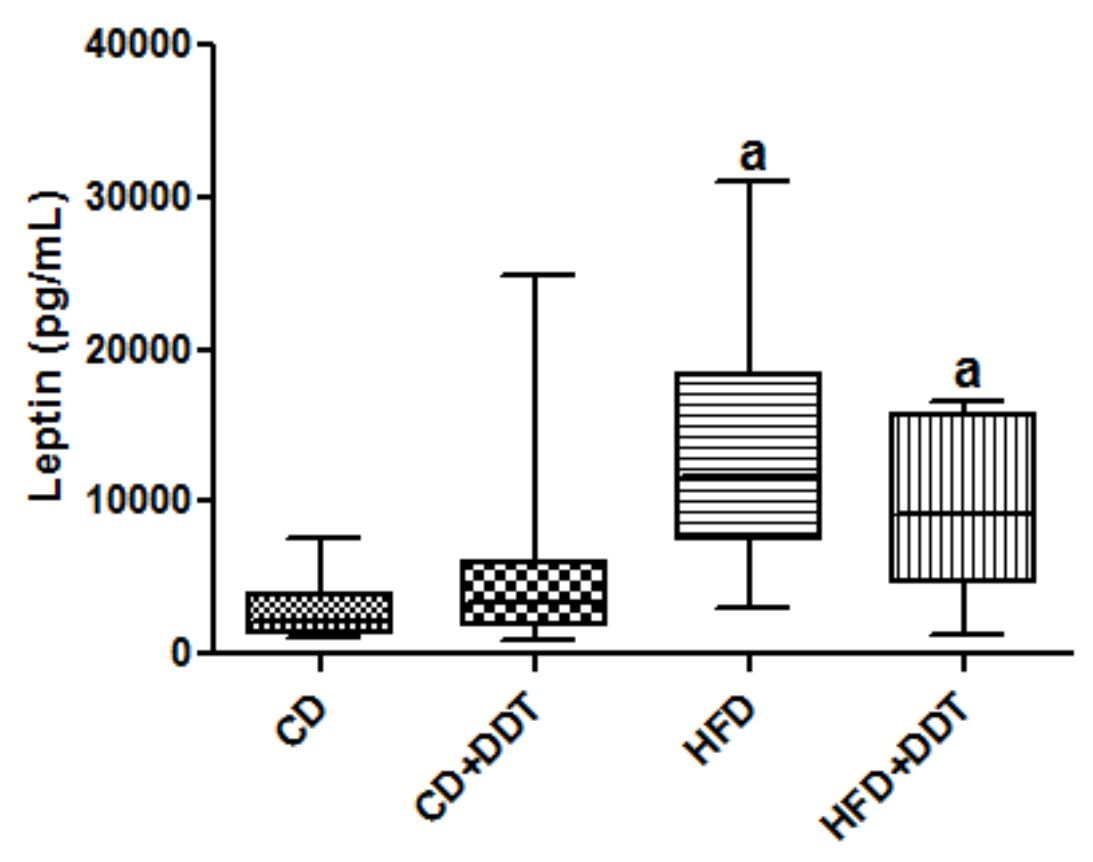

Figure 20. DDT did not affect plasma levels of leptin:

HFD groups showed increased plasma leptin levels $(p<0.001)$ and DDT had no effect. Luminex IS 100 system was used to measure the plasma levels of leptin. Data are expressed as mean \pm SEM and Two Way ANOVA was used for statistical analysis. (P<0.05, a: due to HFD). 


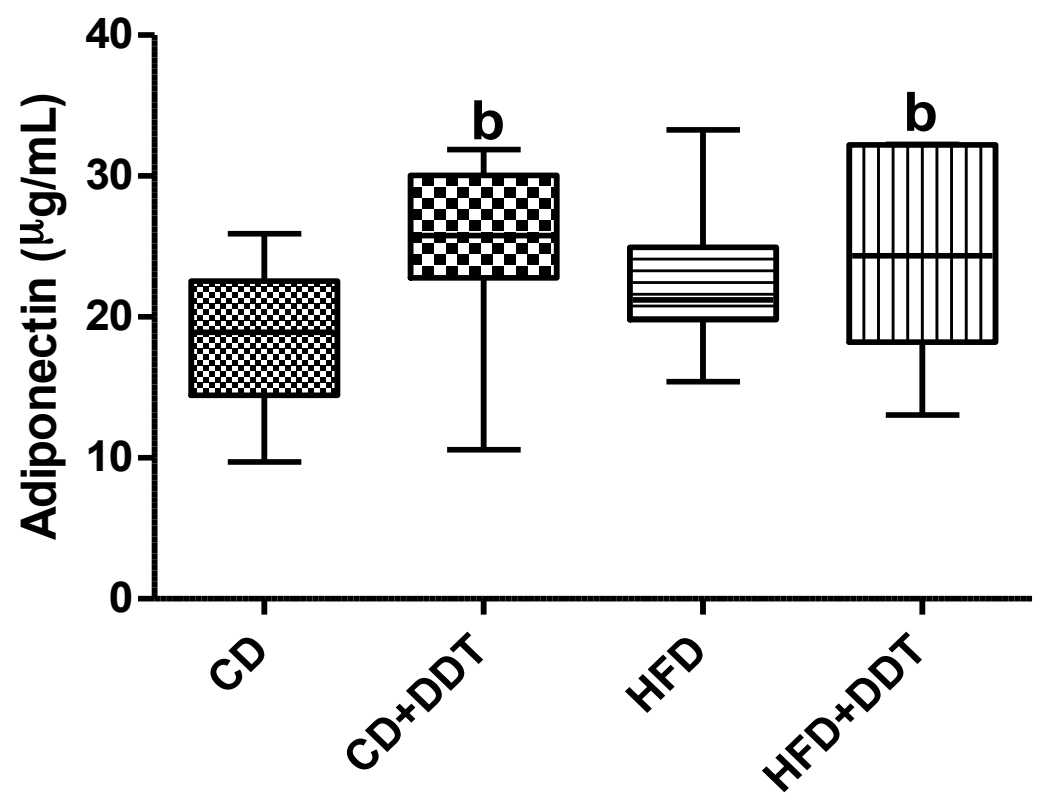

Figure 21. DDT exposure increased plasma levels of adiponectin in CD- and HFD- fed mice:

DDT exposed mice fed CD or HFD had high plasma adiponectin levels $(p=0.049)$ compared to unexposed mice. Luminex IS 100 system was used to measure the plasma levels of adiponectin. Data are expressed as mean \pm SEM and Two Way ANOVA was used for statistical analysis. ( $P<0.05, b$ : due to DDT effect). 
DDT had no effect on plasma cholesterol/triglyceride levels or on hepatic/systemic inflammation.

Plasma cholesterol, triglycerides and high density lipoprotein (HDL) levels were measured using the Piccolo Chemistry Analyzer. HFD feeding increased plasma total cholesterol (HFD: $133.70 \pm 7.89 \mathrm{mg} / \mathrm{dL}$ and HFD+DDT: $106.5 \pm 9.43 \mathrm{mg} / \mathrm{dL}$, $\mathrm{p}<0.001$ ) and HDL levels (HFD: $85.00 \pm 7.16 \mathrm{mg} / \mathrm{dL}$ and HFD+DDT: $78.60 \pm 7.16$ $\mathrm{mg} / \mathrm{dL}, \mathrm{p}=0.012$ ) (Fig. 22\& 23). On the contrary, HFD feeding decreased plasma triglyceride levels (HFD: $43.40 \pm 3.945 \mathrm{mg} / \mathrm{dL}$ and HFD+DDT: $40.71 \pm 4.715 \mathrm{mg} / \mathrm{dL}$, $\mathrm{p}=0.008)($ Fig. 24) .

Plasma cytokine levels and their hepatic mRNA levels were measured using the Luminex IS 100 system and RT-PCR respectively. HFD feeding decreased both plasma IL-6 levels (HFD: $7.74 \pm 14.45 \mathrm{pg} / \mathrm{mL}$ and HFD+DDT: $19.61 \pm 18.65 \mathrm{pg} / \mathrm{mL}$, $\mathrm{p}=0.002$ ) and hepatic IL-6 expression (HFD: $0.60 \pm 0.458$ ) and HFD+DDT: 0.50 $\pm 5.520, p=0.040$ ) in DDT-exposed and unexposed mice (Fig. 25 \&26). On the other hand, DDT exposure decreased plasma tPAI-1 levels in both CD and HFD groups (CD+DDT: 1285.22 \pm 339.512 and HFD+DDT: 951.76 \pm 438.301 , $p=0.047$ ) (Fig. 27). Neither HFD feeding nor DDT exposure affected TNFa plasma and hepatic mRNA levels (Fig. 28 \& 29). Similarly, plasma MCP-1 levels and hepatic MCP-2 mRNA levels were unchanged by diet or DDT exposure (Fig. $30 \& 31)$. The inflammatory cytokines measurements of the unexposed CD-fed mice were higher than those of the HFD-fed mice showing that the control group mice must had some sort of infection that increased their serum and hepatic cytokine levels. 


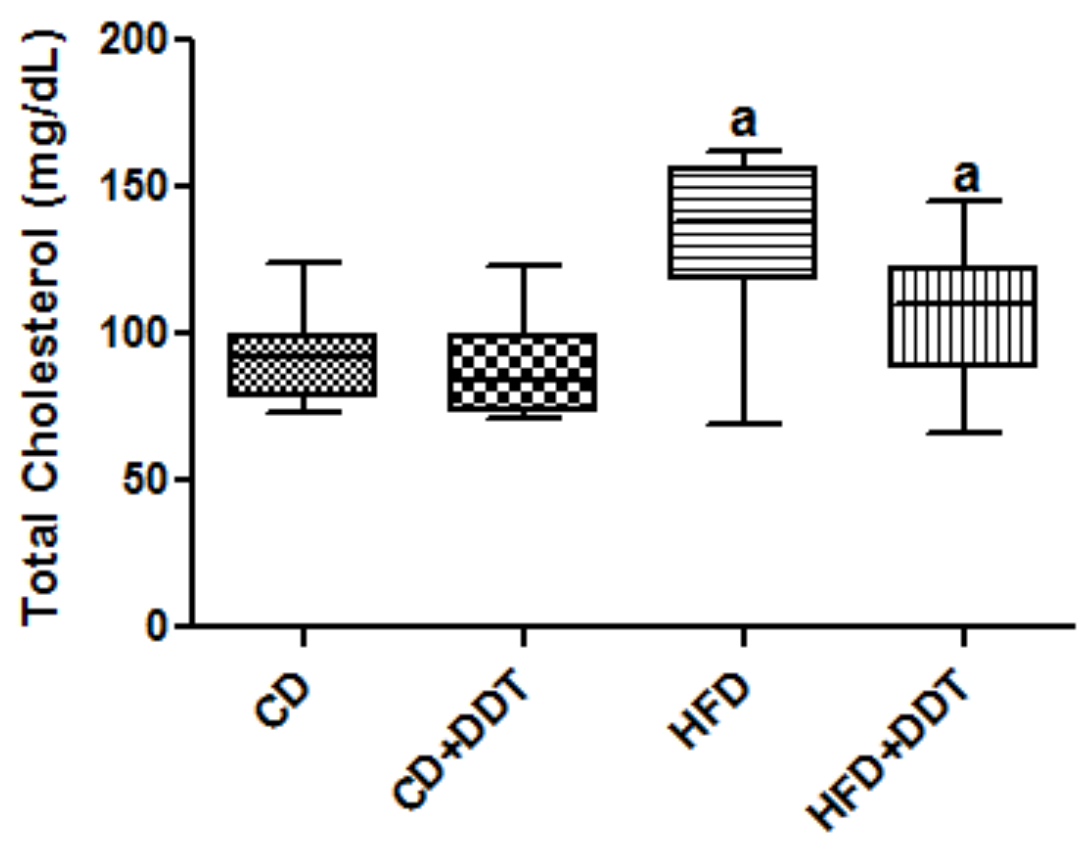

Figure 22. DDT did not affect total cholesterol plasma levels:

HFD fed groups had high cholesterol levels $(p<0.001)$ while DDT had no effect. The Piccolo Xpress Chemistry Analyzer was used to measure plasma levels of total cholesterol and data are expressed as mean \pm SEM. Analysis was performed using Two Way ANOVA. (P<0.05, a: due to HFD). 


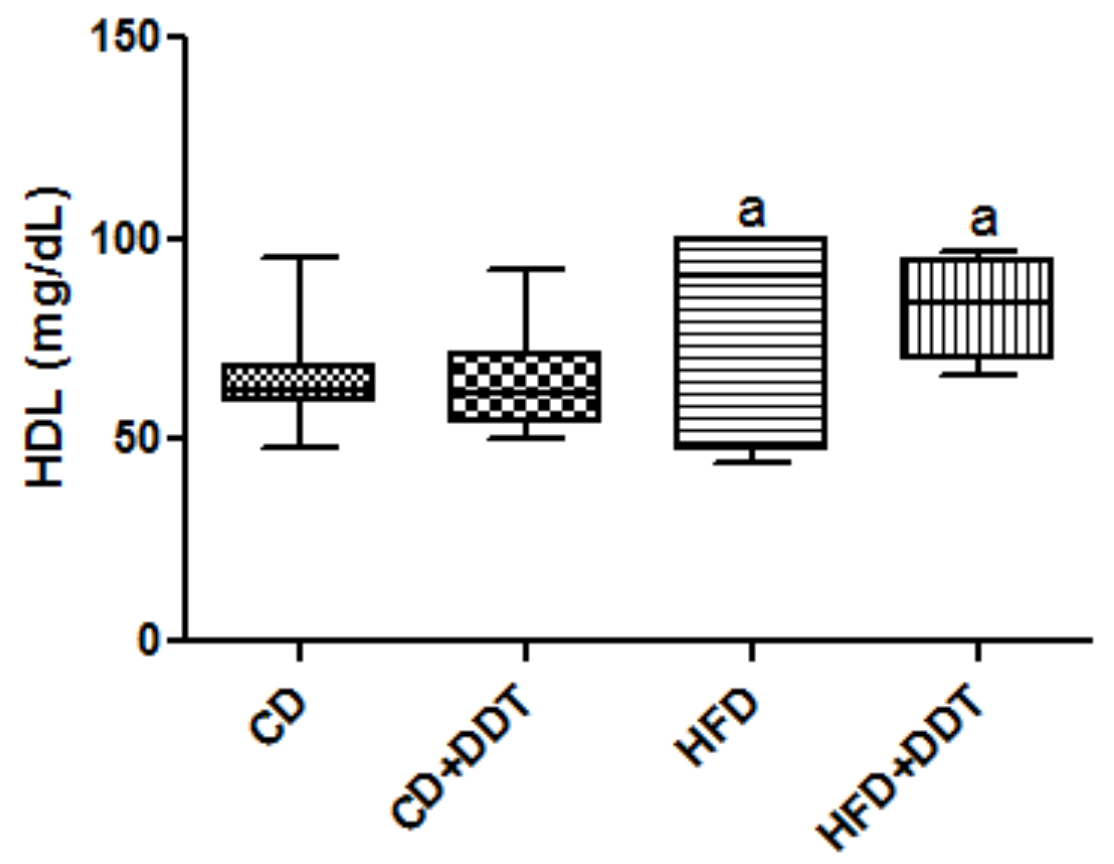

Figure 23. DDT did not affect the plasma levels of HDL:

HFD groups had high HDL plasma levels $(p=0.012)$ while DDT had no effect. The Piccolo Xpress Chemistry Analyzer was used to measure plasma levels of HDL and data are expressed as mean \pm SEM. Analysis was performed using Two Way ANOVA. (P<0.05, a: due to HFD). 


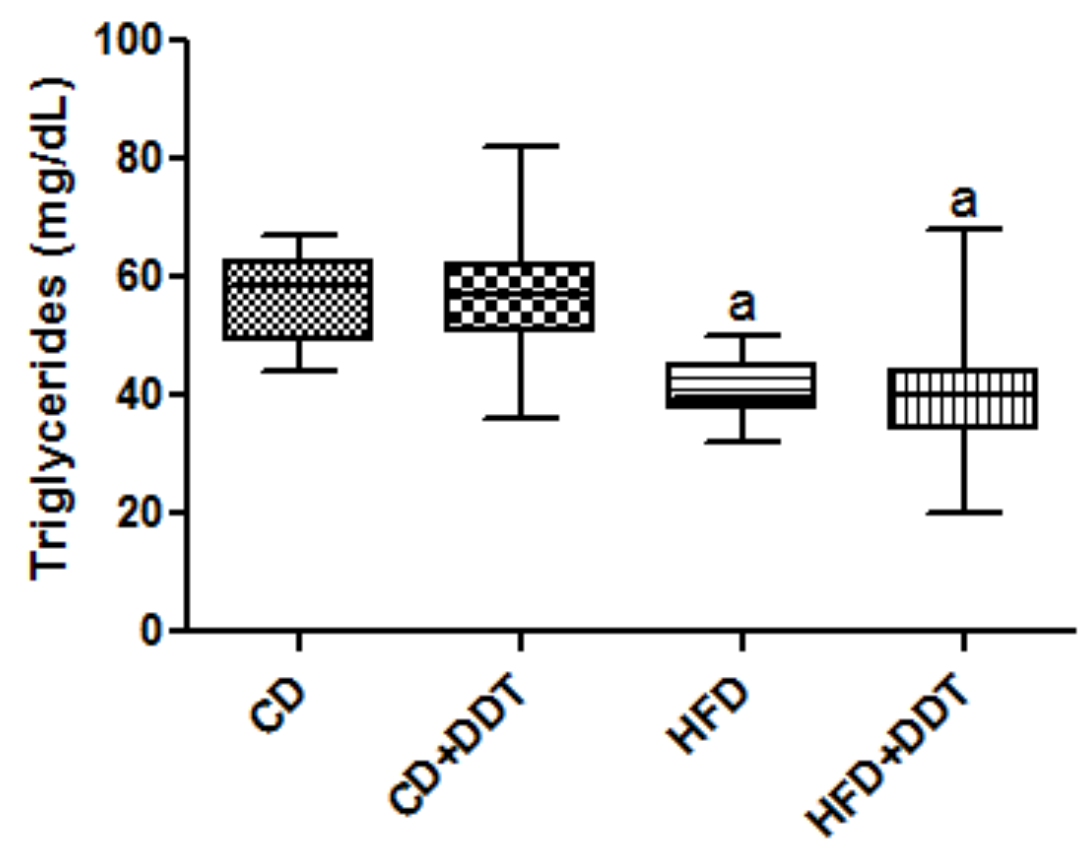

Figure 24. DDT did not affect triglycerides plasma levels:

HFD fed animals had low plasma levels of triglycerides $(p=0.008)$ while DDT had no effect. The Piccolo Xpress Chemistry Analyzer was used to measure plasma levels of triglycerides and data are expressed as mean \pm SEM. Analysis was performed using Two Way ANOVA. ( $P<0.05$, a: due to HFD). 


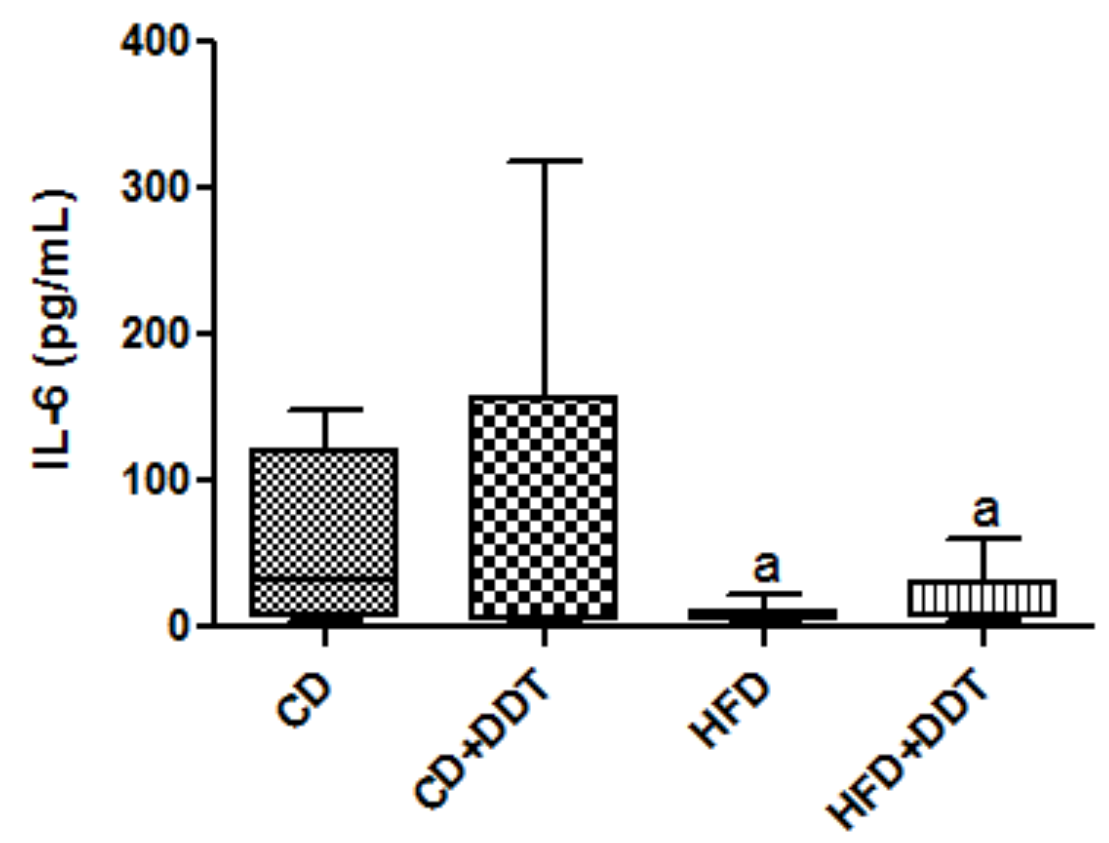

Figure 25. DDT did not affect IL-6 plasma levels:

HFD-fed mice had low plasma IL-6 levels $(p=0.002)$ while DDT had no effect. Luminex IS 100 system was used to measure the plasma levels of IL-6. Data are expressed as mean \pm SEM and Two Way ANOVA was used for statistical analysis. ( $P<0.05$, a: due to HFD). 


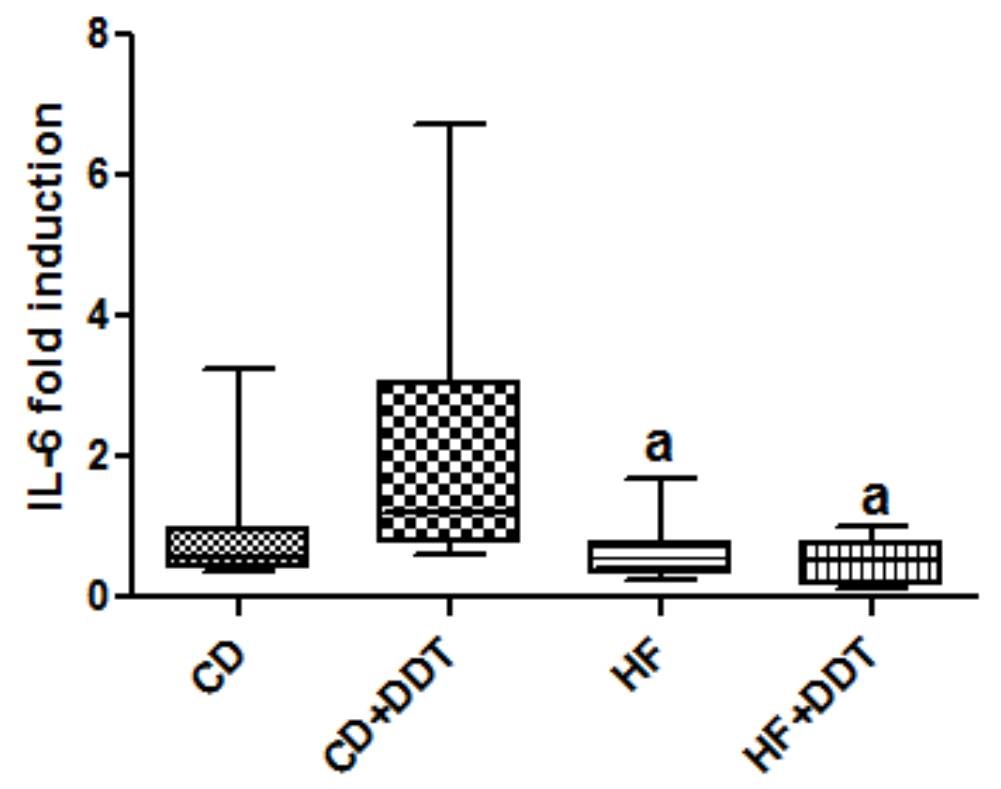

Figure 26. DDT did not affect hepatic IL-6 expression:

Hepatic IL-6 expression was decreased in HFD fed groups $(p=0.040)$ while DDT had no effect. Real-time PCR was used for levels of expression measurement. Data are expressed as mean \pm SEM and statistical analysis was performed using Two Way ANOVA. (P<0.05, a: due to HFD). 


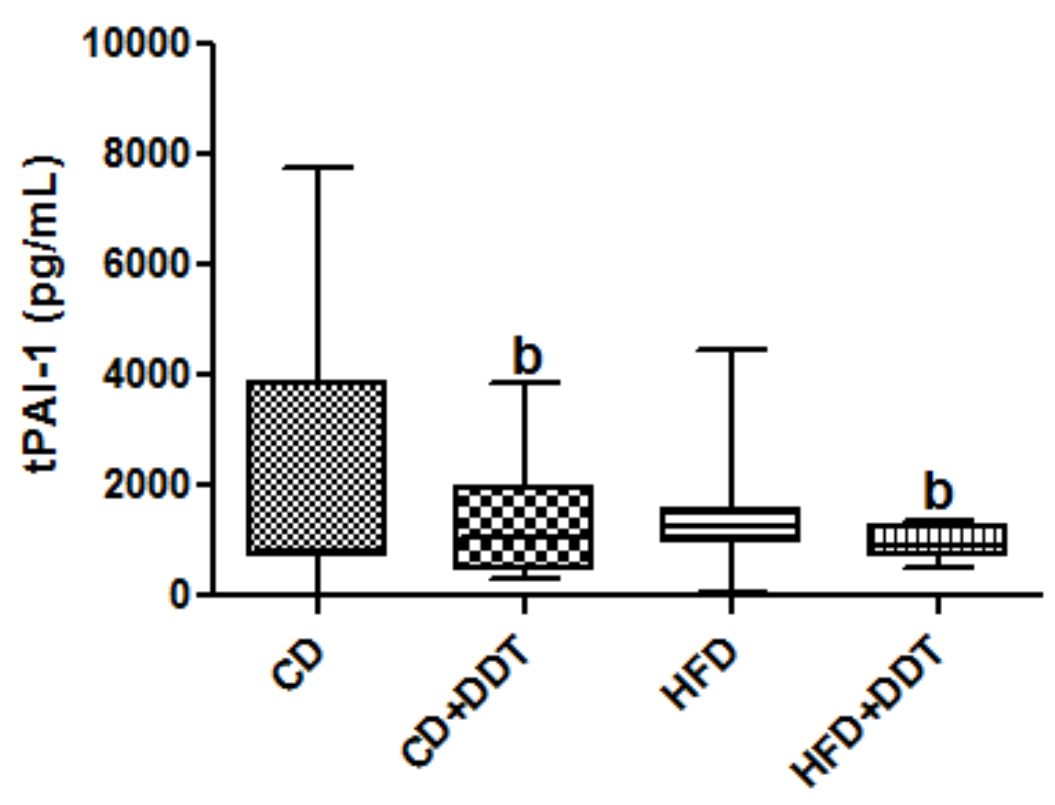

Figure 27. DDT decreased plasma levels of tPAI-1:

DDT exposure decreased plasma tPAI-1 levels in both CD and HFD groups $(p=0.047)$. Luminex IS 100 system was used to measure the plasma levels of tPAI-1. Data are expressed as mean \pm SEM and Two Way ANOVA was used for statistical analysis. $(P<0.05$, a: due to HFD, b: due to DDT effect and c: interaction between HFD and DDT 


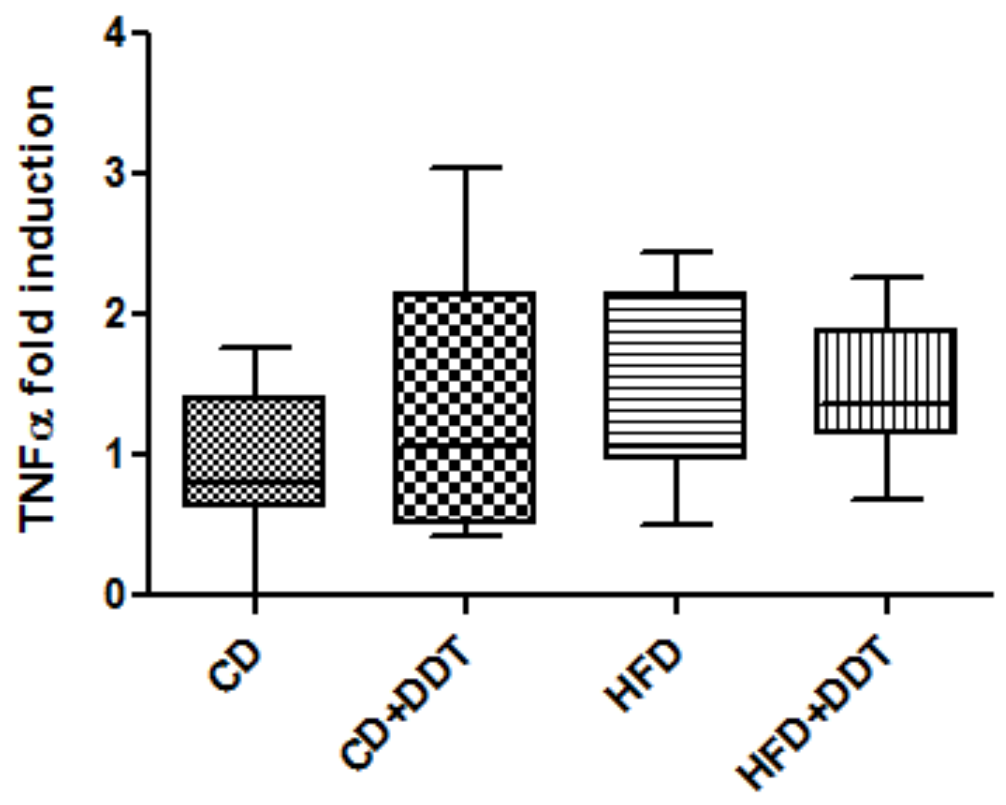

Figure 28. Neither HFD nor DDT affected the TNFa hepatic expression:

Neither DDT nor HFD affected the TNFa hepatic expression. Real-time PCR was used for levels of expression measurement. Data are expressed as mean \pm SEM and statistical analysis was performed using Two Way ANOVA and the data showed no significance. 


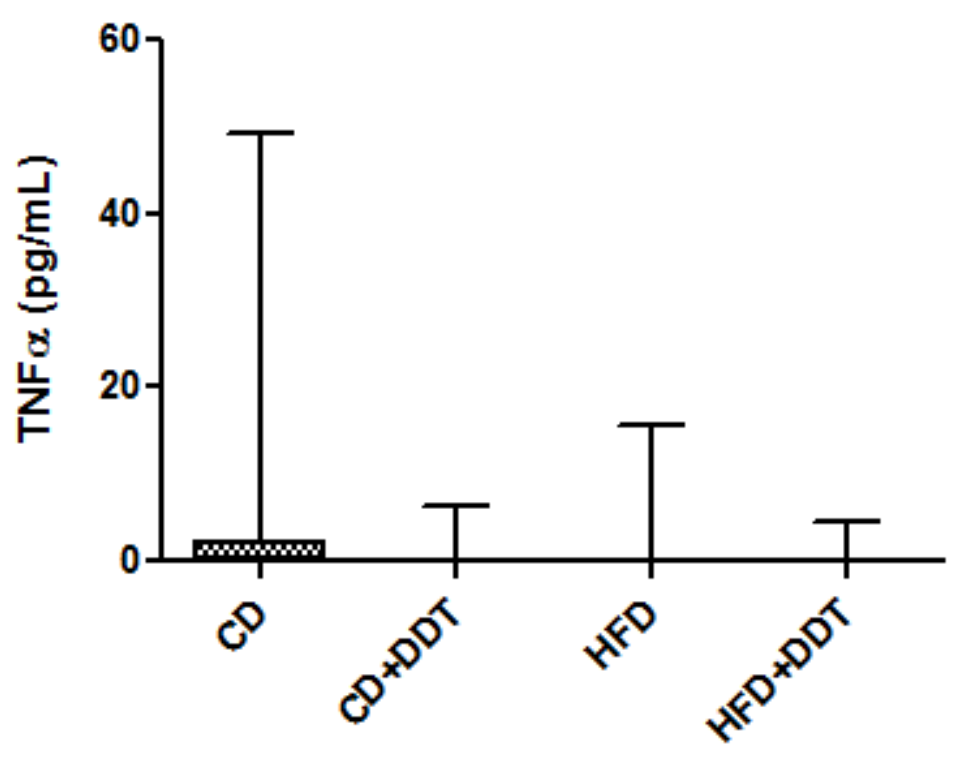

Figure 29. Neither HFD nor DDT affected TNFa plasma levels:

Neither HFD feeding nor DDT exposure affected TNFa plasma levels. Luminex IS 100 system was used to measure the plasma levels of TNFa. Data are expressed as mean \pm SEM and Two Way ANOVA was used for statistical analysis and the data showed no significance. 


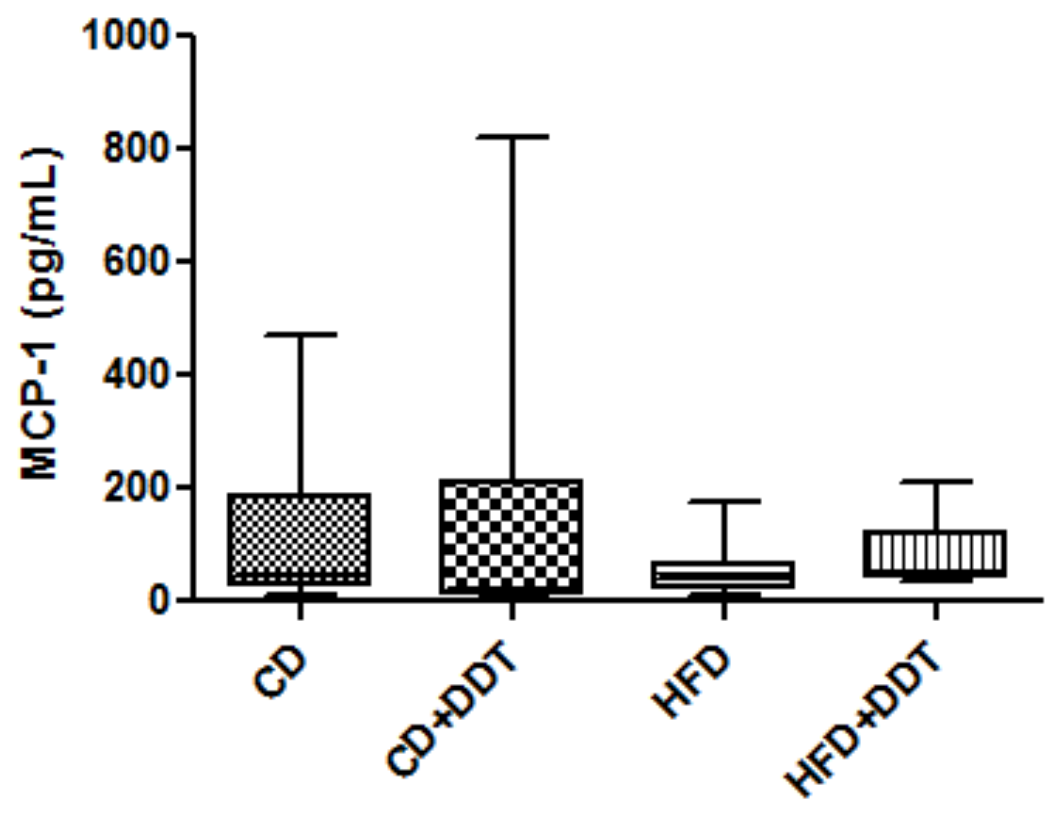

Figure 30. Neither HFD nor DDT affected MCP-1 plasma levels:

MCP-1 plasma levels were not affected by either HFD or DDT. Luminex IS 100 system was used to measure the plasma levels of MCP-1. Data are expressed as mean \pm SEM and Two Way ANOVA was used for statistical analysis and the data showed no significance. 


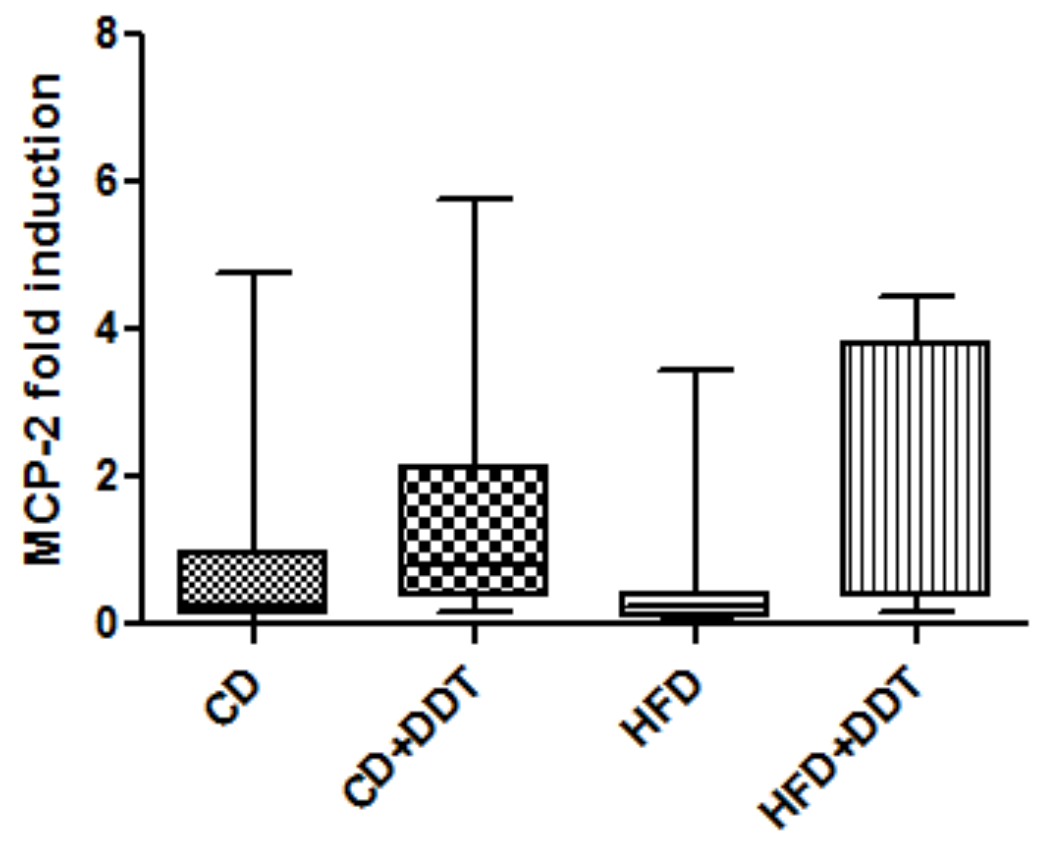

Figure 31. Neither HFD nor DDT affected hepatic MCP-2 expression:

MCP-2 liver expression levels were not affected by either HFD or DDT. Real-time PCR was used for levels of expression measurement. Data are expressed as mean \pm SEM and statistical analysis was performed using Two Way ANOVA and the data showed no significance. 


\section{Effects of DDT on PPARa and LXR target genes.}

Hepatic mRNA levels of PPARa target genes, namely carnitine palmitoyltransferase I (CPT1a), an enzyme that regulates mitochondrial fatty acid beta-oxidation and Cyp4a10, an enzyme that regulates peroxisomal fatty acid oxidation were measured (74). DDT exposure resulted in decreased hepatic expression of CPT1A mRNA irrespective of the diet type given (CD+DDT: $0.31 \pm 0.110$ and HFD+DDT: $0.35 \pm 0.131, p<0.001)$, suggesting that fatty acid oxidation was compromised in DDT-exposed mice (Fig. 32). Likewise, hepatic Cyp4a10 mRNA expression was lowered in both the DDT-exposed groups (CD+DDT: $0.76 \pm 0.436$ and HFD+DDT: $0.97 \pm 0.52, p=0.005)$. However, HFD

alone resulted in increased Cyp4a10 mRNA expression $(0.77 \pm 0.44, p=0.006)$ and there was a significant interaction between HFD and HFD+DDT $(p=0.017)$ (Fig. 33).

Hepatic mRNA levels of liver-X-receptor (LXR) target genes were also evaluated, including fatty acid synthase (FAS), an enzyme that catalyzes fatty acid synthesis, and CD36, a fatty acid binding protein required for cellular fatty acid uptake (75). HFD consumption led to downregulation of hepatic FAS in both DDT-exposed and unexposed mice (HFD: $0.40 \pm 0.242$ and HFD+DDT 0.25 \pm 0.29 , $p=0.001)$ (Fig. 34). On the other hand, DDT exposure in CD-fed mice increased hepatic CD36 (2.351 $\pm 0.598, p=0.031)$. Likewise, HFD consumption also resulted in increased of hepatic CD36 (HFD: $2.518 \pm 0.567$ and HFD+DDT: $3.925 \pm 0.678$, $\mathrm{p}=0.017)($ Fig. 35). 


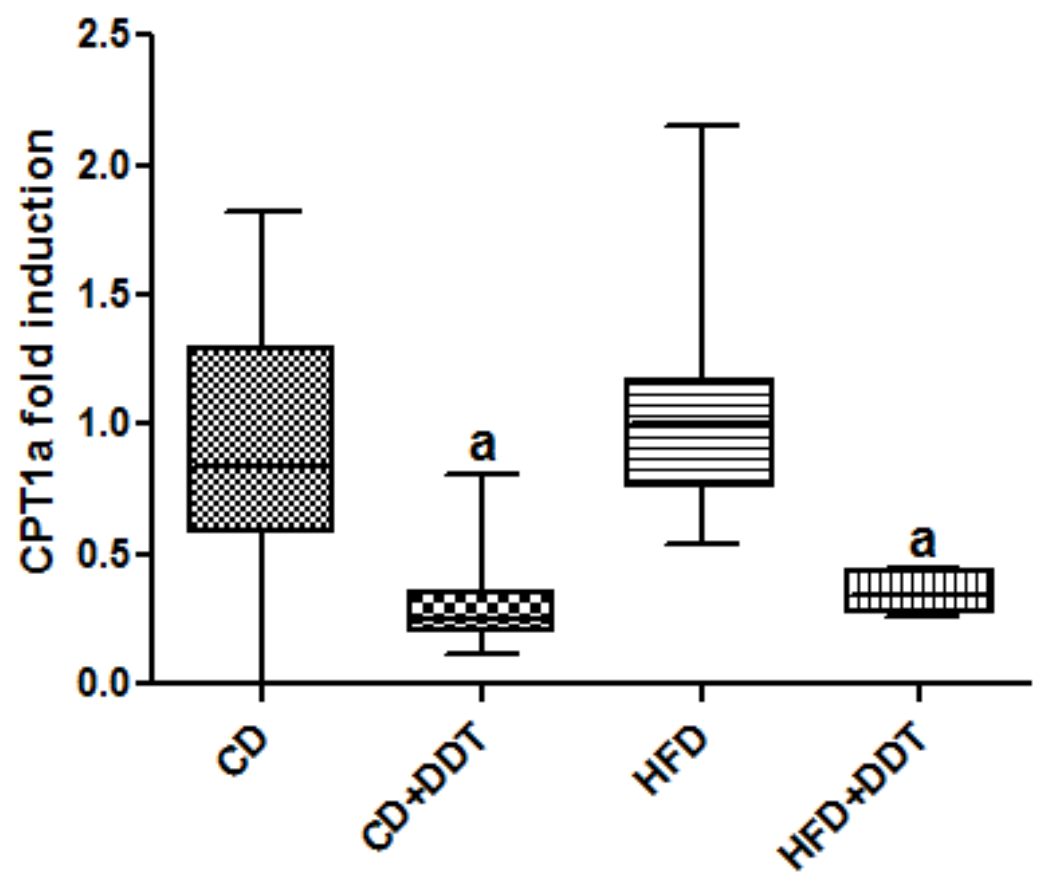

Figure 32. DDT decreased hepatic expression of CPT1a in both CD- and HFD- fed groups:

DDT co-exposed animals fed either CD or HFD had low expression of hepatic CPT1a $(p<0.001)$. Real-time PCR was used for levels of expression measurement. Data are expressed as mean \pm SEM and statistical analysis was performed using Two Way ANOVA. ( $\mathrm{P}<0.05$, a: due to HFD). 


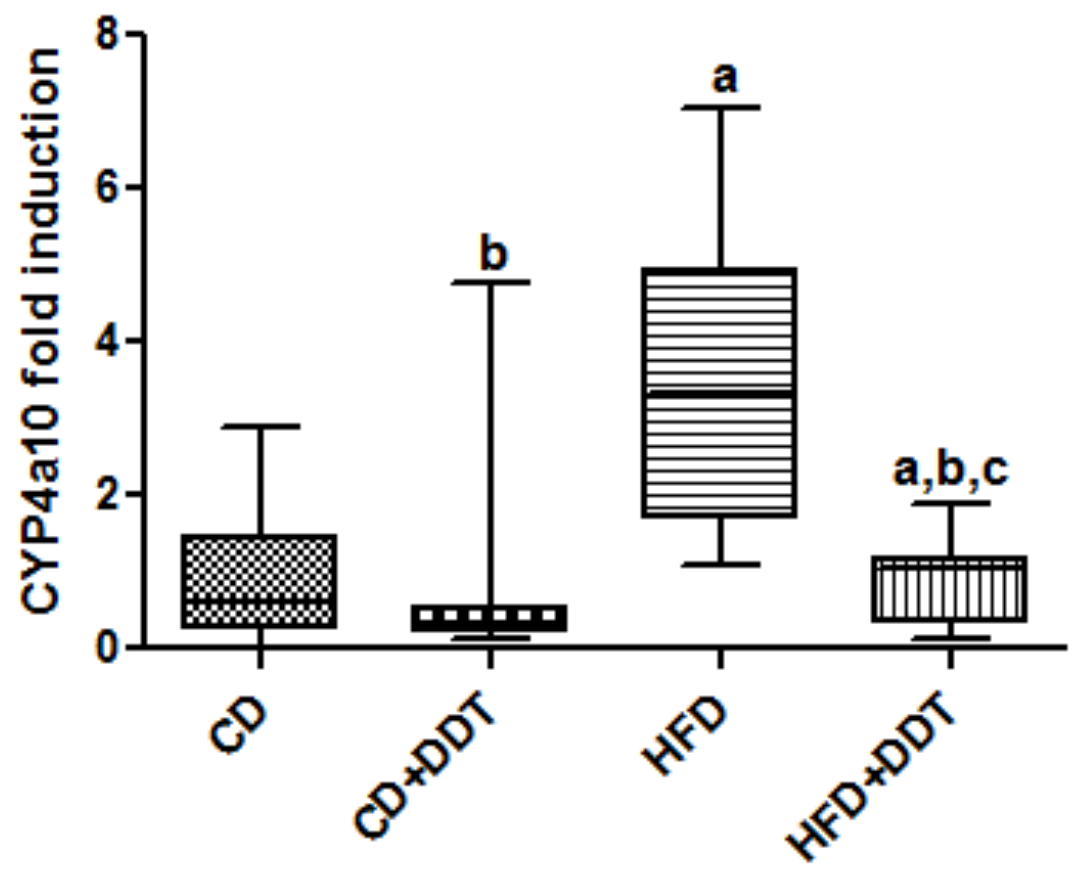

Figure 33. DDT decreased hepatic expression of Cyp4a10 in both CD- and HFD- fed groups:

Hepatic Cyp4a10 expression was lowered in both the DDT-exposed groups $(p=0.005)$. HFD alone group had in high Cyp4a10 expression $(p=0.006)$ and there was a significant interaction between HFD and HFD+DDT $(p=0.017)$. Realtime PCR was used for levels of expression measurement. Data are expressed as mean \pm SEM and statistical analysis was performed using Two Way ANOVA. ( $P<0.05$, a: due to HFD, b: due to DDT effect and c: interaction between HFD and DDT). 


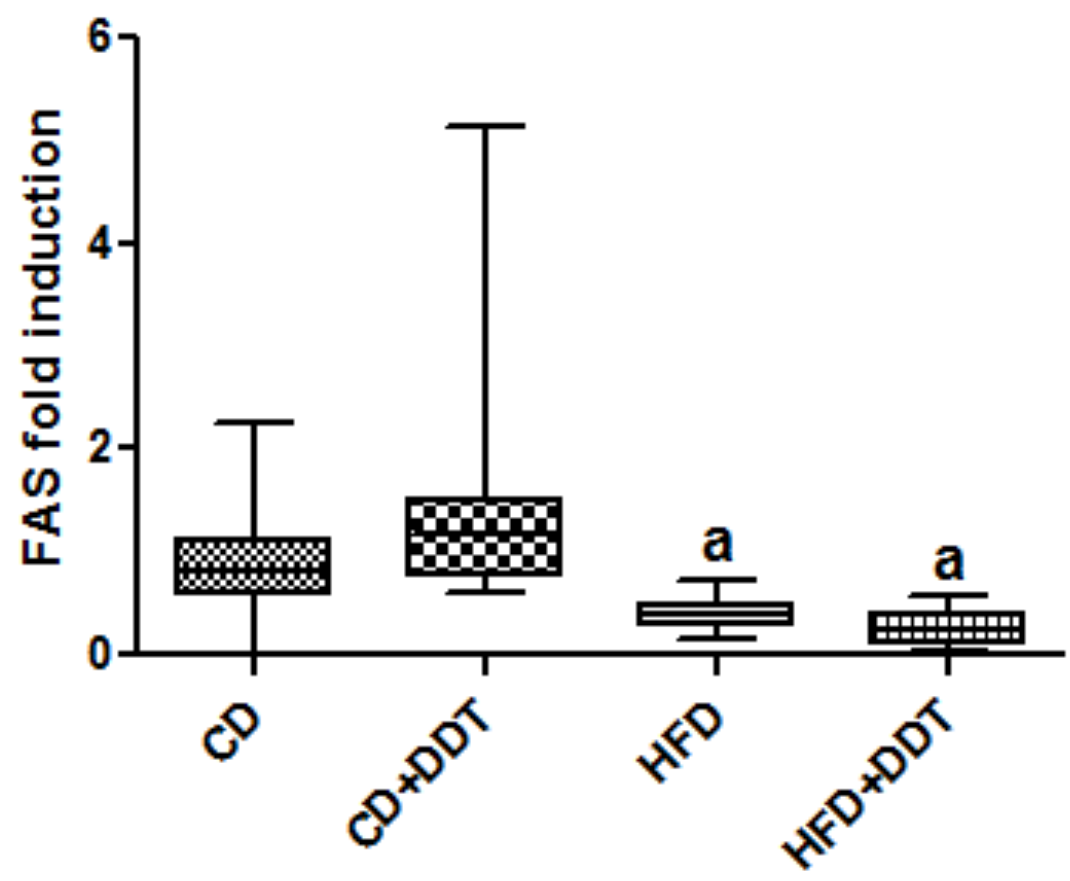

Figure 34. HFD decreased the hepatic expression of FAS:

HFD-fed groups had low levels of hepatic FAS $(p=0.001)$ while DDT had no effect. Real-time PCR was used for levels of expression measurement. Data are expressed as mean \pm SEM and statistical analysis was performed using Two Way ANOVA. (P<0.05, a: due to HFD). 


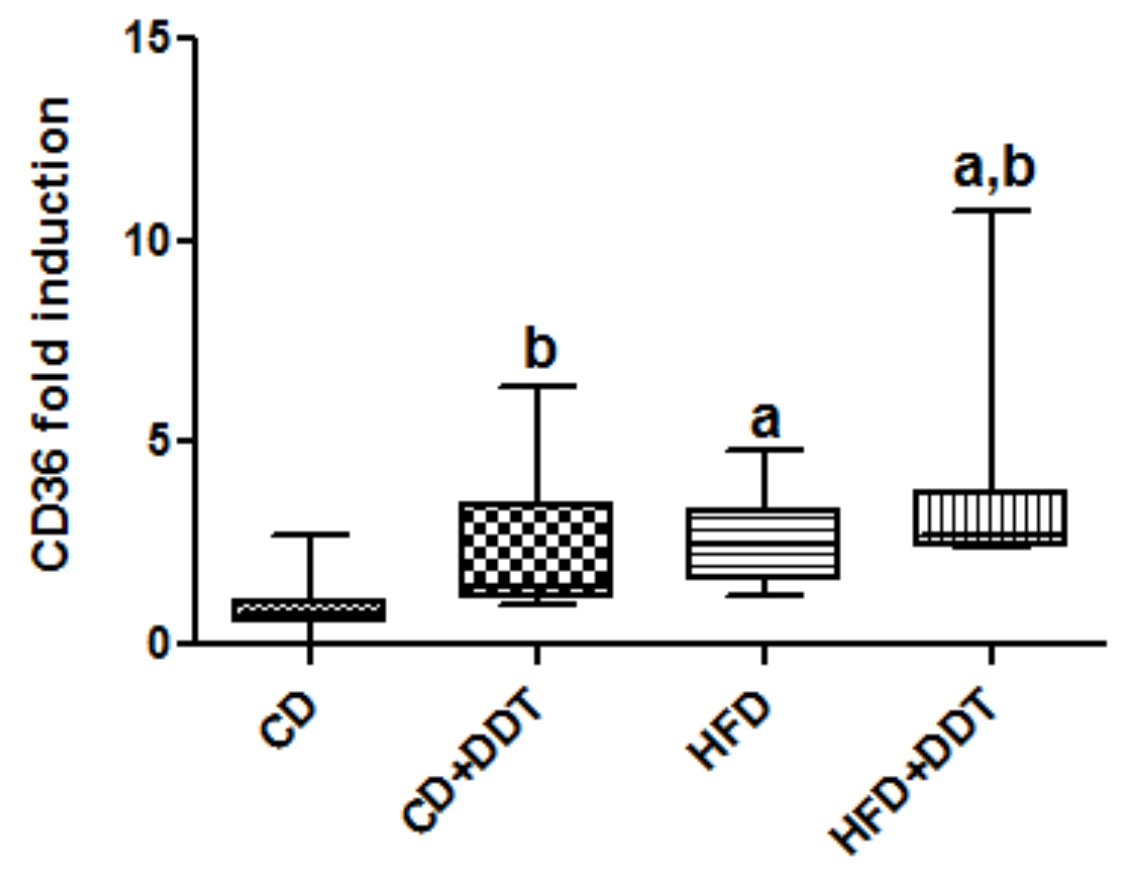

Figure 35. DDT and HFD increased the hepatic expression of CD36:

Hepatic expression of CD36 was increased with DDT $(p=0.031)$ and HFD $(p=0.017)$. Real-time PCR was used for levels of expression measurement. Data are expressed as mean \pm SEM and statistical analysis was performed using Two Way ANOVA. ( $P<0.05$, a: due to HFD, b: due to DDT effect). 


\section{DDT exposure induced Cyp2b10, a CAR target gene.}

Hepatic expression of Cyp2b10, a CAR target gene, was measured to determine if DDT activated CAR in these animals. DDT exposure led to increased of Cyp2b10 in CD-fed mice $(83.82 \pm 24.474, p=0.026)$, indicating CAR activation in these animals (Fig. 36). Likewise, HFD consumption also resulted in increased of Cyp2b10 (73.65 $\pm 24.474, p=0.049)$. Interestingly, DDT co-exposure did not potentiate Cyp2b10 increased by HFD. Rather, there was a significant interaction between HFD and DDT $(p=0.036)$, suggesting that DDT co-exposure in HFD-fed mice displayed downregulated Cyp2b10 (HFD+DDT: 42.404 \pm 29.252$)$.

Hepatic expression of Cyp3a11, a PXR target gene, was also measured to assess PXR activation in these animals. DDT exposure did not alter Cyp3a11 expression in CD-fed mice (Fig. 37). However, HFD feeding resulted in increased of hepatic Cyp3a11 but DDT had no effect on this (HFD: $5.79 \pm 0.803$ and HFD+DDT: $4.38 \pm 0.959, p<0.001)$. The results indicated that DDT did not activate hepatic PXR in these animals. 


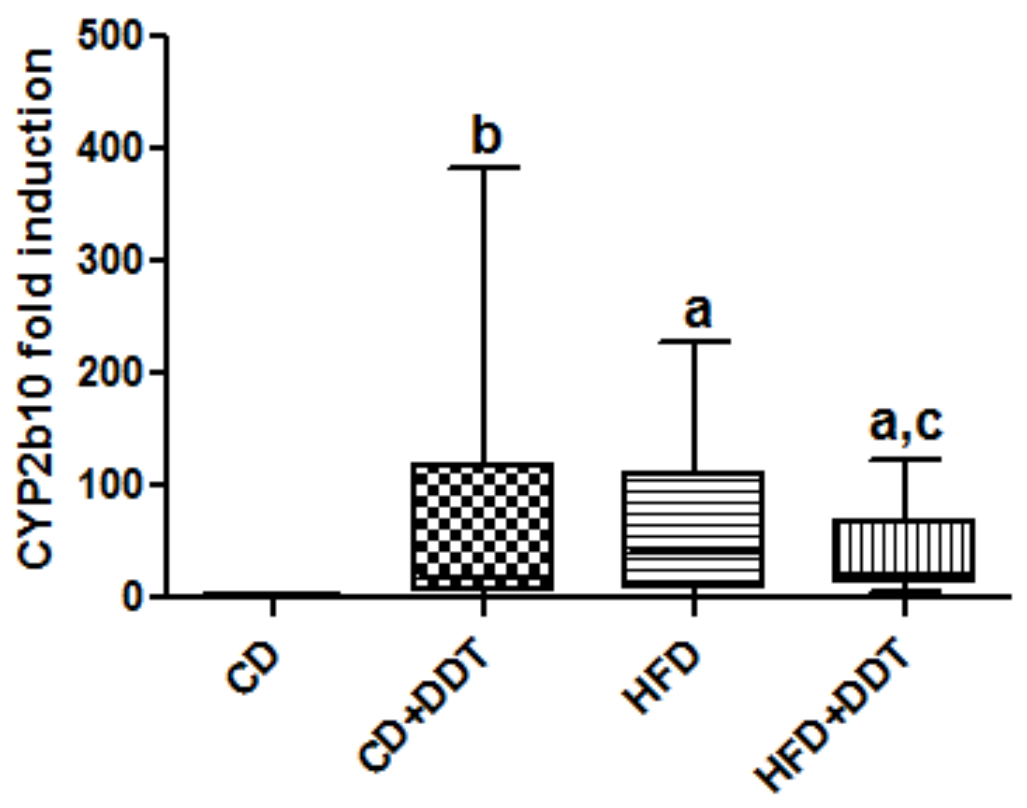

Figure 36. DDT and HFD increased the hepatic expression of Cyp2b10:

DDT exposure increased Cyp2b10 in CD- $(p=0.026)$ and HFD- fed mice $(p=0.049)$. There was a significant interaction between HFD and DDT $(p=0.036)$.

Real-time PCR was used for levels of expression measurement. Data are expressed as mean \pm SEM and statistical analysis was performed using Two Way ANOVA. ( $P<0.05$, a: due to HFD, b: due to DDT effect and c: interaction between HFD and DDT). 


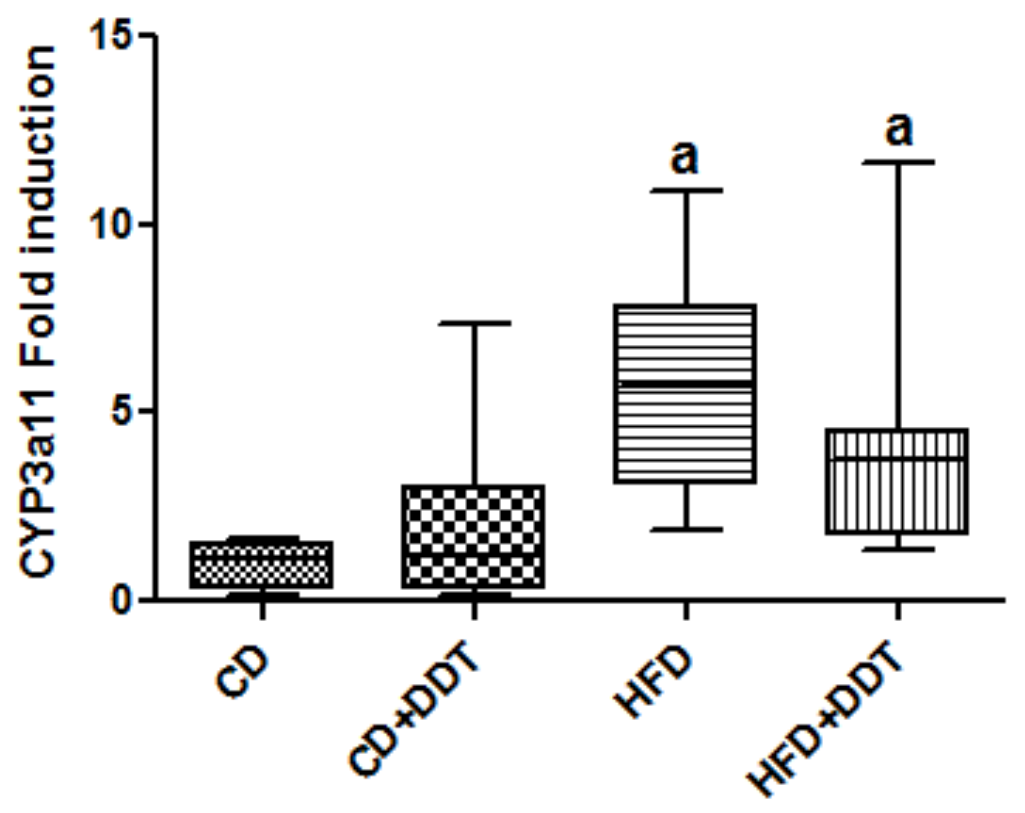

Figure 37. HFD increased the hepatic expression of Cyp3a11:

HFD increased the hepatic Cyp3a11 expression $(p<0.001)$ while DDT exposure did not alter Cyp3a11 expression. Real-time PCR was used for levels of expression measurement. Data are expressed as mean \pm SEM and statistical analysis was performed using Two Way ANOVA. ( $P<0.05$, a: due to HFD). 


\section{DISCUSSION}

The in vivo study on DDT demonstrated that DDT did not worsen obesity or liver injury caused by HFD feeding. However, the DDT-exposed mice displayed lower plasma ALT levels, higher plasma adiponectin levels and no insulin resistance. DDT exposure also lowered the fat tissue weight in HFD-fed mice. Additionally, there was no evidence of either hepatic or systemic inflammation observed with DDT exposure. Furthermore, DDT appeared to be a CAR activator in our study. These results indicated that DDT exposure appeared to be protective from DIO, which is counter-intuitive to our initial hypothesis. However, these findings are not surprising, given the fact that CAR activation has been closely related to protect against insulin resistance and obesity-related disorders (76). In terms of dosage, we used a cumulative dose of $100 \mathrm{mg} / \mathrm{kg}$. This was designed to be well below the $\mathrm{LD}_{50}$ of $\mathrm{DDT}$ which was reported to range from $152.3-1466 \mathrm{mg} / \mathrm{kg} /$ day to prevent acute toxicity (60). It is possible that using a dose $>100 \mathrm{mg} / \mathrm{kg}$ may have resulted in different outcomes than those observed in this study.

DDT exposure did not affect body weight or food consumption. The protective effect of DDT in terms of adiposity was seen in the HFD-fed animals that displayed lower fat weight and decreased liver weights. DDT exposure also resulted in lower plasma ALT levels. Plasma adiponectin levels were also higher in the DDT-exposed mice irrespective of the diet type. Adiponectin is an adipokine that regulates glucose and fatty acid catabolism and its levels are 
inversely proportional to body fat composition. Increased adiponectin levels observed in DDT-exposed mice may be a plausible reason for a decrease in fat weight in CD-fed mice. Adiponectin also has anti-inflammatory function, which is consistent with the absence of inflammation seen in the liver tissues of the DDTexposed mice (77). Moreover, DDT exposure also decreased plasma tPAI-1 levels, confirming the absence of liver injury. DDT exposure did not affect leptin levels. Leptin, another adipokine, regulates hunger and satiety and since its levels remained unaltered, food consumption was not significantly affected as well. Insulin resistance has been linked to high resistin levels in obese mice (78). Consistent with our results that showed that DDT did not cause insulin resistance, DDT-exposed animals' plasma resistin levels were not affected.

DDT exposure did not contribute to elevated plasma cholesterol and HDL. Hepatic expression of the lipogenic gene FAS was not affected by DDT, indicating that DDT did not cause lipogenesis in these animals. Paradoxically, another lipogenic gene, CD36, required for fatty acid uptake by cells was increased. CD36 plays an important role in the immune system, coagulation cascade, atherosclerosis and lipid metabolism (79). In lipid metabolism, CD36 binds HDL, LDL and VLDL and it also works as a scavenger for oxidized LDL in macrophages $(80,81)$. PPARa targets, CPT1a and Cyp4a10, were downregulated in DDT-exposed mice indicating that the fat burning machinery was compromised in these animals. Surprisingly, this did not cause nor worsen steatosis, and one of the reasons could be the protective effects exerted by CAR activation. Malabsorption of dietary fat in the HFD+DDT co- 
exposed mice may be another explanation for the absence of steatosis in this group.

DDT induced Cyp2b10 in CD-fed mice, indicating CAR activation as mentioned earlier. In contrast, DDT did not activate PXR, since Cyp3a11 was not induced. CAR activation is consistent with insulin sensitivity and decreased lipogenesis, which is concordant with our findings. The transient transfection studies on HepG2 cells mentioned previously demonstrated that DDT did not activate murine CAR. However, Mutoh et al showed the ability of phenobarbital to activate CAR indirectly through inhibition of the epidermal growth factor receptor (EGFR). We speculate that DDT might be acting though the same mechanism as phenobarbital to activate CAR indirectly, and this does not necessitate a direct ligand interaction $(82,83)$. CAR activation was also shown to decrease PPARa expression and hence, downregulation of its target genes (CPT1a and Cy4a10) and this was also observed in our animals $(76,84,85)$. In addition, previous studies demonstrated that phenobarbital, a CAR activator, downregulated CPT1 levels in mice but this was not seen in CAR knockout mice, which further supports our findings (82).

Additionally, there was no evidence of either hepatic or systemic inflammation observed with DDT exposure or unexposed animals. In fact, the measured levels of inflammatory cytokines in the serum and hepatic were higher in CD-fed animals, which indicates that these animals had some sort of infection. Therefore, they study should be repeated with the unexposed CD-fed animals only in order to get valid evaluation of the results from the other groups. Another 
limitations in this study is that we were using a DIO model to investigate DDT hepatic toxicity in mice. However, humans are exposed to different chemicals simultaneously. Another alternative approach is to investigate the effects of DDT in a mixture of chemicals or using another hit apart from HFD. Choosing a higher dose and a more chronic exposure is another potential approach.

In conclusion, DDT did not decrease body weight or food consumption despite downregulation of PPARa target genes. The HFD+DDT group of mice also exhibited similar food consumption patterns as HFD group but showed lower adiposity. Moreover, DDT did not cause insulin resistance or worsen NAFLD. Despite reducing the expression of fatty acids $\beta$-oxidation genes, DDT improved steatosis in HFD-fed mice. However, DDT did not improve diabetes caused by HFD feeding. Furthermore, DDT appeared to contribute to these effects through CAR activation. However, further investigation is required in terms of CAR direct vs. indirect activation and if using higher doses could consequently activate PXR as well. 


\section{SUMMARY}

NAFLD is the most common cause of liver disease worldwide. Toxicant associated steatohepatitis (TASH) is a recently identified form of non-alcoholic fatty liver disease and it is mainly associated with chemical exposure. However, the mechanisms by which environmental chemicals contribute to liver disease are not well-studied due to the lack of manifestations and chemical indicators in addition to a comprehensive lists of chemicals.

Three hundred seventy one studies archived in federal databases ToxRefDB and CEBS linked 123 unique environmental chemicals to fatty liver disease in rodents. Pesticides composed almost $44 \%$ of these chemicals. Moreover, the compounds found associated with ALT elevation in the 2003-2004 NHANES were 3 metals and 8 OCPs in addition to more than 200 pesticides identified from the ToxCast DB database. Pesticides have been associated with NAFLD in many studies and we therefore decided to study the role of some pesticides on NAFLD.

Most of the eight compounds studied activated hPXR, mPXR and hCAR and DDT was the strongest activator. Moreover, the main metabolite of DDT, DDE, was detected in considerable concentrations in the NHANES participants with high ALT levels. Therefore, DDT was selected to be studied in a DIO mice model. 
Upon DDT exposure (12 weeks, $100 \mathrm{mg} / \mathrm{kg}$ ), Cyp2b10 (CAR target) was increased in control diet-fed mice. DDT did not increase Cyp3a11 (PXR target) in any group. DDT did not decrease body weight or food consumption, but HFD+DDT mice showed lower adiposity. DDT did not cause insulin resistance or worsen NAFLD.

In conclusion, more than 300 environmental chemicals, mostly pesticides, were linked to fatty liver disease. The in vivo studies of DDT showed that it improved steatosis, but it had no effect on NAFLD, obesity, liver damage or diabetes caused by DIO. DDT appeared to contribute to these effects through CAR activation. However, further investigation is required in terms of CAR direct vs. indirect activation and if using higher doses could consequently activate PXR as well. 


\section{REFERENCES}

1. $\quad$ EPA UEPA. About Pesticides. In; 2013.

2. Nebert DW, Gonzalez FJ. P450 genes: structure, evolution, and regulation. Annu Rev Biochem 1987;56:945-993.

3. Nelson DR, Koymans L, Kamataki T, Stegeman JJ, Feyereisen R, Waxman DJ, Waterman MR, et al. P450 superfamily: update on new sequences, gene mapping, accession numbers and nomenclature. Pharmacogenetics 1996;6:142.

4. Wahlang B, Beier JI, Clair HB, Bellis-Jones HJ, Falkner KC, McClain CJ, Cave MC. Toxicant-associated steatohepatitis. Toxicol Pathol 2013;41:343-360.

5. EPA UEPa. Types of Pesticides. In: Pesticides; 2012.

6. Taylor JR, Selhorst JB, Houff SA, Martinez AJ. Chlordecone intoxication in man. I. Clinical observations. Neurology 1978;28:626-630.

7. Adams LA, Lymp JF, St Sauver J, Sanderson SO, Lindor KD, Feldstein A, Angulo $P$. The natural history of nonalcoholic fatty liver disease: A population-based cohort study. Gastroenterology 2005;129:113-121.

8. Cave M, Appana S, Patel M, Falkner KC, McClain CJ, Brock G. Polychlorinated Biphenyls, Lead, and Mercury Are Associated with Liver Disease in American Adults: NHANES 2003-2004. Environmental Health Perspectives 2010;118:1735-1742.

9. Yilmaz Y. Review article: is non-alcoholic fatty liver disease a spectrum, or are steatosis and non-alcoholic steatohepatitis distinct conditions? Alimentary Pharmacology \& Therapeutics 2012;36:815-823.

10. Machado M, Cortez-Pinto H. Non-alcoholic fatty liver disease and insulin resistance. Eur J Gastroenterol Hepatol 2005;17:823-826.

11. Cave M, Falkner KC, Ray M, Joshi-Barve S, Brock G, Khan R, Homme MB, et al. Toxicant-Associated Steatohepatitis In Vinyl Chloride Workers. Hepatology 2010;51:474-481.

12. Alba LM, Lindor K. Non-alcoholic fatty liver disease. Alimentary Pharmacology \& Therapeutics 2003;17:977-986.

13. Yilmaz Y. Review article: is non-alcoholic fatty liver disease a spectrum, or are steatosis and non-alcoholic steatohepatitis distinct conditions? Aliment Pharmacol Ther 2012;36:815-823.

14. Canet MJ, Hardwick RN, Lake AD, Kopplin MJ, Scheffer GL, Klimecki WT, Gandolfi AJ, et al. Altered arsenic disposition in experimental nonalcoholic fatty liver disease. Drug Metab Dispos 2012;40:1817-1824.

15. Aly FZ, Kleiner DE. Update on Fatty Liver Disease and Steatohepatitis. Advances in Anatomic Pathology 2011;18:294-300. 
16. Day CP, James OF. Steatohepatitis: a tale of two "hits"? Gastroenterology 1998;114:842-845.

17. Cave M, Falkner KC, Ray M, Joshi-Barve S, Brock G, Khan R, Bon Homme M, et al. Toxicant-associated steatohepatitis in vinyl chloride workers. Hepatology 2010;51:474-481.

18. Cave M, Falkner KC, Henry L, Costello B, Gregory B, McClain CJ. Serum cytokeratin 18 and cytokine elevations suggest a high prevalence of occupational liver disease in highly exposed elastomer/polymer workers. J Occup Environ Med 2011;53:1128-1133.

19. Cave M, Appana S, Patel M, Falkner KC, McClain CJ, Brock G. Environmental exposure to hepatic steatosis pollutants. Environnement Risques \& Sante 2011;10:362-363.

20. Brautbar N, Williams J, 2nd. Industrial solvents and liver toxicity: risk assessment, risk factors and mechanisms. Int J Hyg Environ Health 2002;205:479-491.

21. Cotrim HP, De Freitas LA, Freitas C, Braga L, Sousa R, Carvalho F, Parana R, et al. Clinical and histopathological features of NASH in workers exposed to chemicals with or without associated metabolic conditions. Liver Int 2004;24:131-135.

22. Cave M, Falkner, K.C., and McClain: Occupational and Environmental Hepatotoxicity. In: Hepatology ZaBs, ed. A Textbook of Liver Disease. Philadelphia, PA: Elsevier Saunders, 2011; 476-492.

23. Konno Y, Negishi M, Kodama S. The roles of nuclear receptors CAR and PXR in hepatic energy metabolism. Drug Metab Pharmacokinet 2008;23:8-13.

24. Lopez-Velazquez JA, Carrillo-Cordova LD, Chavez-Tapia NC, Uribe M, MendezSanchez N. Nuclear receptors in nonalcoholic Fatty liver disease. J Lipids 2012;2012:139875.

25. Feige JN, Gelman L, Michalik L, Desvergne B, Wahli W. From molecular action to physiological outputs: Peroxisome proliferator-activated receptors are nuclear receptors at the crossroads of key cellular functions. Progress in Lipid Research 2006;45:120-159.

26. Schmidt MV, Brune B, von Knethen A. The Nuclear Hormone Receptor PPAR gamma as a Therapeutic Target in Major Diseases. Thescientificworldjournal 2010;10:2181-2197.

27. Maida A, Lamont BJ, Cao X, Drucker DJ. Metformin regulates the incretin receptor axis via a pathway dependent on peroxisome proliferator-activated receptor-alpha in mice. Diabetologia 2011;54:339-349.

28. Hollman DAA, Milona A, van Erpecum KJ, van Mil SWC. Anti-inflammatory and metabolic actions of FXR: Insights into molecular mechanisms. Biochimica Et Biophysica Acta-Molecular and Cell Biology of Lipids 2012;1821:1443-1452.

29. Zivkovic AM, German JB, Sanyal AJ. Comparative review of diets for the metabolic syndrome: implications for nonalcoholic fatty liver disease. Am J Clin Nutr 2007;86:285-300.

30. Silverman JF, Pories WJ, Caro JF. Liver pathology in diabetes mellitus and morbid obesity. Clinical, pathological, and biochemical considerations. Pathol Annu 1989;24 Pt 1:275-302. 
31. EPA UEPA. Pesticide News Story: EPA Releases Report Containing Latest Estimates of Pesticide Use in the United States. In; 2011.

32. Tolman KG, and Sirrine, R. Occupational hepatotoxicity. Clin Liver Dis 1998: 563-589.

33. Cave MC, Beier JI, Wheeler B, Falkner KC, Bellis-Jones HJ, Clair HB, McClain CJ. Occupational Vinyl Chloride Exposures Are Associated With Significant Changes To The Plasma Metabolome: Implications For Toxicant Associated Steatohepatitis. Hepatology 2012;56:882A-883A.

34. Cave MC, Falkner KC, Costello B, McClain CJ. Serum Cytokeratin 18 and Cytokine Elevations Suggest a High Prevalence of Occupational Liver Disease in Elastomer/Polymer Workers Highly Exposed to Acrylonitrile, Butadiene and Styrene. Gastroenterology 2011;140:S975-S975.

35. CAS CAS. CAS REGISTRY - The gold standard for chemical substance information. In; 2014.

36. Kleiner DE, Brunt EM. Nonalcoholic fatty liver disease: pathologic patterns and biopsy evaluation in clinical research. Semin Liver Dis 2012;32:3-13.

37. NCHS. NCHS (National Center for Health Statistics) NHANES 2003-2004 Public General Release File Documentation. In; 2005.

38. Cave M, Appana S, Patel M, Falkner KC, McClain CJ, Brock G. Polychlorinated biphenyls, lead, and mercury are associated with liver disease in American adults: NHANES 2003-2004. Environ Health Perspect 2010;118:1735-1742.

39. Prati D, Taioli E, Zanella A, Della Torre E, Butelli S, Del Vecchio E, Vianello L, et al. Updated definitions of healthy ranges for serum alanine aminotransferase levels. Ann Intern Med 2002;137:1-10.

40. EPA UEPA. EPA's ToxCast ${ }^{\mathrm{TM}}$ Research Program. In: Pesticides: Science and Policy.

41. (EPA) UEPA. Computational Toxicology Research Program: ToxRefDB. In.

42. Matthew T. Martin RJ, Ann M. Richard, Keith A. Houck, David J. Dix. ToxRefDB: Linking Regulatory Toxicological Information on Environmental Chemicals with High-Throughput Screening (HTS) and Genomic Data. In: International Science Forum on Computational Toxicology; 2007.

43. Baskar DS. Environmental Studies for Undergraduate Courses: Unicorn Books Pvt Ltd, 2008: 363.

44. NTP. New CEBS File Assists Database Collaboration. In.

45. Waters M, Stasiewicz S, Merrick BA, Tomer K, Bushel P, Paules R, Stegman N, et al. CEBS--Chemical Effects in Biological Systems: a public data repository integrating study design and toxicity data with microarray and proteomics data. Nucleic Acids Res 2008;36:D892-900.

46. Sciences NIoH. Chemical Effects in Biological Systems (CEBS). In; 2012.

47. National Toxicology P. Toxicology and carcinogenesis studies of 2,3',4,4',5pentachlorobiphenyl (PCB 118) (CAS No. 31508-00-6) in female harlan Sprague-Dawley rats (gavage studies). Natl Toxicol Program Tech Rep Ser 2010:1-174.

48. Cecil S. Request for time critical removal action, Black Leaf Chemical, Louisville, Jefferson County, Kentucky: Superfund branch, Kentucky Division of Waste Management; 2011. 
49. EPA USEPA. POLLUTION/SITUATION REPORT; Black Leaf Chemical - Removal Polrep; 2013.

50. Reigart JRRaJR: Fungicides. In: RECOGNITION AND MANAGEMENT OF PESTICIDE POISONINGS. 6th ed: The National Association of State Departments of Agriculture Research Foundation (NASDARF), 2013; 143-116-

51. Hester SD, Wolf DC, Nesnow S, Thai SF. Transcriptional profiles in liver from rats treated with tumorigenic and non-tumorigenic triazole conazole fungicides: Propiconazole, triadimefon, and myclobutanil. Toxicol Pathol 2006;34:879-894.

52. Peffer RC, Moggs JG, Pastoor T, Currie RA, Wright J, Milburn G, Waechter F, et al. Mouse liver effects of cyproconazole, a triazole fungicide: role of the constitutive androstane receptor. Toxicol Sci 2007;99:315-325.

53. EPA UEPAOoPP. RED Fact Sheet: Dazomet 2008

54. Authority CRSNR. NRA Report on the Special Review of Metham Sodium, Dazomet and Methylisothiocyanate (MITC); 1997.

55. EPA USEPA. Hexaconazole (ANVIL 25 SC; ANVIL 25EC/OL» in or on Imported Bananas; 1999.

56. Reschly EJ, Krasowski MD. Evolution and function of the NR1I nuclear hormone receptor subfamily (VDR, PXR, and CAR) with respect to metabolism of xenobiotics and endogenous compounds. Curr Drug Metab 2006;7:349-365.

57. EPA UEPA. EPA's ToxCast ${ }^{\mathrm{TM}}$ Research Program. In; 2012.

58. Boyd EM, Taylor FI. The acute oral toxicity of chlordane in albino rats fed for 28 days from weaning on a protein-deficient diet. IMS Ind Med Surg 1969;38:434-441.

59. Wahlang B, Falkner KC, Gregory B, Ansert D, Young D, Conklin DJ, Bhatnagar A, et al. Polychlorinated biphenyl 153 is a diet-dependent obesogen that worsens nonalcoholic fatty liver disease in male C57BL6/J mice. J Nutr Biochem 2013;24:1587-1595.

60. WHO WHO. DDT IN INDOOR RESIDUAL SPRAYING: HUMAN HEALTH ASPECTS. 2011.

61. Kiyosawa N, Kwekel JC, Burgoon LD, Dere E, Williams KJ, Tashiro C, Chittim B, et al. Species-specific regulation of PXR/CAR/ER-target genes in the mouse and rat liver elicited by o, p'-DDT. BMC Genomics 2008;9:487.

62. Kiyosawa N, Kwekel JC, Burgoon LD, Williams KJ, Tashiro C, Chittim B, Zacharewski TR. o,p'-DDT elicits PXR/CAR-, not ER-, mediated responses in the immature ovariectomized rat liver. Toxicol Sci 2008;101:350-363.

63. Wyde ME, Bartolucci E, Ueda A, Zhang H, Yan B, Negishi M, You L. The environmental pollutant 1,1-dichloro-2,2-bis (p-chlorophenyl)ethylene induces rat hepatic cytochrome $\mathrm{P} 4502 \mathrm{~B}$ and $3 \mathrm{~A}$ expression through the constitutive androstane receptor and pregnane $\mathrm{X}$ receptor. Mol Pharmacol 2003;64:474-481.

64. DeCarvalho JP. DDT. In: Toxipedia; 2013.

65. United States. Environmental Protection Agency., United States. Congress. House. Committee on Appropriations. DDT : a review of scientific and 
economic aspects of the decision to ban its use as a pesticide : prepared for Committee on Appropriations, U.S. House of Representatives. Washington Springfield, Va.: U.S. Environmental Protection Agency ;

for sale by National Technical Information Service, 1975: $300 \mathrm{p}$.

66. Turusov V, Rakitsky V, Tomatis L. Dichlorodiphenyltrichloroethane (DDT): ubiquity, persistence, and risks. Environ Health Perspect 2002;110:125-128.

67. IARC. Occupational exposures in insecticide application, and some pesticides. IARC Working Group on the Evaluation of Carcinogenic Risks to Humans. Lyon, 16-23 October 1990. IARC Monogr Eval Carcinog Risks Hum 1991;53:5586.

68. McGlynn KA, Abnet CC, Zhang MD, Sun XD, Fan JH, O'Brien TR, Wei WQ, et al. Serum concentrations of 1,1,1-Trichloro-2,2-bis (p-chlorophenyl)ethane (DDT) and 1,1-Dichloro-2,2-bis (p-chlorophenyl)ethylene (DDE) and risk of primary liver cancer. Journal of the National Cancer Institute 2006;98:10051010.

69. Hunter DJ, Hankinson SE, Laden F, Colditz GA, Manson JE, Willett WC, Speizer $\mathrm{FE}$, et al. Plasma organochlorine levels and the risk of breast cancer. N Engl J Med 1997;337:1253-1258.

70. Longnecker MP, Rogan WJ, Lucier G. The human health effects of DDT (dichlorodiphenyltrichloroethane) and PCBS (polychlorinated biphenyls) and an overview of organochlorines in public health. Annu Rev Public Health 1997;18:211-244.

71. United States. Agency for Toxic Substances and Disease Registry. Toxicological profile for DDT, DDE, and DDD. In. Atlanta, Ga.: U.S. Dept. of Health and Human Services, Public Health Service, Agency for Toxic Substances and Disease Registry,; 2002. p. 1 online resource ( 497 p.).

72. Matthews DR, Hosker JP, Rudenski AS, Naylor BA, Treacher DF, Turner RC. Homeostasis model assessment: insulin resistance and beta-cell function from fasting plasma glucose and insulin concentrations in man. Diabetologia 1985;28:412-419.

73. Livak KJ, Schmittgen TD. Analysis of relative gene expression data using realtime quantitative PCR and the 2(-Delta Delta C(T)) Method. Methods 2001;25:402-408.

74. Rakhshandehroo M, Knoch B, Muller M, Kersten S. Peroxisome proliferatoractivated receptor alpha target genes. PPAR Res 2010;2010.

75. Xu S, Jay A, Brunaldi K, Huang N, Hamilton JA. CD36 enhances fatty acid uptake by increasing the rate of intracellular esterification but not transport across the plasma membrane. Biochemistry 2013;52:7254-7261.

76. Dong B, Saha PK, Huang W, Chen W, Abu-Elheiga LA, Wakil SJ, Stevens RD, et al. Activation of nuclear receptor CAR ameliorates diabetes and fatty liver disease. Proc Natl Acad Sci U S A 2009;106:18831-18836.

77. Ouchi N, Kihara S, Funahashi T, Nakamura T, Nishida M, Kumada M, Okamoto $\mathrm{Y}$, et al. Reciprocal association of C-reactive protein with adiponectin in blood stream and adipose tissue. Circulation 2003;107:671-674. 
78. Jamaluddin MS, Weakley SM, Yao Q, Chen C. Resistin: functional roles and therapeutic considerations for cardiovascular disease. Br J Pharmacol 2012;165:622-632.

79. Furuhashi M, Ura N, Nakata T, Shimamoto K. Insulin sensitivity and lipid metabolism in human CD36 deficiency. Diabetes Care 2003;26:471-474.

80. Calvo D, Gomez-Coronado D, Suarez Y, Lasuncion MA, Vega MA. Human CD36 is a high affinity receptor for the native lipoproteins HDL, LDL, and VLDL. Journal of Lipid Research 1998;39:777-788.

81. Endemann G, Stanton LW, Madden KS, Bryant CM, White RT, Protter AA. Cd36 Is a Receptor for Oxidized Low-Density-Lipoprotein. Journal of Biological Chemistry 1993;268:11811-11816.

82. Kachaylo EM, Pustylnyak VO, Lyakhovich VV, Gulyaeva LF. Constitutive androstane receptor (CAR) is a xenosensor and target for therapy. Biochemistry-Moscow 2011;76:1087-1097.

83. Mutoh S, Sobhany M, Moore R, Perera L, Pedersen L, Sueyoshi T, Negishi M. Phenobarbital indirectly activates the constitutive active androstane receptor (CAR) by inhibition of epidermal growth factor receptor signaling. Sci Signal 2013;6:ra31.

84. Gao J, He JH, Zhai YG, Wada TR, Xie W. The Constitutive Androstane Receptor Is an Anti-obesity Nuclear Receptor That Improves Insulin Sensitivity. Journal of Biological Chemistry 2009;284:25984-25992.

85. Koves TR, Ussher JR, Noland RC, Slentz D, Mosedale M, Ilkayeva O, Bain J, et al. Mitochondrial overload and incomplete fatty acid oxidation contribute to skeletal muscle insulin resistance. Cell Metab 2008;7:45-56. 


\section{APPENDICES APPENDIX 1}

Adjusted* Odds Ratios $(95 \% \mathrm{Cl}$ ) for ALT Elevation by Exposure Quartile (With Median Concentration Levels and Number of Cases/Total Number) for Pollutant Subclasses Lead, Cadmium, and Mercury and Organochlorine Pesticides in Adult NHANES 2003-2004.

\begin{tabular}{|c|c|c|c|c|c|c|c|c|c|}
\hline \multirow{2}{*}{ \# } & \multirow{2}{*}{ Pollutant } & \multirow{2}{*}{$\begin{array}{l}\text { Detection } \\
\text { Rate (\%) }\end{array}$} & \multirow{2}{*}{$\begin{array}{c}\text { Not } \\
\text { Detectable }\end{array}$} & \multicolumn{4}{|c|}{ Detectable } & \multirow{2}{*}{$P_{\text {trend }}$} & \multirow{2}{*}{$\mathbf{P}_{\text {trend-adj }}$} \\
\hline & & & & $1^{\text {st }}$ & $2^{\text {nd }}$ & $3^{r d}$ & $4^{\text {th }}$ & & \\
\hline \multirow[t]{3}{*}{1.} & Dieldrin & 88.5 & -- & $3.90^{\mathrm{a}}$ & 5.90 & 8.20 & 14.15 & 0.007 & 0.027 \\
\hline & Lipid Adj (ng/g) & & $13 / 62$ & $38 / 129^{b}$ & $38 / 119$ & $53 / 141$ & $67 / 155$ & & \\
\hline & & & Referent & $1.6(0.7-3.5)^{c}$ & $1.8(0.9-3.6)$ & $2.2(1.1-4.4)$ & $3.1(1.3-7.2)$ & & \\
\hline \multirow[t]{3}{*}{2.} & Heptachlor & 61.7 & -- & 3.60 & 5.60 & 8.90 & 16.70 & 0.001 & 0.009 \\
\hline & Epoxide & & $56 / 214$ & $29 / 82$ & $35 / 112$ & $44 / 106$ & $48 / 97$ & & \\
\hline & Lipid Adj (ng/g) & & Referent & $1.4(0.8-2.4)$ & $1.3(0.7-2.2)$ & $1.9(1.1-3.2)$ & $2.6(1.3-5.0)$ & & \\
\hline \multirow[t]{3}{*}{3.} & Trans-nonachlor & 93.9 & -- & 5.90 & 12.85 & 27.50 & 57.50 & 0.050 & 0.093 \\
\hline & Lipid Adj (ng/g) & & $11 / 37$ & $35 / 139$ & $54 / 138$ & $54 / 137$ & $54 / 153$ & & \\
\hline & & & Referent & $0.7(0.4-1.3)$ & $1.6(0.8-3.2)$ & $1.7(0.6-4.6)$ & $1.6(0.6-3.8)$ & & \\
\hline \multirow[t]{3}{*}{4.} & & 75.4 & -- & 4.30 & 8.80 & 19.10 & 52.40 & 0.082 & 0.093 \\
\hline & $\begin{array}{l}\text { hexachlorocyclo- } \\
\text { hexane }\end{array}$ & & $36 / 146$ & $33 / 97$ & $56 / 133$ & $43 / 117$ & $43 / 116$ & & \\
\hline & Lipid Adj (ng/g) & & Referent & $1.6(1.0-2.8)$ & $2.3(1.4-3.8)$ & $1.8(1.0-3.4)$ & $1.7(0.9-3.5)$ & & \\
\hline \multirow[t]{3}{*}{5.} & Hexachloro- & 99.9 & & 9.90 & 13.75 & 17.60 & 24.60 & 0.075 & 0.093 \\
\hline & benzene & & & $44 / 148$ & $47 / 142$ & $60 / 167$ & $59 / 150$ & & \\
\hline & Lipid Adj (ng/g) & & & Referent & $1.1(0.8-1.6)$ & $1.2(0.9-1.6)$ & & & \\
\hline \multirow[t]{3}{*}{6.} & Oxychlordane & 83.8 & -- & 5.00 & 10.50 & 19.30 & 35.50 & 0.053 & 0.093 \\
\hline & Lipid Adj (ng/g) & & $25 / 106$ & $40 / 117$ & $42 / 123$ & $61 / 142$ & $44 / 125$ & & \\
\hline & & & Referent & $1.8(0.9-3.7)$ & $2.1(0.8-5.7)$ & $3.5(1.4-8.4)$ & $2.7(0.9-8.2)$ & & \\
\hline \multirow[t]{3}{*}{7.} & $p, p^{\prime}-D D E$ & 99.7 & -- & 82.40 & 183.00 & 464.00 & 1535.0 & 0.062 & 0.093 \\
\hline & Lipid Adj (ng/g) & & $0 / 1$ & $43 / 155$ & $52 / 153$ & $57 / 148$ & $57 / 149$ & & \\
\hline & & & & Referent & $1.4(0.8-2.4)$ & $1.7(1.0-2.8)$ & $1.7(0.9-2.9)$ & & \\
\hline \multirow[t]{3}{*}{8.} & $p, p^{\prime}-D D T$ & 79.0 & -- & 3.50 & 5.10 & 7.70 & 19.30 & 0.095 & 0.095 \\
\hline & Lipid Adj (ng/g) & & $35 / 135$ & $35 / 112$ & $42 / 111$ & $54 / 121$ & $42 / 126$ & & \\
\hline & & & Referent & $1.3(0.7-2.4)$ & $1.7(0.8-3.8)$ & $2.2(1.5-3.3)$ & $1.2(0.7-1.9)$ & & \\
\hline
\end{tabular}

* ORs were adjusted for age, sex, race, poverty income ratio, HOMA-IR, and BMI.

${ }^{a}$ Median concentration levels.

${ }^{\mathrm{b}}$ Number of cases / total number.

${ }^{c}$ Adjusted odds ratios with $95 \%$ confidence intervals.

${ }^{\dagger}$ Additionally adjusted for multiple comparisons.

$1^{\text {st }}$ quartile: $\leq 25^{\text {th }}$ percentile, $2^{\text {td }}$ quartile: $25^{\text {th }}-\leq 50^{\text {th }}$ percentile, $3^{\text {rd }}$ quartile: $50^{\text {th }}-\leq$ $75^{\text {th }}$ percentile, $4^{\text {th }}$ quartile: $>75^{\text {th }}$ percentile.

Abbreviations: $\mathrm{Cl}$; confidence interval 


\section{APPENDIX 2}

Pesticides associated with fatty liver disease in ToxRefDB.

\begin{tabular}{|c|c|c|c|}
\hline \# & Chemical Name & $\begin{array}{l}\text { Study Design } \\
\text { and species }\end{array}$ & $\begin{array}{l}\text { LEL } \\
\text { (mg/kg/day) }\end{array}$ \\
\hline \multicolumn{4}{|c|}{ Fungicides: } \\
\hline 1. & Bromuconazole & $\begin{array}{l}\text { Mouse- } \\
\text { Subchronic }\end{array}$ & 68.1 \\
\hline 2. & Cyproconazole & $\begin{array}{l}\text { Rat-Chronic } \\
\text { Rat-MGR }^{*}\end{array}$ & $\begin{array}{l}8.29 \\
15.6 \\
\end{array}$ \\
\hline 3. & Dazomet & $\begin{array}{l}\text { Rat-Chronic } \\
\text { Mouse-Chronic } \\
\text { Rat-MGR* }\end{array}$ & $\begin{array}{l}69.9 \\
2.78 \\
3.71 \\
\end{array}$ \\
\hline 4. & $\begin{array}{l}\text { Diethyl 4,4'-o-phenylenebis (3- } \\
\text { thioallophanate) }\end{array}$ & Mouse-Chronic & 300 \\
\hline 5. & Difenoconazole & Mouse-Chronic & 819 \\
\hline 6. & Dimethomorph & Rat-Subchronic & 14.2 \\
\hline 7. & Famoxadone & Mouse-Chronic & 274 \\
\hline 8. & Fenarimol & $\begin{array}{l}\text { Rat-Chronic } \\
\text { Mouse-Chronic }\end{array}$ & $\begin{array}{l}14.6 \\
86\end{array}$ \\
\hline 9. & Fluazinam & $\begin{array}{l}\text { Rat-Chronic } \\
\text { Rat-MGR* }\end{array}$ & $\begin{array}{l}40 \\
9.7\end{array}$ \\
\hline 10. & Flusilazole & $\begin{array}{l}\text { Rat-Subchronic } \\
\text { Rat-Chronic }\end{array}$ & $\begin{array}{l}55 \\
13\end{array}$ \\
\hline 11. & Hexaconazole & $\begin{array}{l}\text { Rat-Subchronic } \\
\text { Rat-Chronic } \\
\text { Rat-MGR }^{*}\end{array}$ & $\begin{array}{l}25 \\
4.7 \\
5\end{array}$ \\
\hline 12. & Iprodione & Mouse-Chronic & 604 \\
\hline 13. & Propiconazole & Rat-Chronic & 96.4 \\
\hline 14. & Metalaxyl & Rat-MGR* & 62.5 \\
\hline 15. & Oxytetracycline hydrochloride & Rat-Chronic & 1250 \\
\hline 16. & Paclobutrazol & $\begin{array}{l}\text { Mouse-Chronic } \\
\text { Rat-MGR* }^{*}\end{array}$ & $\begin{array}{l}113 \\
62.5 \\
\end{array}$ \\
\hline 17. & $\begin{array}{l}\text { Propanoic acid, 2-(2,4-dichlorophenoxy)-, } \\
\text { (R)- }\end{array}$ & Rat-Subchronic & 144 \\
\hline 18. & Triadimefon & $\begin{array}{l}\text { Rat-Chronic } \\
\text { Mouse-Chronic }\end{array}$ & $\begin{array}{l}114 \\
550\end{array}$ \\
\hline 19. & Triadimenol & Rat-Subchronic & 39.6 \\
\hline 20. & Trifloxystrobin & Mouse-Chronic & 274 \\
\hline 21. & Triflumizole & Mouse-Chronic & 67.4 \\
\hline & Vinclozolin & $\begin{array}{l}\text { Mouse-Chronic } \\
\text { Rat-MGR* }\end{array}$ & $\begin{array}{l}1230 \\
290\end{array}$ \\
\hline
\end{tabular}




\begin{tabular}{llll}
\hline$\#$ & Chemical Name & $\begin{array}{l}\text { Study Design and } \\
\text { species }\end{array}$ & $\begin{array}{l}\text { LEL } \\
\text { (mg/kg/day) }\end{array}$ \\
\hline Herbicides: & Rat-Subchronic & 100 \\
\hline 23. & Bensulide & Rat-Chronic & 13 \\
\hline 24. & Butafenacil & Rat Chronic & 309 \\
\hline 25. & Chlorsulfuron & Rat-Subchronic & 1900 \\
\hline 26. & Ethofumesate & Rat-Subchronic & 216 \\
\hline & & Rat-Chronic & 130 \\
27. & Fluthiacet-methyl & Mouse-Chronic & 37 \\
& & Rat-MGR* & 31.8 \\
\hline 28. & Mesosulfuron-methyl & Mouse-Chronic & 1360 \\
\hline 29. & Oxadiazon & Rat-Chronic & 50.9 \\
\hline 30. & Pyrasulfotole metabolite (SXX & Rat-MGR* & 9.48 \\
\hline 31. & Rimsulfuron & Rat-Chronic & 121 \\
\hline 32. & Sethoxydim & Mouse-Chronic & 41.2 \\
\hline 33. & Sulfentrazone & Rat Subchronic & 199 \\
\hline 34. & Tepraloxydim & Rat-Subchronic & 383 \\
\hline 35. & Thiazopyr & Rat-Subchronic & 201 \\
\hline Insecticides: & & \\
\hline 36. & Buprofezin & Rat-Subchronic \\
\hline 37. & Chlorpyrifos-methyl & 316 \\
\hline 38. & d-cis,trans-Allethrin & Mouse-Chronic \\
\hline 39. & Fipronil & Mouse-Chronic \\
\hline 40. & Tetramethrin & Rat-Subchronic & 31.5 \\
\hline 41. & Thiacloprid & Rat-Subchronic \\
\hline Miticide: & Mouse-Chronic \\
\hline 42. & Acequinocyl & 19.9 \\
\hline & & 57.9 \\
\hline
\end{tabular}

Chemicals are arranged according in alphabetic order in each class and their LELs are provided according to the screened ToxRefDB studies.

*MGR: Multigeneration Reproductive 


\section{APPENDIX 3}

Solvents, plasticizers, monomers, and Chemical Intermediates associated with fatty liver disease in CEBS.

\begin{tabular}{|c|c|c|}
\hline \# Chemical Name & $\begin{array}{l}\text { Study Design and } \\
\text { species }\end{array}$ & $\begin{array}{l}\text { LEL } \\
(\mathrm{mg} / \mathrm{kg})\end{array}$ \\
\hline 1. 2,2-Bis(Bromomethyl)-1,3 propanediol & Rat-Chronic & 25,000 \\
\hline 2. 4-Vinyl-1-cyclohexene diepoxide & Rat-Chronic & 50 \\
\hline 3. 4,4'-Thiobis(6-tert-butyl-m-cresol) & Mouse-Chronic & 250 \\
\hline 4. Alpha-Methylstyrene & Mouse-Chronic & 300 \\
\hline 5. Dibutyl phthalate & Rat-Short term & 600 \\
\hline 6. Divinylbenzene & Mouse-Chronic & 10 \\
\hline 7. Glycidol & Mouse- Short term & 100 \\
\hline 8. Isoprene & Rat-Chronic & 220 \\
\hline 9. Resorcinol & Rat-Chronic & 50 \\
\hline 10. Sodium selenite & Rat-Short Term & 4 \\
\hline 11. Tetrabromobisphenol A & Mouse-Short Term & 100 \\
\hline 12. Tetrafluoroethylene & Rat-Chronic & 156 \\
\hline 13. Tricresyl phosphate & Rat-Chronic & 75 \\
\hline 14. Trimethylolpropane triacrylate & Rat-Chronic & 0.3 \\
\hline 15. Vinyl toluene & $\begin{array}{l}\text { Rat-Chronic } \\
\text { Mouse-Chronic }\end{array}$ & $\begin{array}{l}100 \\
25\end{array}$ \\
\hline 16. 1-Amino-2,4-dibromoanthraquinone & Rat-Chronic & 20,000 \\
\hline $\begin{array}{l}\text { 17. 4,4'-Diamino-2,2'-stilbenedisulfonic acid, } \\
\text { disodium salt }\end{array}$ & Mouse-Chronic & 6250 \\
\hline 18. p-Nitrobenzoic acid & Mouse-Chronic & 1250 \\
\hline 19. p-Nitrotoluene & Mouse & 1250 \\
\hline 20. 2-Methylimidazole & Rat-Chronic & 1000 \\
\hline 21. Methyl isobutyl ketone & Mouse-Chronic & 900 \\
\hline 22. Toluene & $\begin{array}{l}\text { Rat-Chronic } \\
\text { Mouse-Chronic }\end{array}$ & 600 \\
\hline 23. Barium chloride dehydrate & Rat-Chronic & 500 \\
\hline 24. Styrene-acrylonitrile trimer & Rat-Short term & 250 \\
\hline 25. Decalin & Mouse-Chronic & 100 \\
\hline 26. 3,3'-Dimethoxybenzidine dihydrochloride & Rat-Chronic & 80 \\
\hline 27. bis(2-Chloroethoxy)methane & Rat-Chronic & 75 \\
\hline 28. 1-Bromopropane & Mouse-Chronic & 62.5 \\
\hline 29. Tribromomethane & Mouse-Chronic & 50 \\
\hline 30. Sodium dichromate dihydrate (VI) & Rat-Chronic & 14.3 \\
\hline
\end{tabular}


$\mathrm{mg} / \mathrm{L}$

31. 1,2-Dihydro-2,2,4-trimethylquinoline

Mouse-Short term

3.6 (monomer)

Chemicals are arranged in alphabetic order and their LELs are provided according to the screened CEBS studies. 


\section{APPENDIX 4}

Miscellaneous chemicals associated with fatty liver disease in CEBS.

\begin{tabular}{rlll}
\hline$\#$ & Chemical Name & $\begin{array}{l}\text { Study Design and } \\
\text { species }\end{array}$ & LEL \\
\hline 1. & Polysorbate 80 & Rat-Chronic & $25,000 \mathrm{mg} / \mathrm{kg}$ \\
\hline 2. & T-Butylhydroquinone & Mouse-Chronic & $1,250 \mathrm{mg} / \mathrm{kg}$ \\
\hline 3. & Benzophenone & Rat-Chronic & $312 \mathrm{mg} / \mathrm{kg}$ \\
\hline 4. & Cumene hydroperoxide & Rat-Short term & $100 \mathrm{mg} / \mathrm{kg}$ \\
\hline 5. & Isobutyl nitrite & Mouse-Chronic & $37.5 \mathrm{mg} / \mathrm{kg}$ \\
\hline 6. & N,N-Dimethyl-p-toluidine & Rat-Chronic & $6 \mathrm{mg} / \mathrm{kg}$ \\
\hline 7. & Sodium azide & Rat-Chronic & $5 \mathrm{mg} / \mathrm{kg}$ \\
\hline 8. & Tetranitromethane & Rat-Chronic & $2 \mathrm{mg} / \mathrm{kg}$ \\
\hline 9. & Vanadium oxide & Rat-Chronic & $1 \mathrm{mg} / \mathrm{M} 3$ \\
\hline 10. Nickel (II) oxide & Mouse-Chronic & $0.63 \mathrm{mg} / \mathrm{m3}$ \\
\hline 11. Nickel sulfate hexahydrate & Rat-Chronic & $0.25 \mathrm{mg} / \mathrm{m3}$ \\
\hline 12. Indium phosphide & Rat-Chronic & $0.03 \mathrm{mg} / \mathrm{m3}$ \\
\hline 13. Gallium arsenide & Rat-Chronic & $0.01 \mathrm{mg} / \mathrm{M3}$ \\
\hline 14. $\begin{array}{l}\text { 3,3'-Dimethylbenzidine } \\
\text { dihydrochloride }\end{array}$ & Rat-Chronic & $0.003^{* *}$ \\
\hline
\end{tabular}

Chemicals are arranged in alphabetic order and their LELs are provided according to the screened CEBS studies.

** Units were not provided in the CEBS search. 


\section{APPENDIX 5}

Pesticides associated with fatty liver disease in CEBS.

\begin{tabular}{|c|c|c|c|}
\hline \# & Chemical Name & $\begin{array}{l}\text { Study Design and } \\
\text { species }\end{array}$ & $\begin{array}{l}\text { LEL } \\
(\mathrm{mg} / \mathrm{kg})\end{array}$ \\
\hline 1. & 1,2-Dibromo-2,4-dicyanobutane & Rat-Chronic & 2 \\
\hline 2. & 1,2,3-Trichloropropane & Mouse-Chronic & 6 \\
\hline 3. & 1,2,3-Trichloropropane & Rat-Chronic & 3 \\
\hline 4. & 3,3',4,4'-Tetrachloroazobenzene & Rat-Chronic & 10 \\
\hline 5. & Beta-Picoline & Rat-Chronic & $312.5 \mathrm{mg} / \mathrm{L}$ \\
\hline 6. & Formamide & Rat-Chronic & 20 \\
\hline 7. & Fumonisin B1 & Mouse-Chronic & 80 \\
\hline 8. & Hexachloroethane & Rat-Chronic & 10 \\
\hline 9. & Monochloroacetic acid & Rat-Chronic & 10 \\
\hline 10. & Naphthalene & Rat-Chronic & 10 \\
\hline 11. & p,p'-Dichlorodiphenyl sulfone & Mouse-Chronic & 30 \\
\hline 12. & Triethanolamine & Mouse-Chronic & 630 \\
\hline
\end{tabular}

Pesticides are arranged in alphabetic order and their LELs are provided according to the screened CEBS studies. 


\section{APPENDIX 6}

Fragrances, cosmetics and essential oils associated with fatty liver disease in CEBS.

\begin{tabular}{llll}
\hline$\#$ & Chemical Name & $\begin{array}{l}\text { Study Design and } \\
\text { species }\end{array}$ & $\begin{array}{l}\text { LEL } \\
(\mathbf{m g} / \mathbf{k g})\end{array}$ \\
\hline 1. & 3,4-Dihydrocoumarin & Mouse-Chronic & 200 \\
\hline 2. & Beta-Myrcene & Mouse-Chronic & 250 \\
\hline 3. & Dipropylene glycol & Rat-Chronic & 25,000 \\
\hline 4. & Estragole & Mouse-Short term & 37.5 \\
\hline 5. & Hydroquinone & Rat-Chronic & 25 \\
\hline 6. & Isoeugenol & Rat-Chronic & 75 \\
\hline 7. & Methyl trans-styryl ketone & Mouse-Chronic & 10 \\
\hline 8. & Methyleugenol & Mouse-Chronic & 10 \\
\hline 9. & Tris(2-Chloroethyl) phosphate & Rat-Short term & 150 \\
\hline & & Rat-Chronic & 44 \\
\hline
\end{tabular}

Chemicals are arranged in alphabetic order and their LELs are provided according to the screened CEBS studies. 


\section{APPENDIX 7}

Paints, polishes, dyes and food additives associated with fatty liver disease in CEBS.

\begin{tabular}{llll}
\hline \# & Chemical Name & $\begin{array}{l}\text { Study Design and } \\
\text { species }\end{array}$ & $\begin{array}{l}\mathrm{LEL} \\
(\mathbf{m g} / \mathbf{k g})\end{array}$ \\
\hline 1 2-Butoxyethanol & Rat-Chronic & 31.2 \\
\hline 2 & $2,4-$-Diaminophenol dihydrochloride & Mouse-Chronic & 0.038 \\
\hline 3 Benzyl acetate & Rat-Chronic & 3,000 \\
\hline 4 C.I. Acid red 114 & Rat-Chronic & 0.007 \\
\hline 5 C.I. Direct blue 15 & Rat-Chronic & $0.125^{\star *}$ \\
\hline 6 C.I. Direct blue 218 & $\begin{array}{l}\text { Rat -Chronic } \\
\text { Mouse-Chronic }\end{array}$ & 1,000 \\
\hline 7 HC yellow 4 & Rat-Chronic & 25,000 \\
\hline 8 Malachite green & Rat-Chronic & 600 \\
\hline 9 Pyrogallol & Rat-Chronic & 5 \\
\hline
\end{tabular}

Chemicals are arranged in alphabetic order and their LELs are provided according to the screened CEBS studies.

** Units were not provided in the CEBS search. 


\section{APPENDIX 8}

PCBs and dioxin-like compounds associated with fatty liver disease in CEBS.

\begin{tabular}{llll}
\hline$\#$ & Chemical Name & $\begin{array}{l}\text { Study } \\
\text { Design and } \\
\text { species }\end{array}$ & $\begin{array}{l}\text { LEL } \\
(\mathbf{m g} / \mathbf{k g})\end{array}$ \\
\hline 1. & $\begin{array}{l}2,3,7,8-\text {-Tetrachlorodibenzo-p-dioxin } \\
(\text { TCDD })\end{array}$ & Rat-Chronic & 0.01 \\
\hline 2. & Dioxin mixture & Rat-Chronic & 10 \\
\hline 3. & PCB 118 & Rat-Chronic & 0.1 \\
\hline 4. & PCB 126 & Rat-Chronic & 0.00001 \\
\hline 5. & PCB 153 & Rat-Chronic & 0.01 \\
\hline 6. & Pentachlorodibenzofuran (PECDF) & Rat-Chronic & 0.000006 \\
\hline
\end{tabular}

Chemicals are arranged in alphabetic order and their LELs are provided according to the screened CEBS studies. 
APPENDIX 9

Pesticides associated Activate hPXR in NCGC-PXR ToxCastDB.

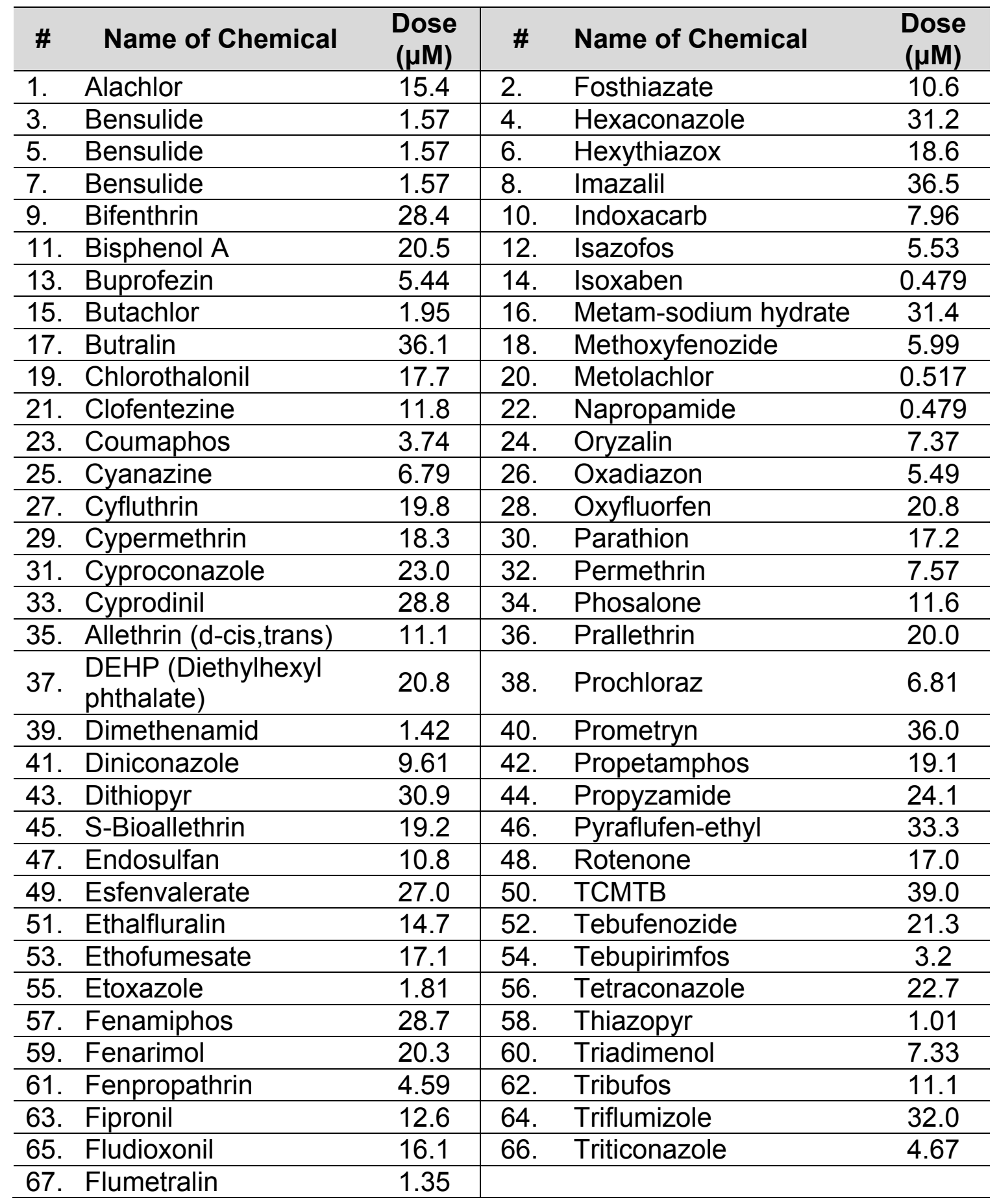

Chemicals are arranged in alphabetic order. 
Pesticides associated Activate hPXR in ATG_PXR_TRANS ToxCastDB.

\begin{tabular}{|c|c|c|c|c|c|}
\hline \# & Name of Chemical & $\begin{array}{l}\text { Dose } \\
(\mu \mathrm{M})\end{array}$ & \# & Name of Chemical & $\begin{array}{l}\text { Dose } \\
(\mu \mathrm{M})\end{array}$ \\
\hline 1. & Alachlor & 5.7 & 2. & Fluthiacet-methyl & 53.0 \\
\hline 3. & Ametryn & 34.0 & 4. & Flutolanil & 34.0 \\
\hline 5. & Azoxystrobin & 4.3 & 6. & Hexythiazox & 8.5 \\
\hline 7. & Benfluralin & 32.0 & 8. & Imazapic & 51.0 \\
\hline 9. & Bensulide & 1.4 & 10. & Imidacloprid & 72.0 \\
\hline 11. & Bensulide & 0.56 & 12. & Indoxacarb & 7.3 \\
\hline 13. & Bensulide & 0.91 & 14. & Iprodione & 11.0 \\
\hline 15. & Bentazone & 47.0 & 16. & Isazofos & 4.5 \\
\hline 17. & Bifenazate & 11.0 & 18. & Isoxaben & 1.0 \\
\hline 19. & Bifenthrin & 4.1 & 20. & Lactofen & 26.0 \\
\hline 21. & Bisphenol A & 14.0 & 22. & Lindane & 22.0 \\
\hline 23. & Buprofezin & 3.8 & 24. & Linuron & 40.0 \\
\hline 25. & Butachlor & 1.1 & 26. & Malathion & 31.0 \\
\hline 27. & Butralin & 7.7 & 28. & Metalaxyl & 14.0 \\
\hline 29. & Carfentrazone-ethyl & 43.0 & 30. & Methoxyfenozide & 2.4 \\
\hline 31. & Chlorothalonil & 0.22 & 32. & Metolachlor & 6.6 \\
\hline 33. & Chlorpropham & 45.0 & 34. & MGK & 18.0 \\
\hline 35. & Cinmethylin & 6.6 & 36. & Molinate & 62.0 \\
\hline 37. & Clomazone & 35.0 & 38. & Napropamide & 1.3 \\
\hline 39. & Coumaphos & 3.9 & 40. & Oryzalin & 2.9 \\
\hline 41. & Cyazofamid & 9.4 & 42. & Oxadiazon & 4.9 \\
\hline 43. & Cyfluthrin & 25.0 & 44. & Oxyfluorfen & 20.0 \\
\hline 45. & Cypermethrin & 10.0 & 46. & Parathion & 24.0 \\
\hline 47. & Cyprodinil & 30.0 & 48. & Pendimethalin & 37.0 \\
\hline 49. & Allethrin (d-cis,trans) & 11.0 & 50. & Phosalone & 9.9 \\
\hline 51. & Diazinon & 33.0 & 52. & Piperonyl butoxide & 15.0 \\
\hline 53. & Dichlobenil & 58.0 & 54. & Pirimiphos-methyl & 12.0 \\
\hline 55. & Diclosulam & 34.0 & 56. & Prallethrin & 3.6 \\
\hline 57. & $\begin{array}{l}\text { MEHP (Phthalic acid, } \\
\text { mono-2-ethylhexyl } \\
\text { ester) }\end{array}$ & 62.0 & 58. & Prochloraz & 3.6 \\
\hline 59. & $\begin{array}{l}\text { DEHP (Diethylhexyl } \\
\text { phthalate) }\end{array}$ & 38.0 & 60. & Prodiamine & 5.7 \\
\hline 61. & Disulfoton & 38.0 & 62. & Profenofos & 5.0 \\
\hline 63. & Dithiopyr & 2.3 & 64. & Prometryn & 25.0 \\
\hline 65. & Diuron & 58.0 & 66. & Propazine & 34.0 \\
\hline 67. & S-Bioallethrin & 3.6 & 68. & Propetamphos & 7.1 \\
\hline 69. & Esfenvalerate & 4.6 & 70. & Propyzamide & 39.0 \\
\hline 71. & Ethalfluralin & 17.0 & 72. & Pyraflufen-ethyl & 29.0 \\
\hline
\end{tabular}




\begin{tabular}{llc|clc}
\hline 73. & Ethofumesate & 37.0 & 74. & Resmethrin & 23.0 \\
\hline 75. & Etoxazole & 3.3 & 76. & Sulfentrazone & 34.0 \\
\hline 77. & Fenamidone & 47.0 & 78. & Tebupirimfos & 13.0 \\
\hline 79. & Fenamiphos & 14.0 & 80. & Tetramethrin & 43.0 \\
\hline 81. & Fenarimol & 49.0 & 82. & Thiazopyr & 0.5 \\
\hline 83. & Fenhexamid & 24.0 & 84. & Thiobencarb & 25.0 \\
\hline 85. & Fenitrothion & 47.0 & 86. & Triadimefon & 26.0 \\
\hline 87. & Fenpropathrin & 11.0 & 88. & Triadimenol & 4.4 \\
\hline 89. & Fenpyroximate $(Z, E)$ & 12.0 & 90. & Tri-allate & 25.0 \\
\hline 91. & Fenthion & 39.0 & 92. & Triasulfuron & 22.0 \\
\hline 93. & Fipronil & 28.0 & 94. & Tribufos & 23.0 \\
\hline 95. & Fludioxonil & 23.0 & 96. & Trifloxystrobin & 60.0 \\
\hline 97. & Flufenacet & 13.0 & 98. & Trifluralin & 14.0 \\
\hline 99. & Flumetralin & 4.3 & 100. & Triticonazole & 10.0 \\
\hline 101. & Flusilazole & 36.0 & 102. & Zoxamide & 2.2 \\
\hline
\end{tabular}

Chemicals are arranged in alphabetic order. 


\section{APPENDIX 11}

Pesticides associated Activate hPXR in NVS_NR_hPXR ToxCastDB.

\begin{tabular}{|c|c|c|c|c|c|}
\hline \# & Name of Chemical & $\begin{array}{l}\text { Dose } \\
(\mu \mathrm{M})\end{array}$ & \# & Name of Chemical & $\begin{array}{l}\text { Dose } \\
(\mu \mathrm{M})\end{array}$ \\
\hline 1. & HPTE & 23.0 & 2. & Malathion & 22.0 \\
\hline 3. & $\begin{array}{l}\text { 3-lodo-2- } \\
\text { propynylbutylcarbamate }\end{array}$ & 6.9 & 4. & Mancozeb & 1.5 \\
\hline 5. & $\begin{array}{l}\text { 3-lodo-2- } \\
\text { propynylbutylcarbamate }\end{array}$ & 15.0 & 6. & Maneb & 0.11 \\
\hline 7. & Abamectin & 18.0 & 8. & Methamidophos & 21.0 \\
\hline 9. & Alachlor & 8.6 & 10. & Methidathion & 15.0 \\
\hline 11. & Azinphos-methyl & 18.0 & 12. & Methoxyfenozide & 5.9 \\
\hline 13. & Azoxystrobin & 4.7 & 14. & $\begin{array}{l}\text { Methylene } \\
\text { bis(thiocyanate) }\end{array}$ & 2.2 \\
\hline 15. & Bensulide & 0.62 & 16. & Metiram-zinc & 3.3 \\
\hline 17. & Bensulide & 0.69 & 18. & $\begin{array}{l}\text { Milbemectin } \\
\text { (mixture) }\end{array}$ & 6.4 \\
\hline 19. & Bensulide & 1.0 & 20. & Napropamide & 0.18 \\
\hline 21. & Buprofezin & 5.5 & 22. & Oryzalin & 4.5 \\
\hline 23. & Butachlor & 1.3 & 24. & Oxadiazon & 7.5 \\
\hline 25. & Butafenacil & 2.4 & 26. & Pendimethalin & 15.0 \\
\hline 27. & Butylate & 47.0 & 28. & $\begin{array}{l}\text { PFOS } \\
\text { (Perfluorooctane } \\
\text { sulfonic acid) }\end{array}$ & 38.0 \\
\hline 29. & Cacodylic acid & 15.0 & 30. & Permethrin & 29.0 \\
\hline 31. & Captan & 3.5 & 32. & Phosalone & 10.0 \\
\hline 33. & Chlorpyrifos oxon & 19.0 & 34. & Pirimiphos-methyl & 9.4 \\
\hline 35. & Clodinafop-propargyl & 5.5 & 36. & Prallethrin & 25.0 \\
\hline 37. & Clothianidin & 19.0 & 38. & Prochloraz & 5.0 \\
\hline 39. & Coumaphos & 6.5 & 40. & Profenofos & 27.0 \\
\hline 41. & Cyclanilide & 13.0 & 42. & Prometryn & 13.0 \\
\hline 43. & Cyprodinil & 48.0 & 44. & Propargite & 20.0 \\
\hline 45. & Dimethenamid & 39.0 & 46. & Propetamphos & 46.0 \\
\hline 47. & Diniconazole & 20.0 & 48. & Propiconazole & 14.0 \\
\hline 49. & Dithiopyr & 0.31 & 50. & Pymetrozine & 17.0 \\
\hline 51. & Emamectin benzoate & 7.1 & 52. & Pyraclostrobin & 7.0 \\
\hline 53. & Ethalfluralin & 8.1 & 54. & Resmethrin & 6.6 \\
\hline 55. & Etoxazole & 12.0 & 56. & Spirodiclofen & 0.43 \\
\hline 57. & Fenarimol & 18.0 & 58. & TCMTB & 1.6 \\
\hline
\end{tabular}




\begin{tabular}{clc|clc}
\hline 59. & Fenhexamid & 1.9 & 60. & Tebupirimfos & 35.0 \\
\hline 61. & Fentin & 0.86 & 62. & Tetraconazole & 44.0 \\
\hline 63. & Fluazifop-butyl & 21.0 & 64. & Tetramethrin & 18.0 \\
\hline 65. & Fluazinam & 0.26 & 66. & Thiazopyr & 0.17 \\
\hline 67. & Flufenacet & 14.0 & 68. & Thiobencarb & 28.0 \\
\hline 69. & Flumetralin & 1.8 & 70. & Thiodicarb & 1.1 \\
\hline 71. & Flumiclorac-pentyl & 2.1 & 72. & Thiophanate-methyl & 48.0 \\
\hline 73. & Fluoxastrobin & 12.0 & 74. & Thiram & 12.0 \\
\hline 75. & Flutolanil & 7.1 & 76. & Triadimefon & 7.6 \\
\hline 77. & Folpet & 8.2 & 78. & Tri-allate & 9.7 \\
\hline 79. & Fosthiazate & 49.0 & 80. & Tribufos & 40.0 \\
\hline 81. & Hexaconazole & 49.0 & 82. & Triclosan & 13.0 \\
\hline 83. & Indoxacarb & 3.2 & 84. & Triflumizole & 38.0 \\
\hline 85. & Isazofos & 16.0 & 86. & Trifluralin & 28.0 \\
\hline 87. & Isoxaben & 0.45 & 88. & Triflusulfuron-methyl & 34.0 \\
\hline 89. & Lindane & 27.0 & 90. & Vinclozolin & 6.7 \\
\hline 91. & Malaoxon & 33.0 & & & \\
\hline
\end{tabular}

Chemicals are arranged in alphabetic order. 


\section{APPENDIX 12}

Pesticides associated Activate hPXR target gene CYP 3a4 in CLZD_CYP3A4 ToxCastDB.

\begin{tabular}{|c|c|c|c|c|c|}
\hline \# & Name of Chemical & $\begin{array}{l}\text { Dose } \\
(\mu \mathrm{M})\end{array}$ & \# & Name of Chemical & $\begin{array}{l}\text { Dose } \\
(\mu \mathrm{M})\end{array}$ \\
\hline 1. & $\begin{array}{l}\text { 3-Iodo-2- } \\
\text { propynylbutylcarbamate }\end{array}$ & 0.58 & 2. & Imazalil & 0.588 \\
\hline 3. & Abamectin & 5.65 & 4. & Imazapyr & 1.13 \\
\hline 5. & Acetochlor & $\begin{array}{c}0.396 \\
5.67 \\
0.598\end{array}$ & 6. & Imazethapyr & 14.1 \\
\hline 7. & Acifluorfen & 9.15 & 8. & Imidacloprid & 29.2 \\
\hline 9. & Alachlor & $\begin{array}{l}2.99 \\
4.03\end{array}$ & 10. & Indoxacarb & $\begin{array}{c}0.467 \\
8.39 \\
10.2\end{array}$ \\
\hline 11. & Ametryn & $\begin{array}{l}5.21 \\
6.23 \\
\end{array}$ & 12. & Iprodione & $\begin{array}{l}5.77 \\
13.1 \\
\end{array}$ \\
\hline 13. & Asulam & 9.64 & 14. & Isazofos & $\begin{array}{c}0.46 \\
0.788 \\
2.75 \\
\end{array}$ \\
\hline 15. & Atrazine & $\begin{array}{l}10.9 \\
12.6 \\
28.8 \\
\end{array}$ & 16. & Isoxaben & $\begin{array}{c}0.0992 \\
0.225 \\
1.17\end{array}$ \\
\hline 17. & Azinphos-methyl & $\begin{array}{l}0.493 \\
6.12 \\
7.13\end{array}$ & 18. & Isoxaflutole & $\begin{array}{l}6.99 \\
16.1\end{array}$ \\
\hline 19. & Azoxystrobin & $\begin{array}{l}10.2 \\
11.8\end{array}$ & 20. & Lactofen & $\begin{array}{c}5.12 \\
7.73 \\
9.5\end{array}$ \\
\hline 21. & Benfluralin & $\begin{array}{l}7.39 \\
11.2 \\
12.1\end{array}$ & 22. & Lindane & $\begin{array}{l}1.45 \\
4.05\end{array}$ \\
\hline 23. & Bensulide & $\begin{array}{c}0.472 \\
1.08 \\
2.45\end{array}$ & 24. & Linuron & $\begin{array}{l}5.44 \\
12.9\end{array}$ \\
\hline 25. & Bensulide & $\begin{array}{l}0.783 \\
0.649 \\
\end{array}$ & 26. & Malaoxon & $\begin{array}{l}5.31 \\
11.3 \\
\end{array}$ \\
\hline 27. & Bensulide & $\begin{array}{c}0.469 \\
0.659 \\
12.0 \\
\end{array}$ & 28. & Malathion & 0.0635 \\
\hline 29. & Bifenazate & 0.9 & 30. & Mancozeb & 6.51 \\
\hline 31. & Bifenthrin & $\begin{array}{l}4.16 \\
4.65 \\
11.9 \\
\end{array}$ & 32. & Metalaxyl & $\begin{array}{l}8.73 \\
10.4\end{array}$ \\
\hline
\end{tabular}




\begin{tabular}{|c|c|c|c|c|c|}
\hline 33. & Bisphenol A & 3.53 & 34. & Methidathion & $\begin{array}{l}5.26 \\
9.62 \\
\end{array}$ \\
\hline 35. & Boscalid & $\begin{array}{l}1.17 \\
5.67 \\
10.5 \\
\end{array}$ & 36. & Methoxychlor & $\begin{array}{l}6.58 \\
14.0 \\
20.3 \\
\end{array}$ \\
\hline 37. & Bromacil & $\begin{array}{l}6.29 \\
8.82\end{array}$ & 38. & Methoxyfenozide & $\begin{array}{c}0.729 \\
6.02 \\
7.2 \\
\end{array}$ \\
\hline 39. & Buprofezin & $\begin{array}{l}10.8 \\
11.9\end{array}$ & 40. & Metolachlor & $\begin{array}{c}0.488 \\
9.61 \\
12.3 \\
\end{array}$ \\
\hline 41. & Butachlor & 8.35 & 42. & Metribuzin & 3.95 \\
\hline 43. & Butafenacil & $\begin{array}{l}0.296 \\
0.512 \\
3.87\end{array}$ & 44. & MGK & $\begin{array}{l}12.2 \\
17.7\end{array}$ \\
\hline 45. & Butralin & $\begin{array}{l}2.16 \\
4.31 \\
5.15\end{array}$ & 46. & $\begin{array}{l}\text { Milbemectin } \\
\text { (mixture) }\end{array}$ & $\begin{array}{c}0.442 \\
0.447 \\
29.2\end{array}$ \\
\hline 47. & Butylate & 0.951 & 48. & Molinate & 6.28 \\
\hline 49. & Carbaryl & 8.42 & 50. & Myclobutanil & $\begin{array}{l}5.24 \\
5.93 \\
6.07\end{array}$ \\
\hline 51. & Carboxin & $\begin{array}{l}5.35 \\
8.35 \\
\end{array}$ & 52. & Napropamide & $\begin{array}{l}4.43 \\
28.3\end{array}$ \\
\hline 53. & Carfentrazone-ethyl & $\begin{array}{l}10.3 \\
12.1\end{array}$ & 54. & Nitrapyrin & 0.424 \\
\hline 55. & Chlorethoxyfos & $\begin{array}{l}8.24 \\
8.49 \\
10.3 \\
\end{array}$ & 56. & Norflurazon & $\begin{array}{l}4.37 \\
5.42 \\
12.2\end{array}$ \\
\hline 57. & Chloroneb & 0.542 & 58. & Oryzalin & $\begin{array}{l}12.6 \\
12.7\end{array}$ \\
\hline 59. & Chlorpropham & $\begin{array}{l}9.29 \\
13.7 \\
27.7 \\
\end{array}$ & 60. & Oxadiazon & $\begin{array}{l}0.568 \\
0.586\end{array}$ \\
\hline 61. & Chlorpyrifos oxon & $\begin{array}{l}5.21 \\
7.71 \\
\end{array}$ & 62. & Oxasulfuron & 29.2 \\
\hline 63. & Chlorpyrifos-methyl & 12.1 & 64. & Oxyfluorfen & $\begin{array}{l}5.87 \\
8.47 \\
10.7 \\
\end{array}$ \\
\hline 65. & Chlorsulfuron & 1.69 & 66. & $\begin{array}{l}\text { Oxytetracycline } \\
\text { dihydrate }\end{array}$ & 5.35 \\
\hline 67. & Cinmethylin & $\begin{array}{l}7.65 \\
12.8 \\
\end{array}$ & 68. & Paclobutrazol & 7.6 \\
\hline 69. & Clodinafop-propargyl & 28.7 & 70. & Parathion & $\begin{array}{l}4.88 \\
5.27 \\
11.9 \\
\end{array}$ \\
\hline
\end{tabular}




\begin{tabular}{|c|c|c|c|c|c|}
\hline 71. & Clofentezine & $\begin{array}{c}5.0 \\
5.17 \\
10.1\end{array}$ & 72. & Parathion-methyl & $\begin{array}{l}3.61 \\
12.5\end{array}$ \\
\hline 73. & Clomazone & $\begin{array}{l}9.04 \\
28.3 \\
\end{array}$ & 74. & Pendimethalin & 18.5 \\
\hline 75. & Clopyralid-olamine & $\begin{array}{l}4.87 \\
9.73\end{array}$ & 76. & Penoxsulam & $\begin{array}{l}6.61 \\
11.0 \\
11.7 \\
\end{array}$ \\
\hline 77. & Coumaphos & $\begin{array}{l}2.87 \\
3.47\end{array}$ & 78. & $\begin{array}{l}\text { PFOS } \\
\text { (Perfluorooctane } \\
\text { sulfonic acid) }\end{array}$ & $\begin{array}{l}28.8 \\
28.9\end{array}$ \\
\hline 79. & Cyanazine & $\begin{array}{l}5.87 \\
5.94\end{array}$ & 80. & $\begin{array}{l}\text { PFOA } \\
\text { (Perfluorooctanoic } \\
\text { acid) }\end{array}$ & 2.37 \\
\hline 81. & Cyfluthrin & $\begin{array}{l}12.3 \\
28.5 \\
\end{array}$ & 82. & Permethrin & 2.15 \\
\hline 83. & Cypermethrin & $\begin{array}{l}4.44 \\
11.2 \\
12.7 \\
\end{array}$ & 84. & Phosalone & 7.94 \\
\hline 85. & Cyproconazole & $\begin{array}{l}7.68 \\
9.77\end{array}$ & 86. & Piperonyl butoxide & $\begin{array}{l}2.23 \\
2.97 \\
9.62\end{array}$ \\
\hline 87. & Cyprodinil & 28.0 & 88. & Pirimicarb & 6.5 \\
\hline 89. & Cyromazine & 5.06 & 90. & Pirimiphos-methyl & $\begin{array}{l}5.24 \\
10.6\end{array}$ \\
\hline 91. & Allethrin (d-cis,trans) & 6.31 & 92. & Prallethrin & $\begin{array}{l}3.56 \\
6.53 \\
14.6\end{array}$ \\
\hline 93. & Diazinon & $\begin{array}{l}0.532 \\
4.18 \\
4.63 \\
\end{array}$ & 94. & Prodiamine & $\begin{array}{l}0.494 \\
5.65 \\
13.6 \\
\end{array}$ \\
\hline 95. & Diazoxon & $\begin{array}{l}9.92 \\
29.6 \\
\end{array}$ & 96. & Profenofos & $\begin{array}{l}6.73 \\
8.97 \\
\end{array}$ \\
\hline 97. & DBP (Dibutyl phthalate) & 4.17 & 98. & Prometon & $\begin{array}{l}3.05 \\
4.85 \\
11.1\end{array}$ \\
\hline 99. & Dichlobenil & 0.408 & 100. & Prometryn & $\begin{array}{l}7.19 \\
6.98\end{array}$ \\
\hline 101. & Dichloran & 6.07 & 102. & Propanil & 12.4 \\
\hline 103. & Diclofop-methyl & 10.3 & 104. & Propargite & 1.59 \\
\hline 105. & Diclosulam & $\begin{array}{c}5.97 \\
8.6\end{array}$ & 106. & Propazine & $\begin{array}{l}5.66 \\
7.8 \\
7.11 \\
\end{array}$ \\
\hline 107. & Dicofol & $\begin{array}{c}5.87 \\
6.9 \\
13.6 \\
\end{array}$ & 108. & Propetamphos & $\begin{array}{l}1.03 \\
3.17 \\
4.91\end{array}$ \\
\hline
\end{tabular}




\begin{tabular}{|c|c|c|c|c|}
\hline $\begin{array}{l}\text { MEHP (Phthalic acid, } \\
\text { 109. mono-2-ethylhexyl } \\
\text { ester) }\end{array}$ & $\begin{array}{l}5.77 \\
11.9\end{array}$ & 110. & Propiconazole & $\begin{array}{l}0.533 \\
2.96\end{array}$ \\
\hline 111. Diethyltoluamide & $\begin{array}{l}4.62 \\
11.1 \\
12.4\end{array}$ & 112. & Propoxur & $\begin{array}{l}7.04 \\
8.81\end{array}$ \\
\hline 113. Dimethenamid & $\begin{array}{l}5.32 \\
6.19 \\
6.85\end{array}$ & 114. & $\begin{array}{l}\text { Propoxycarbazone- } \\
\text { sodium }\end{array}$ & 28.0 \\
\hline 115. Dimethomorph & $\begin{array}{l}0.503 \\
3.36 \\
3.62 \\
\end{array}$ & 116. & Propyzamide & $\begin{array}{c}8.7 \\
23.9\end{array}$ \\
\hline 117. Diniconazole & $\begin{array}{l}0.513 \\
0.612 \\
2.63\end{array}$ & 118. & Prosulfuron & $\begin{array}{l}6.34 \\
9.19\end{array}$ \\
\hline 119. Disulfoton & $\begin{array}{l}14.8 \\
16.8 \\
26.7\end{array}$ & 120. & Prosulfuron & $\begin{array}{l}4.01 \\
4.59\end{array}$ \\
\hline 121. Dithiopyr & $\begin{array}{l}1.29 \\
2.62\end{array}$ & 122. & Prosulfuron & 5.36 \\
\hline 123. Diuron & $\begin{array}{l}5.27 \\
9.37\end{array}$ & 124. & Pyraclostrobin & 4.62 \\
\hline 125. S-Bioallethrin & $\begin{array}{l}8.75 \\
9.7 \\
13.3\end{array}$ & 126. & Pyraflufen-ethyl & $\begin{array}{l}5.03 \\
7.28 \\
11.6 \\
\end{array}$ \\
\hline 127. Endosulfan & $\begin{array}{l}5.15 \\
6.45 \\
8.57\end{array}$ & 128. & Pyrimethanil & $\begin{array}{l}6.48 \\
9.18\end{array}$ \\
\hline 129. Esfenvalerate & $\begin{array}{c}3.37 \\
8.1 \\
15.0\end{array}$ & 130. & Pyriproxyfen & $\begin{array}{l}8.01 \\
12.2 \\
27.8\end{array}$ \\
\hline 131. Ethalfluralin & $\begin{array}{l}5.17 \\
13.7\end{array}$ & 132. & Pyrithiobac-sodium & $\begin{array}{l}10.9 \\
13.4\end{array}$ \\
\hline 133. Ethametsulfuron methyl & 0.461 & 134. & Quinoxyfen & 9.68 \\
\hline 135. Ethofumesate & $\begin{array}{c}7.0 \\
10.1\end{array}$ & 136. & Quintozene & 3.99 \\
\hline 137. Ethoprop & $\begin{array}{c}4.43 \\
7.0\end{array}$ & 138. & Resmethrin & 4.78 \\
\hline 139. Etoxazole & $\begin{array}{l}2.23 \\
4.64 \\
7.19\end{array}$ & 140. & Rimsulfuron & 9.4 \\
\hline 141. Fenamiphos & $\begin{array}{l}5.55 \\
5.77\end{array}$ & 142. & Rotenone & 1.5 \\
\hline 143. Fenarimol & $\begin{array}{l}0.461 \\
0.589\end{array}$ & 144. & Sethoxydim & $\begin{array}{l}5.59 \\
5.92 \\
27.8\end{array}$ \\
\hline
\end{tabular}




\begin{tabular}{|c|c|c|c|c|}
\hline 145. Fenbuconazole & $\begin{array}{l}1.06 \\
2.02 \\
\end{array}$ & 146. & Spirodiclofen & $\begin{array}{c}0.437 \\
25.6 \\
\end{array}$ \\
\hline 147. Fenhexamid & 0.0165 & 148. & Spiroxamine & $\begin{array}{c}4.3 \\
6.42 \\
6.83 \\
\end{array}$ \\
\hline 149. Fenitrothion & $\begin{array}{l}7.39 \\
7.87\end{array}$ & 150. & Sulfentrazone & $\begin{array}{l}1.61 \\
3.38 \\
7.26 \\
\end{array}$ \\
\hline 151. Fenoxaprop-ethyl & 5.52 & 152. & Tebufenozide & $\begin{array}{c}0.972 \\
5.17 \\
6.75\end{array}$ \\
\hline 153. Fenpropathrin & $\begin{array}{l}4.46 \\
5.13 \\
13.3\end{array}$ & 154. & Tebufenpyrad & $\begin{array}{l}6.05 \\
24.6\end{array}$ \\
\hline 155. Fenthion & $\begin{array}{l}4.25 \\
14.7\end{array}$ & 156. & Tebupirimfos & $\begin{array}{c}0.558 \\
1.46 \\
0.446\end{array}$ \\
\hline 157. Fentin & 4.0 & 158. & Tefluthrin & $\begin{array}{c}4.5 \\
10.5 \\
\end{array}$ \\
\hline 159. Fipronil & $\begin{array}{l}0.568 \\
0.757\end{array}$ & 160. & Tetraconazole & $\begin{array}{l}0.495 \\
0.471\end{array}$ \\
\hline 161. Fluazifop-butyl & 12.0 & 162. & Tetramethrin & $\begin{array}{l}3.63 \\
7.09 \\
\end{array}$ \\
\hline 163. Fluazinam & 0.475 & 164. & Thiacloprid & 9.55 \\
\hline 165. Fludioxonil & $\begin{array}{l}6.97 \\
9.63\end{array}$ & 166. & Thiamethoxam & 9.18 \\
\hline 167. Flufenacet & 7.59 & 168. & Thiazopyr & $\begin{array}{c}0.547 \\
12.7 \\
\end{array}$ \\
\hline 169. Flufenpyr-ethyl & $\begin{array}{l}6.69 \\
7.86 \\
9.98 \\
\end{array}$ & 170. & Thidiazuron & 5.9 \\
\hline 171. Flumetralin & $\begin{array}{c}0.51 \\
3.44 \\
5.6 \\
\end{array}$ & 172. & Thiobencarb & $\begin{array}{l}4.47 \\
12.1\end{array}$ \\
\hline 173. Flumetsulam & $\begin{array}{l}11.3 \\
15.4 \\
16.0 \\
\end{array}$ & 174. & Thiophanate-methyl & $\begin{array}{l}5.09 \\
4.89 \\
8.36 \\
\end{array}$ \\
\hline 175. Flumiclorac-pentyl & 6.37 & 176. & Tralkoxydim & $\begin{array}{l}5.84 \\
5.97 \\
14.6 \\
\end{array}$ \\
\hline 177. Flumioxazin & 4.77 & 178. & Triadimefon & $\begin{array}{l}5.67 \\
5.82 \\
\end{array}$ \\
\hline 179. Fluometuron & $\begin{array}{l}0.42 \\
10.2\end{array}$ & 180. & Triadimenol & $\begin{array}{c}0.408 \\
2.39 \\
3.62\end{array}$ \\
\hline 181. Fluoxastrobin & 0.27 & 182. & Tri-allate & 5.61 \\
\hline
\end{tabular}




\begin{tabular}{|c|c|c|c|c|}
\hline & 0.475 & & & 7.08 \\
\hline 183. Flusilazole & 0.62 & 184. & Triasulfuron & $\begin{array}{l}4.41 \\
5.91\end{array}$ \\
\hline 185. Fluthiacet-methyl & $\begin{array}{l}2.43 \\
4.79 \\
5.32 \\
\end{array}$ & 186. & Tribufos & $\begin{array}{l}0.523 \\
12.5\end{array}$ \\
\hline 187. Flutolanil & $\begin{array}{l}12.1 \\
12.8\end{array}$ & 188. & Triclosan & 4.39 \\
\hline 189. Forchlorfenuron & 28.2 & 190. & Trifloxystrobin & $\begin{array}{l}11.8 \\
12.6 \\
\end{array}$ \\
\hline 191. Fosthiazate & $\begin{array}{l}10.0 \\
12.2 \\
12.7 \\
\end{array}$ & 192. & $\begin{array}{l}\text { Trifloxysulfuron- } \\
\text { sodium }\end{array}$ & 7.44 \\
\hline 193. Halosulfuron-methyl & $\begin{array}{l}4.54 \\
7.12 \\
\end{array}$ & 194. & Triflumizole & $\begin{array}{l}0.534 \\
0.764 \\
\end{array}$ \\
\hline 195. Hexaconazole & $\begin{array}{l}3.37 \\
5.33\end{array}$ & 196. & Trifluralin & $\begin{array}{l}3.31 \\
11.0 \\
11.6 \\
\end{array}$ \\
\hline 197. Hexazinone & $\begin{array}{l}4.37 \\
8.64 \\
\end{array}$ & 198. & Triflusulfuron-methyl & 11.8 \\
\hline 199. Hexythiazox & $\begin{array}{c}3.2 \\
3.93 \\
\end{array}$ & 200. & Triticonazole & $\begin{array}{l}1.56 \\
4.09 \\
\end{array}$ \\
\hline 201. Icaridin & 6.82 & 202. & Zoxamide & $\begin{array}{l}4.87 \\
7.55\end{array}$ \\
\hline
\end{tabular}

Chemicals are arranged in alphabetic order. 


\section{APPENDIX 13}

Pesticides associated Activate hPXR target gene CYP3A4 in NVS_ADME_hCYP3A4 ToxCastDB.

\begin{tabular}{llc|clc}
\hline$\#$ & Name of Chemical & $\begin{array}{c}\text { Dose } \\
(\mu \mathrm{M})\end{array}$ & $\#$ Name of Chemical & $\begin{array}{c}\text { Dose } \\
(\boldsymbol{\mu M})\end{array}$ \\
\hline 1. & HPTE & 13.0 & 2. & Imazalil & 0.1 \\
\hline 3. & Bensulide & 0.37 & 4. & Malathion & 4.4 \\
\hline 5. & Bensulide & 0.49 & 6. & MGK & 3.1 \\
\hline 7. & Bensulide & 0.7 & 8. & Milbemectin (mixture) & 9.6 \\
\hline 9. & Chlorothalonil & 0.39 & 10. & Paclobutrazol & 4.3 \\
\hline 11. & Cyproconazole & 5.7 & 12. & Piperonyl butoxide & 0.95 \\
\hline 13. & Diniconazole & 1.3 & 14. & Tetraconazole & 18.0 \\
\hline 15. & Fenarimol & 16.0 & 16. & Triflumizole & 0.46 \\
\hline 17. & Fenbuconazole & 5.7 & & & \\
\hline
\end{tabular}

Chemicals are arranged in alphabetic order. 


\section{APPENDIX 14}

Pesticides associated Activate PXR and CYP3a4 in humans in ToxCastDB.

\begin{tabular}{|c|c|c|c|c|c|}
\hline$\#$ & Name of Chemical & $\begin{array}{l}\text { Dose } \\
(\mu \mathrm{M})\end{array}$ & \# & $\begin{array}{l}\text { Name of } \\
\text { Chemical }\end{array}$ & $\begin{array}{l}\text { Dose } \\
(\mu \mathrm{M})\end{array}$ \\
\hline 1. & $\begin{array}{l}\text { 3-lodo-2- } \\
\text { propynylbutylcarbamate }\end{array}$ & $\begin{array}{c}6.9 \\
15.0 \\
0.58\end{array}$ & 2. & Imazethapyr & 14.1 \\
\hline 3. & Abamectin & $\begin{array}{c}0.598 \\
5.65 \\
18.0 \\
\end{array}$ & 4. & Imidacloprid & $\begin{array}{l}29.2 \\
72.0\end{array}$ \\
\hline 5. & Acetochlor & $\begin{array}{c}0.396 \\
5.67 \\
0.598\end{array}$ & 6. & Indoxacarb & $\begin{array}{c}0.467 \\
3.2 \\
7.96 \\
7.3 \\
8.39 \\
10.2 \\
\end{array}$ \\
\hline 7. & Acifluorfen & $\begin{array}{c}2.99 \\
4.03 \\
5.7 \\
8.6 \\
9.15 \\
15.4 \\
\end{array}$ & 8. & Iprodione & $\begin{array}{l}5.77 \\
11.0 \\
13.1\end{array}$ \\
\hline 9. & Allethrin (d-cis,trans) & $\begin{array}{l}6.31 \\
11.0 \\
11.1\end{array}$ & 10. & Isazofos & $\begin{array}{c}0.46 \\
0.788 \\
2.75 \\
4.5 \\
5.53 \\
16.0\end{array}$ \\
\hline 11. & Ametryn & $\begin{array}{l}6.23 \\
5.21 \\
34.0\end{array}$ & 12. & Isoxaben & $\begin{array}{c}0.225 \\
0.0992 \\
0.45 \\
0.479 \\
1.0 \\
1.17\end{array}$ \\
\hline 13. & Asulam & 9.64 & 14. & Isoxaflutole & $\begin{array}{l}6.99 \\
16.1\end{array}$ \\
\hline 15. & Atrazine & $\begin{array}{l}10.9 \\
12.6 \\
28.8\end{array}$ & 16. & Lactofen & $\begin{array}{c}5.12 \\
7.73 \\
9.5 \\
26.0\end{array}$ \\
\hline 17. & Azinphos-methyl & $\begin{array}{l}0.493 \\
6.12\end{array}$ & 18. & Lindane & $\begin{array}{l}1.45 \\
4.05\end{array}$ \\
\hline
\end{tabular}




\begin{tabular}{|c|c|c|c|}
\hline & $\begin{array}{l}7.13 \\
18.0\end{array}$ & & $\begin{array}{l}22.0 \\
27.0\end{array}$ \\
\hline 19. Azoxystrobin & $\begin{array}{c}4.3 \\
4.7 \\
10.2 \\
11.8 \\
\end{array}$ & 20. Linuron & $\begin{array}{l}5.44 \\
12.9 \\
40.0\end{array}$ \\
\hline 21. Benfluralin & $\begin{array}{l}7.39 \\
11.2 \\
12.1 \\
32.0\end{array}$ & 22. Malaoxon & $\begin{array}{l}5.31 \\
11.3 \\
33.0\end{array}$ \\
\hline 23. Bensulide & $\begin{array}{c}0.37 \\
0.469 \\
0.472 \\
0.49 \\
0.56 \\
0.62 \\
0.649 \\
0.659 \\
0.69 \\
0.7 \\
0.783 \\
0.91 \\
1.0 \\
1.08 \\
1.4 \\
1.57 \\
2.45 \\
12.0 \\
\end{array}$ & 24. Malathion & $\begin{array}{c}0.0635 \\
4.4 \\
22.0 \\
31.0\end{array}$ \\
\hline 25. Bentazone & 47.0 & 26. Mancozeb & $\begin{array}{c}1.5 \\
6.51\end{array}$ \\
\hline 27. Bifenazate & $\begin{array}{c}0.9 \\
11.0\end{array}$ & 28. Maneb & 0.11 \\
\hline 29. Bifenthrin & $\begin{array}{c}4.1 \\
4.16 \\
4.65 \\
11.9 \\
28.4 \\
\end{array}$ & 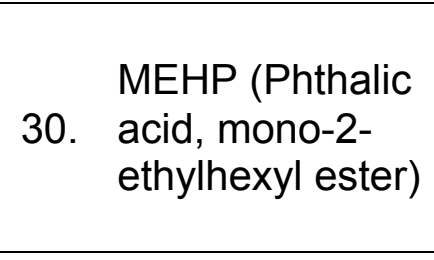 & $\begin{array}{l}5.77 \\
11.9 \\
62.0\end{array}$ \\
\hline 31. Bisphenol A & $\begin{array}{l}3.53 \\
14.0 \\
20.5\end{array}$ & 32. Metalaxyl & $\begin{array}{l}8.73 \\
10.4 \\
14.0\end{array}$ \\
\hline 33. Boscalid & $\begin{array}{l}1.17 \\
5.67 \\
10.5\end{array}$ & $\begin{array}{l}\text { 34. Metam-sodium } \\
\text { hydrate }\end{array}$ & 31.4 \\
\hline 35. Bromacil & 6.29 & 36. Methamidophos & 21.0 \\
\hline
\end{tabular}




\begin{tabular}{|c|c|c|c|}
\hline & 8.82 & & \\
\hline 37. Buprofezin & $\begin{array}{c}3.8 \\
5.44 \\
5.5 \\
10.8 \\
11.9\end{array}$ & 38. Methidathion & $\begin{array}{l}5.26 \\
9.62 \\
15.0\end{array}$ \\
\hline 39. Butachlor & $\begin{array}{c}1.1 \\
1.3 \\
1.95 \\
8.35\end{array}$ & 40. Methoxychlor & $\begin{array}{l}6.58 \\
14.0 \\
20.3\end{array}$ \\
\hline 41. Butafenacil & $\begin{array}{c}0.296 \\
0.512 \\
2.4 \\
3.87\end{array}$ & 42. Methoxyfenozide & $\begin{array}{c}0.729 \\
2.4 \\
5.9 \\
5.99 \\
6.02 \\
7.2 \\
\end{array}$ \\
\hline 43. Butralin & $\begin{array}{c}0.951 \\
2.16 \\
4.31 \\
5.15 \\
7.7 \\
36.1 \\
47.0\end{array}$ & $\begin{array}{l}\text { Methylene } \\
\text { bis(thiocyanate) }\end{array}$ & 2.2 \\
\hline 45. Cacodylic acid & 15.0 & 46. Metiram-zinc & 3.3 \\
\hline 47. Captan & 3.5 & 48. Metolachlor & $\begin{array}{c}0.488 \\
0.517 \\
6.6 \\
9.61 \\
12.3\end{array}$ \\
\hline 49. Carbaryl & 8.42 & 50. Metribuzin & 3.95 \\
\hline 51. Carboxin & $\begin{array}{l}5.35 \\
8.35\end{array}$ & 52. MGK & $\begin{array}{c}3.1 \\
12.2 \\
17.7 \\
18.0 \\
\end{array}$ \\
\hline 53. Carfentrazone-ethyl & $\begin{array}{l}10.3 \\
12.1 \\
43.0\end{array}$ & 54. $\begin{array}{l}\text { Milbemectin } \\
\text { (mixture) }\end{array}$ & $\begin{array}{c}0.442 \\
0.447 \\
6.4 \\
9.6 \\
29.2\end{array}$ \\
\hline 55. Chlorethoxyfos & $\begin{array}{l}8.24 \\
8.49 \\
10.3\end{array}$ & 56. Molinate & $\begin{array}{l}6.28 \\
62.0\end{array}$ \\
\hline 57. Chloroneb & 0.542 & 58. Myclobutanil & $\begin{array}{l}6.07 \\
5.24\end{array}$ \\
\hline
\end{tabular}




\begin{tabular}{|c|c|c|c|}
\hline & & & 5.93 \\
\hline 59. Chlorothalonil & $\begin{array}{l}0.39 \\
0.22 \\
17.7\end{array}$ & 60. Napropamide & $\begin{array}{c}0.18 \\
0.479 \\
1.3 \\
4.43 \\
28.3\end{array}$ \\
\hline 61. Chlorpropham & $\begin{array}{l}9.29 \\
13.7 \\
27.7 \\
45.0\end{array}$ & 62. Nitrapyrin & 0.424 \\
\hline 63. Chlorpyrifos oxon & $\begin{array}{l}5.21 \\
7.71 \\
19.0 \\
\end{array}$ & 64. Norflurazon & $\begin{array}{l}4.37 \\
5.42 \\
12.2 \\
\end{array}$ \\
\hline 65. Chlorpyrifos-methyl & 12.1 & 66. Oryzalin & $\begin{array}{c}2.9 \\
4.5 \\
7.37 \\
12.6 \\
12.7 \\
\end{array}$ \\
\hline 67. Chlorsulfuron & 1.69 & 68. Oxadiazon & $\begin{array}{c}0.568 \\
0.568 \\
4.9 \\
5.49 \\
7.5\end{array}$ \\
\hline 69. Cinmethylin & $\begin{array}{c}6.6 \\
7.65 \\
12.8\end{array}$ & 70. Oxasulfuron & $\begin{array}{l}5.87 \\
8.47 \\
10.7 \\
20.0 \\
20.8 \\
29.2\end{array}$ \\
\hline 71. Clodinafop-propargyl & $\begin{array}{c}5.5 \\
28.7\end{array}$ & $\begin{array}{l}\text { 72. Oxytetracycline } \\
\text { dihydrate }\end{array}$ & 5.35 \\
\hline 73. Clofentezine & $\begin{array}{c}11.8 \\
5.17 \\
5.0 \\
10.1 \\
\end{array}$ & 74. Paclobutrazol & $\begin{array}{l}4.3 \\
7.6\end{array}$ \\
\hline 75. Clomazone & $\begin{array}{l}9.04 \\
28.3 \\
35.0\end{array}$ & 76. Parathion & $\begin{array}{l}4.88 \\
5.27 \\
11.9 \\
17.2 \\
24.0 \\
\end{array}$ \\
\hline 77. Clopyralid-olamine & $\begin{array}{l}4.87 \\
9.73\end{array}$ & 78. Parathion-methyl & $\begin{array}{l}3.61 \\
12.5\end{array}$ \\
\hline 79. Clothianidin & 19.0 & 80. Pendimethalin & $\begin{array}{l}15.0 \\
18.5\end{array}$ \\
\hline
\end{tabular}




\begin{tabular}{|c|c|c|c|c|}
\hline & & & & 37.0 \\
\hline 81. Coumaphos & $\begin{array}{c}2.87 \\
3.47 \\
3.74 \\
3.9 \\
6.5\end{array}$ & 82. & Penoxsulam & $\begin{array}{l}6.61 \\
11.0 \\
11.7\end{array}$ \\
\hline 83. Cyanazine & $\begin{array}{l}5.87 \\
5.94 \\
6.79\end{array}$ & 84. & Permethrin & $\begin{array}{l}2.15 \\
7.57 \\
29.0\end{array}$ \\
\hline 85. Cyazofamid & 9.4 & 86. & $\begin{array}{l}\text { PFOA } \\
\text { (Perfluorooctanoic } \\
\text { acid) }\end{array}$ & 2.37 \\
\hline 87. Cyclanilide & 13.0 & 88. & $\begin{array}{l}\text { PFOS } \\
\text { (Perfluorooctane } \\
\text { sulfonic acid) }\end{array}$ & $\begin{array}{l}28.8 \\
28.9 \\
38.0\end{array}$ \\
\hline 89. Cyfluthrin & $\begin{array}{l}12.3 \\
19.8 \\
25.0\end{array}$ & 90. & Phosalone & $\begin{array}{c}7.94 \\
9.9 \\
10.0 \\
11.6\end{array}$ \\
\hline 91. Cypermethrin & $\begin{array}{l}4.44 \\
10.0 \\
11.2 \\
12.7 \\
18.3 \\
4.44 \\
\end{array}$ & 92. & Piperonyl butoxide & $\begin{array}{l}0.95 \\
2.23 \\
2.97 \\
9.62 \\
15.0\end{array}$ \\
\hline 93. Cyproconazole & $\begin{array}{c}5.7 \\
7.68 \\
9.77 \\
23.0\end{array}$ & 94. & Pirimicarb & 6.5 \\
\hline 95. Cyprodinil & $\begin{array}{l}28.8 \\
30.0 \\
48.0\end{array}$ & 96. & Pirimiphos-methyl & $\begin{array}{c}5.24 \\
9.4 \\
10.6 \\
12.0\end{array}$ \\
\hline 97. Cyromazine & 5.06 & 98. & Prallethrin & $\begin{array}{c}3.56 \\
3.6 \\
6.53 \\
14.6 \\
20.0 \\
25.0\end{array}$ \\
\hline 99. DBP (Dibutyl phthalate) & 4.17 & 100. & Prochloraz & $\begin{array}{c}3.6 \\
5.0 \\
6.81\end{array}$ \\
\hline $101 \begin{array}{l}\text { DEHP (Diethylhexyl } \\
\text { phthalate) }\end{array}$ & $\begin{array}{l}20.8 \\
38.0\end{array}$ & 102. & Prodiamine & $\begin{array}{l}0.494 \\
5.65\end{array}$ \\
\hline
\end{tabular}




\begin{tabular}{|c|c|c|c|}
\hline & & & $\begin{array}{c}5.7 \\
13.6\end{array}$ \\
\hline 103 Diazinon & $\begin{array}{c}0.532 \\
4.18 \\
4.63 \\
33.0\end{array}$ & 104. Profenofos & $\begin{array}{c}5.0 \\
6.73 \\
8.97 \\
27.0\end{array}$ \\
\hline 105 Diazoxon & $\begin{array}{l}9.92 \\
29.6\end{array}$ & 106. Prometon & $\begin{array}{l}3.05 \\
4.85 \\
11.1\end{array}$ \\
\hline 107 Dichlobenil & $\begin{array}{l}0.408 \\
58.0\end{array}$ & 108. Prometryn & $\begin{array}{l}13.0 \\
25.0 \\
36.0\end{array}$ \\
\hline 109 Dichloran & 6.07 & 110. Prometryn & $\begin{array}{l}6.98 \\
7.19\end{array}$ \\
\hline 111 Diclofop-methyl & 10.3 & 112. Propanil & 12.4 \\
\hline 113 Diclosulam & $\begin{array}{c}5.97 \\
8.6 \\
34.0\end{array}$ & 114. Propargite & $\begin{array}{l}1.59 \\
20.0\end{array}$ \\
\hline 115 Dicofol & $\begin{array}{c}5.87 \\
6.9 \\
13.6\end{array}$ & 116. Propazine & $\begin{array}{c}5.66 \\
7.11 \\
7.8 \\
34.0 \\
\end{array}$ \\
\hline 117 Diethyltoluamide & $\begin{array}{l}4.62 \\
11.1 \\
12.4\end{array}$ & 118. Propetamphos & $\begin{array}{c}1.03 \\
3.17 \\
4.91 \\
7.1 \\
19.1 \\
46.0\end{array}$ \\
\hline 119 Dimethenamid & $\begin{array}{l}1.42 \\
5.32 \\
6.85 \\
6.19 \\
39.0 \\
\end{array}$ & 120. Propiconazole & $\begin{array}{c}0.533 \\
2.96 \\
14.0\end{array}$ \\
\hline 121 Dimethomorph & $\begin{array}{c}3.36 \\
3.62 \\
0.503\end{array}$ & 122. Propoxur & $\begin{array}{l}7.04 \\
8.81\end{array}$ \\
\hline 123 Diniconazole & $\begin{array}{c}0.513 \\
0.612 \\
1.3 \\
2.63 \\
9.61 \\
20.0\end{array}$ & $\begin{array}{l}\text { Propoxycarbazon } \\
\text { e-sodium }\end{array}$ & 28.0 \\
\hline
\end{tabular}




\begin{tabular}{|c|c|c|c|c|}
\hline 125 & Disulfoton & $\begin{array}{l}14.8 \\
16.8 \\
26.7 \\
38.0\end{array}$ & 126. Propyzamide & $\begin{array}{c}4.01 \\
4.59 \\
5.36 \\
6.34 \\
8.7 \\
9.19 \\
23.9 \\
24.1 \\
39.0\end{array}$ \\
\hline 127 & Dithiopyr & $\begin{array}{c}0.31 \\
1.29 \\
2.3 \\
2.62 \\
30.9 \\
\end{array}$ & 128. Pymetrozine & 17.0 \\
\hline 129 & Diuron & $\begin{array}{l}5.27 \\
9.37 \\
58.0 \\
\end{array}$ & 130. Pyraclostrobin & $\begin{array}{c}4.62 \\
7.0\end{array}$ \\
\hline 131 & Emamectin benzoate & 7.1 & 132. Pyraflufen-ethyl & $\begin{array}{l}5.03 \\
7.28 \\
11.6 \\
29.0 \\
33.3\end{array}$ \\
\hline 133 & Endosulfan & $\begin{array}{l}5.15 \\
6.45 \\
8.57 \\
10.8 \\
\end{array}$ & 134. Pyrimethanil & $\begin{array}{l}6.48 \\
9.18\end{array}$ \\
\hline 135 & Esfenvalerate & $\begin{array}{c}3.37 \\
4.6 \\
8.1 \\
15.0 \\
27.0 \\
\end{array}$ & 136. Pyriproxyfen & $\begin{array}{l}8.01 \\
12.2 \\
27.8\end{array}$ \\
\hline 137 & Ethalfluralin & $\begin{array}{c}8.1 \\
5.17 \\
13.7 \\
14.7 \\
17.0 \\
\end{array}$ & $\begin{array}{l}\text { 138. Pyrithiobac- } \\
\text { sodium }\end{array}$ & $\begin{array}{l}10.9 \\
13.4\end{array}$ \\
\hline 139 & Ethametsulfuron methyl & 0.461 & 140. Quinoxyfen & 9.68 \\
\hline 141 & Ethofumesate & $\begin{array}{c}7.0 \\
10.1 \\
17.1 \\
37.0 \\
\end{array}$ & 142. Quintozene & 3.99 \\
\hline 143 & Ethoprop & $\begin{array}{l}4.43 \\
7.0\end{array}$ & 144. Resmethrin & $\begin{array}{c}4.78 \\
6.6 \\
23.0\end{array}$ \\
\hline
\end{tabular}




\begin{tabular}{|c|c|c|c|c|c|}
\hline 145 & Etoxazole & $\begin{array}{c}1.81 \\
2.23 \\
3.3 \\
4.64 \\
7.19 \\
12.0\end{array}$ & 146. & Rimsulfuron & 9.4 \\
\hline 147 & Fenamidone & 47.0 & 148. & Rotenone & $\begin{array}{c}1.5 \\
17.0\end{array}$ \\
\hline 149 & Fenamiphos & $\begin{array}{l}5.55 \\
5.77 \\
28.7 \\
14.0\end{array}$ & 150. & S-Bioallethrin & $\begin{array}{c}3.6 \\
9.7 \\
8.75 \\
13.3 \\
19.2 \\
\end{array}$ \\
\hline 151 & Fenarimol & $\begin{array}{c}0.461 \\
0.589 \\
16.0 \\
18.0 \\
20.3 \\
49.0\end{array}$ & 152. & Sethoxydim & $\begin{array}{l}5.59 \\
27.8\end{array}$ \\
\hline 153 & Fenbuconazole & $\begin{array}{c}1.06 \\
2.02 \\
5.7\end{array}$ & 154. & Spirodiclofen & $\begin{array}{c}0.43 \\
0.437 \\
25.6\end{array}$ \\
\hline 155 & Fenhexamid & $\begin{array}{c}0.0165 \\
1.9 \\
24.0\end{array}$ & 156. & Spiroxamine & $\begin{array}{c}4.3 \\
6.42 \\
6.83\end{array}$ \\
\hline 157 & Fenitrothion & $\begin{array}{l}7.39 \\
7.87 \\
47.0\end{array}$ & 158. & Sulfentrazone & $\begin{array}{l}1.61 \\
3.38 \\
7.26 \\
34.0\end{array}$ \\
\hline 159 & Fenoxaprop-ethyl & 5.52 & 160. & TCMTB & $\begin{array}{c}1.6 \\
39.0\end{array}$ \\
\hline 161 & Fenpropathrin & $\begin{array}{l}4.59 \\
4.46 \\
5.13 \\
11.0 \\
13.3 \\
\end{array}$ & 162. & Tebufenozide & $\begin{array}{c}0.972 \\
5.17 \\
6.75 \\
21.3\end{array}$ \\
\hline 163 & Fenpyroximate $(\mathrm{Z}, \mathrm{E})$ & 12.0 & 164. & Tebufenpyrad & $\begin{array}{l}6.05 \\
24.6\end{array}$ \\
\hline 165 & Fenthion & $\begin{array}{l}4.25 \\
14.7 \\
39.0\end{array}$ & 166. & Tebupirimfos & $\begin{array}{c}0.446 \\
0.558 \\
1.46 \\
3.2 \\
13.0 \\
35.0\end{array}$ \\
\hline
\end{tabular}




\begin{tabular}{|c|c|c|c|c|}
\hline 167 & Fentin & $\begin{array}{c}0.86 \\
4.0\end{array}$ & 168. Tefluthrin & $\begin{array}{c}4.5 \\
10.5 \\
\end{array}$ \\
\hline 169 & Fipronil & $\begin{array}{c}0.568 \\
0.757 \\
28.0 \\
12.6\end{array}$ & 170. Tetraconazole & $\begin{array}{c}0.495 \\
0.471 \\
18.0 \\
22.7 \\
44.0\end{array}$ \\
\hline 171 & Fluazifop-butyl & $\begin{array}{l}12.0 \\
21.0\end{array}$ & 172. Tetramethrin & $\begin{array}{l}3.63 \\
7.09 \\
18.0 \\
43.0 \\
\end{array}$ \\
\hline 173 & Fluazinam & $\begin{array}{l}0.475 \\
0.26\end{array}$ & 174. Thiacloprid & 9.55 \\
\hline 175 & Fludioxonil & $\begin{array}{l}6.97 \\
9.63 \\
16.1 \\
23.0 \\
\end{array}$ & 176. Thiamethoxam & 9.18 \\
\hline 177 & Flufenacet & $\begin{array}{l}7.59 \\
13.0 \\
14.0\end{array}$ & 178. Thiazopyr & $\begin{array}{c}0.17 \\
0.5 \\
0.547 \\
1.01 \\
12.7\end{array}$ \\
\hline 179 & Flufenpyr-ethyl & $\begin{array}{l}6.69 \\
7.86 \\
9.98\end{array}$ & 180. Thidiazuron & 5.9 \\
\hline 181 & Flumetralin & $\begin{array}{c}0.51 \\
1.35 \\
1.8 \\
3.44 \\
4.3 \\
5.6\end{array}$ & 182. Thiobencarb & $\begin{array}{l}4.47 \\
12.1 \\
25.0 \\
28.0\end{array}$ \\
\hline 183 & Flumetsulam & $\begin{array}{l}11.3 \\
15.4 \\
16.0\end{array}$ & 184. Thiodicarb & 1.1 \\
\hline 185 & Flumiclorac-pentyl & $\begin{array}{c}2.1 \\
6.37\end{array}$ & $\begin{array}{l}\text { Thiophanate- } \\
\text { methyl }\end{array}$ & $\begin{array}{l}4.89 \\
5.09 \\
8.36 \\
48.0\end{array}$ \\
\hline 187 & Flumioxazin & 4.77 & 188. Thiram & 12.0 \\
\hline 189 & Fluometuron & $\begin{array}{l}10.2 \\
0.42\end{array}$ & 190. Tralkoxydim & $\begin{array}{l}5.84 \\
5.97 \\
14.6\end{array}$ \\
\hline 191 & Fluoxastrobin & 0.27 & 192. Tri-allate & 5.61 \\
\hline
\end{tabular}




\begin{tabular}{|c|c|c|c|}
\hline & $\begin{array}{l}0.475 \\
12.0\end{array}$ & & $\begin{array}{c}7.08 \\
9.7 \\
25.0 \\
\end{array}$ \\
\hline 193 Flusilazole & $\begin{array}{l}0.62 \\
36.0\end{array}$ & 194. Triadimefon & $\begin{array}{c}5.82 \\
5.67 \\
7.6 \\
26.0 \\
\end{array}$ \\
\hline 195 Fluthiacet-methyl & $\begin{array}{l}2.43 \\
4.79 \\
5.32 \\
53.0\end{array}$ & 196. Triadimenol & $\begin{array}{c}0.408 \\
2.39 \\
3.62 \\
4.4 \\
7.33\end{array}$ \\
\hline 197 Flutolanil & $\begin{array}{c}7.1 \\
12.1 \\
12.8 \\
34.0 \\
\end{array}$ & 198. Triasulfuron & $\begin{array}{l}4.41 \\
5.91 \\
22.0\end{array}$ \\
\hline 199 Folpet & 8.2 & 200. Tribufos & $\begin{array}{c}0.523 \\
11.1 \\
12.5 \\
23.0 \\
40.0\end{array}$ \\
\hline 201 Forchlorfenuron & 28.2 & 202. Triclosan & $\begin{array}{l}4.39 \\
13.0\end{array}$ \\
\hline 203 Fosthiazate & $\begin{array}{l}10.0 \\
10.6 \\
12.2 \\
12.7 \\
49.0\end{array}$ & 204. Trifloxystrobin & $\begin{array}{l}11.8 \\
12.6 \\
60.0\end{array}$ \\
\hline 205 Halosulfuron-methyl & $\begin{array}{l}4.54 \\
7.12 \\
\end{array}$ & $\begin{array}{l}\text { 206. } \begin{array}{l}\text { Trifloxysulfuron- } \\
\text { sodium }\end{array} \\
\end{array}$ & 7.44 \\
\hline 207 Hexaconazole & $\begin{array}{l}3.37 \\
5.33 \\
31.2 \\
49.0\end{array}$ & 208. Triflumizole & $\begin{array}{c}0.46 \\
0.534 \\
0.764 \\
32.0 \\
38.0\end{array}$ \\
\hline 209 Hexazinone & $\begin{array}{l}4.37 \\
8.64\end{array}$ & 210. Trifluralin & $\begin{array}{l}3.31 \\
11.0 \\
11.6 \\
14.0 \\
28.0 \\
\end{array}$ \\
\hline 211 Hexythiazox & $\begin{array}{c}3.2 \\
3.93 \\
8.5 \\
18.6\end{array}$ & $\begin{array}{l}\text { Triflusulfuron- } \\
\text { methyl }\end{array}$ & $\begin{array}{l}11.8 \\
34.0\end{array}$ \\
\hline
\end{tabular}




\begin{tabular}{lcccc}
\hline & & & 1.56 \\
213 & 13.0 & 214. & Triticonazole & 4.09 \\
& 23.0 & & 4.67 \\
& & & 10.0 \\
\hline 215 Icaridin & 6.82 & 216. Vinclozolin & 6.7 \\
\hline \multirow{2}{*}{217 Imazalil } & 0.588 & \multirow{2}{*}{218. Zoxamide } & 2.2 \\
& 0.1 & 4.87 \\
\hline \multirow{2}{*}{219 Imazapic } & 36.5 & & 7.55 \\
& 1.13 & & \\
\hline
\end{tabular}

Chemicals are arranged in alphabetic order. 


\title{
CURRICULUM VITAE
}

\author{
LAILA AL-ERYANI
}

Date of birth: August 01 1986, Sana'a, Yemen

Email address: laaler01@cardmail.louisville.edu

\section{EDUCATION}

Master Of Science, Pharmacology \& Toxicology

University Of Louisville

2014 (Anticipated)

Bachelor of Pharmacy, Sana'a University

July 2010

\section{AWARDS}

The Fulbright award for Foreign Student to pursue graduate studies 2012 in the U.S.A.

\section{ABSTRACTS}

1. Data Mining For Pesticides And Environmental Chemicals Associated With NAFLD. L. AI-Eryani, B. Wahlang, H.B. Clair, J. J. Guardiola, K.C. Falkner, R.A. Prough and M. Cave-AASLD (2013).

2. Database Mining For Pregnane Xenobiotic Receptor (PXR) Ligands Using ToxCast Database And PXR Activation By Organochlorine Pesticides. L. AI- 
Eryani, B. Wahlang, H.B. Clair, J. J. Guardiola, K.C. Falkner, R.A. Prough and M. Cave-AASLD (2013).

3. Identification Of Xenobiotic Receptor Agonists Which Could Contribute To Nonalcoholic Fatty Liver Disease - L. Al-Eryani, B. Wahlang, H.B. Clair, J. J. Guardiola, K.C. Falkner, R.A. Prough, J.C. States and M. Cave - Research Of Louisville, University Of Louisville (2013).

4. Hepatic Receptor Activation By Polychlorinated Biphenyls - Implications For Xenobiotic/Energy Metabolism And Nonalcoholic Fatty Liver Disease. B. Wahlang, K.C. Falkner, H.B. Clair, L. Al-Eryani, J.J. Guardiola, R.A. Prough, and M. Cave-AASLD (2013).

5. Identification Of Environmental Chemicals Which Could Contribute To Nonalcoholic Fatty Liver Disease By Nuclear Receptor Activation. L. AlEryani, B. Wahlang, K.C. Falkner, H.B. Clair, R.A. Prough, J.C. States and M. Cave- SOT (2014).

6. Aroclor 1260 Exposure Worsens Hepatic And Systemic Inflammation In An Animal Model Of Diet-Induced Obesity And Nonalcoholic Fatty Liver Disease. B. Wahlang, M. Song, J. Beier, L. Al-Eryani, H.B. Clair, J.J. Guardiola, K.C. Falkner, R.A. Prough, and M. Cave-AASLD (2013). 


\section{PUBLICATIONS}

1. Human Receptor Activation By Aroclor 1260, A Polychlorinated Biphenyl Mixture. Banrida Wahlang, K. Cameron Falkner, Heather B. Clair, Laila A. AlEryani, Russell A. Prough, J. Christopher States, Denise M. Coslo, Curtis J. Omiecinski and Matt Cave.

2. Organochlorine Pesticide, Lead, and Mercury Exposures Are Associated with Liver Disease In The United States General Adult Population. Matt Cave, Savitri Appana, Laila Al-Eryani, Mihir Patel, Keith Cameron Falkner, Craig J. McClain, Guy Brock. (Under review for publication)

3. Identification Of Environmental Chemicals Associated With The Development Of Toxicant Associated Steatohepatitis In Rodents. Laila Al-Eryani, Banrida Wahlang, K.C. Falkner, J. J. Guardiola, H.B. Clair, R.A. Prough and M. Cave. (Under review for publication)

PROFESSIONAL MEMBERSHIPS/POSITIONS

Member, Ohio Valley Chapter of the Society of Toxicology (OVSOT)

2013- Present

Member, Society of Toxicology (SOT)

2014- Present 